\title{
Solar PV Minigrid Technology: Peak Shaving Analysis in the East African Community Countries
}

\author{
Jeanne Paula Ihirwe $\mathbb{D}^{1},{ }^{1}$ Zibiao Li $\mathbb{D},{ }^{1}$ Keyuan Sun $\left(\mathbb{D},{ }^{1}\right.$ Samuel Bimenyimana $\mathbb{D}^{2,3}$ \\ Chen Wang $\mathbb{D}^{2},{ }^{2}$ Godwin Norense Osarumwense Asemota $\mathbb{D}^{4,5}$ Aphrodis Nduwamungu ${ }^{4}{ }^{4}$ \\ and Cicilia Kemunto Mesa ${ }^{(1 D}{ }^{6}$ \\ ${ }^{1}$ Department of Economics and Management, Hebei University of Technology, Tianjin, China \\ ${ }^{2}$ Huaqiao University, Intelligence and Automation in Construction Provincial Higher-Educational Engineering Research Centre, \\ 361021 Xiamen, China \\ ${ }^{3}$ Hello Renewables Ltd., Kigali, Rwanda \\ ${ }^{4}$ University of Rwanda, African Centre of Excellence in Energy for Sustainable Development, Kigali 4285, Rwanda \\ ${ }^{5}$ Morayo College, Nairobi, Kenya \\ ${ }^{6}$ Kenya Industrial Research and Development Institute, Nairobi, Kenya
}

Correspondence should be addressed to Zibiao Li; lizibiao2008@126.com

Received 27 January 2021; Revised 14 April 2021; Accepted 13 May 2021; Published 4 June 2021

Academic Editor: Evgeny Solomin

Copyright (C) 2021 Jeanne Paula Ihirwe et al. This is an open access article distributed under the Creative Commons Attribution License, which permits unrestricted use, distribution, and reproduction in any medium, provided the original work is properly cited.

\begin{abstract}
Solar PV research in East Africa has concentrated on solar home systems (SHS) in each country. However, several other fundamental advances in the solar photovoltaic (PV) industry have emerged, and the developments have seen the sector experienced significant growth and diversification of models, regulation, and financing. This paper begins with an extensive narrative on the solar PV outlook of each of the six countries studied. A solar PV minigrid was also simulated using HOMER software with a critical load of $2800.0 \mathrm{kWh} /$ day in order to analyze the peak shaving capability and assess the affordability of the solar PV microgrid having commercial and industrial loads. The regional overview of the efforts was identified, followed by a description of the models, payment methods, and barriers encountered collectively. The lessons from this research suggest that there is a vast potential for solar PV micro and minigrid deployment in the region with a population of over 100 million people lacking access to electricity by the end of 2019. It shows that solar PV minigrid deployment in East Africa is still at a nascent phase. Also, minigrid developers face several challenges operating in rural areas. While solar PV minigrids remain fairly nascent in the East Africa region, the technology is gaining traction, a development that indicates budding confidence in the solar PV minigrid technology. This study identifies that (1) with large critical loads (industrial and commercial), solar PV minigrid can still contribute to affordable electricity through peak shaving, except Tanzania; (2) solar PV minigrid projects are largely dependent on donor financing, require vast financial diversity to get off the ground, and offer consistent service; (3) Governments support in the form of National electrification strategies, policies, and regulation are key ingredients for realizing the electrification of rural populations through minigrids; (4) hybrid minigrids and power demand creation have emerged as an approach that ensures sustainability or profitability for the operating solar minigrid firms. Overall, government policy and regulation, funding, and financial sustainability remain the major hurdles to minigrid uptake in the region.
\end{abstract}

\section{Introduction}

The African continent basks on exceptional solar radiations globally, receiving a minimum of $4 \mathrm{kWh} / \mathrm{m}^{2} /$ day as the continent lies within the Sunbelt region. The dissemination of modern energy technologies (MET) in African countries remains quite low with the penetration rate of solar technology rising from 1\% in 2010 to $4 \%$ in 2013 [1]. Sub-Sahara Africa remains prevalent in electricity access deficit where 625 million people live without access [2, 3]. Eighty percent 
of the affected communities stay in the countryside where the cost of grid connection is deemed exorbitant by national utilities. Burundi, one of the 20 countries with the lowest electrification rates according to the IEA electrification rates in 2017 [4], is lodged in the region. Advancements in the electrification of rural areas have been limited most informal households are still connected through flimsy distribution networks with urban access rates significantly higher than rural rates. Given the situation, off-grid solutions are indispensable; these include solar home systems for lighting and heating and increasingly now, micro and minigrids [4].

With the aforementioned concept, there is a huge quantity of solar energy potential which has not yet been well exploited, and research is among the key pillars to the development of productive technologies once their results are feasible and implementable. The research in this paper is intended to give an extensive narrative review on solar PV outlook of each of the six countries of the East African Community (EAC) which are also members of Sub-Saharan Africa; study analysis on how a grid-connected solar PV minigrid with its storage contribute to peak shaving of a critical load (commercial or industrial) with an average of $2800.0 \mathrm{kWh} /$ day and $200.0 \mathrm{~kW}$ daily peak load. Not only these, but the paper also intends to give a regional overview of the efforts identified followed by a description of models, payment methods, and barriers encountered collectively and provide concluding remarks upon the case already built.

\section{Literature Search}

The International Energy Agency (IEA) indicates that the population with access to electricity in 2015 was $1.0 \%$ in South Sudan, 9.1\% in Burundi, 18.5\% in Uganda, 26.4\% in Rwanda, $30.0 \%$ in Tanzania, and $41.2 \%$ in Kenya against $84.5 \%$ in the world. By the end of 2019, South Sudan was at $1.1 \%, 10.9 \%$ in Burundi, $28.9 \%$ in Uganda, 39.5\% in Tanzania, $52.6 \%$ in Rwanda, and $84.5 \%$ in Kenya against $90.0 \%$ in the world [5]. The transformation has partly been achieved through the deployment of solar PV projects both off and grid-connected. The projects are being funded by major international financiers, governments, donors, and a few coming to being through private firms in the energy business $[6,7]$.

Tanzania and Uganda are leading with the highest population without access to electricity at 36 and 25 million, respectively. Rwanda, South Sudan, and Burundi are the countries with the least populations without access in that order at populations of 10 million and below.

Kenya has an access deficit of 13 million people [5]. As it can be seen from Figure 1[4], Kenya is leading in electrification efforts at $84.5 \%$ followed by Rwanda at $52.6 \%$, the rest are below $50.0 \%$.

Minigrids have become a significant solution in rural electrification, being considered next to large-scale grid extension and solar home systems (SHS). The International Energy Agency (IEA) submits that globally about $70.0 \%$ of rural areas are unsuitable for central grid electricity. Micro and minigrids utilizing renewable energy are pertinent in achieving universal electrification $[4,8]$. A minigrid is also

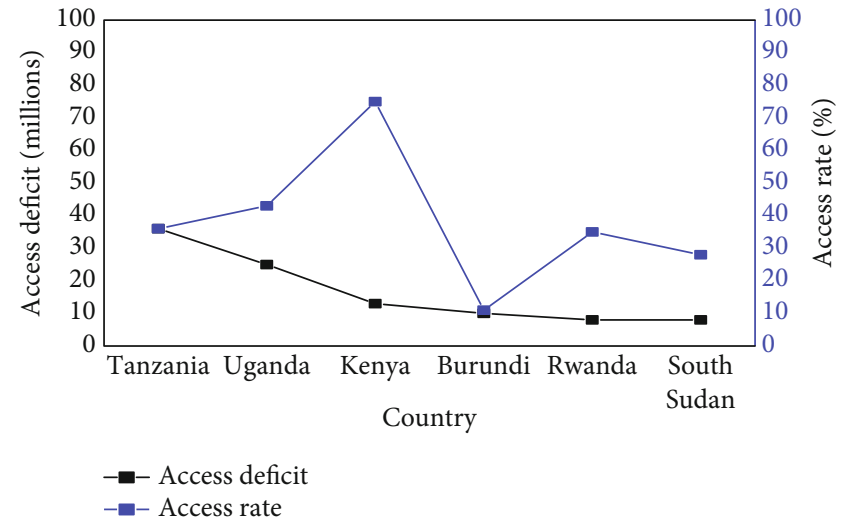

Figure 1: Access deficit population in millions and access rate percentage.

known as a nano or microgrid depending on the size of the population served is a power plant with generation, transmission, and distribution capacity but operating within a specific geographical location, serving specific customers. They can be connected to the central grid or operate independently [9]. Currently, there are three minigrid generations. Firstgeneration minigrids that normally utilize diesel as an energy resource, second-generation minigrids that utilize hydro as an energy resource, and third-generation utilize renewable energy resources like solar and biomass. The third generation is also described as renewable-hybrid minigrids, and the term renewable-hybrid could be used to refer to two different systems. It could mean a minigrid setup that utilizes multiple energy resources with at least one being renewable or it could also mean a minigrid that combines power generation from a renewable energy resource and has storage batteries for back up when generation is not viable [10]. In this research, the term will also mean either of the two meanings. This research is focused primarily on renewable hybrid minigrids in the six East African nations as they are shown in Figure 2.

Solar hybrid minigrids are the fastest-growing segment globally. While $32.0 \%$ of installed minigrids are either powered by fossil fuels or hydro, PV technology is dominantly being used in minigrid installations currently. Modern minigrids installations presently combine energy storage with PV while hybridizing old fossil fuel minigrids by adding PV resources. In recent years, with the evolution of the solar hybrid minigrid market, international corporates have also joined their ranks offering electrochemical storage systems like batteries, uninterrupted power supply (UPS), and remote-control technologies [11].

Renewable energy is maturing as a global resource, and the sector had its most significant growth in the year 2015. A combination of wind power and solar PV constituted more than $75.0 \%$ of new global energy installations in 2015, trailed by hydropower. Renewable power installations are leading compared to combined new fossil fuel installations by capacity annually. As of 2015, renewable energy installations could supply a quarter of the world's universal electricity [12]. Advances in all components of renewable energy resources are important; however, this study is most concerned with the evolution of the solar PV minigrid segment. Solar PV is 


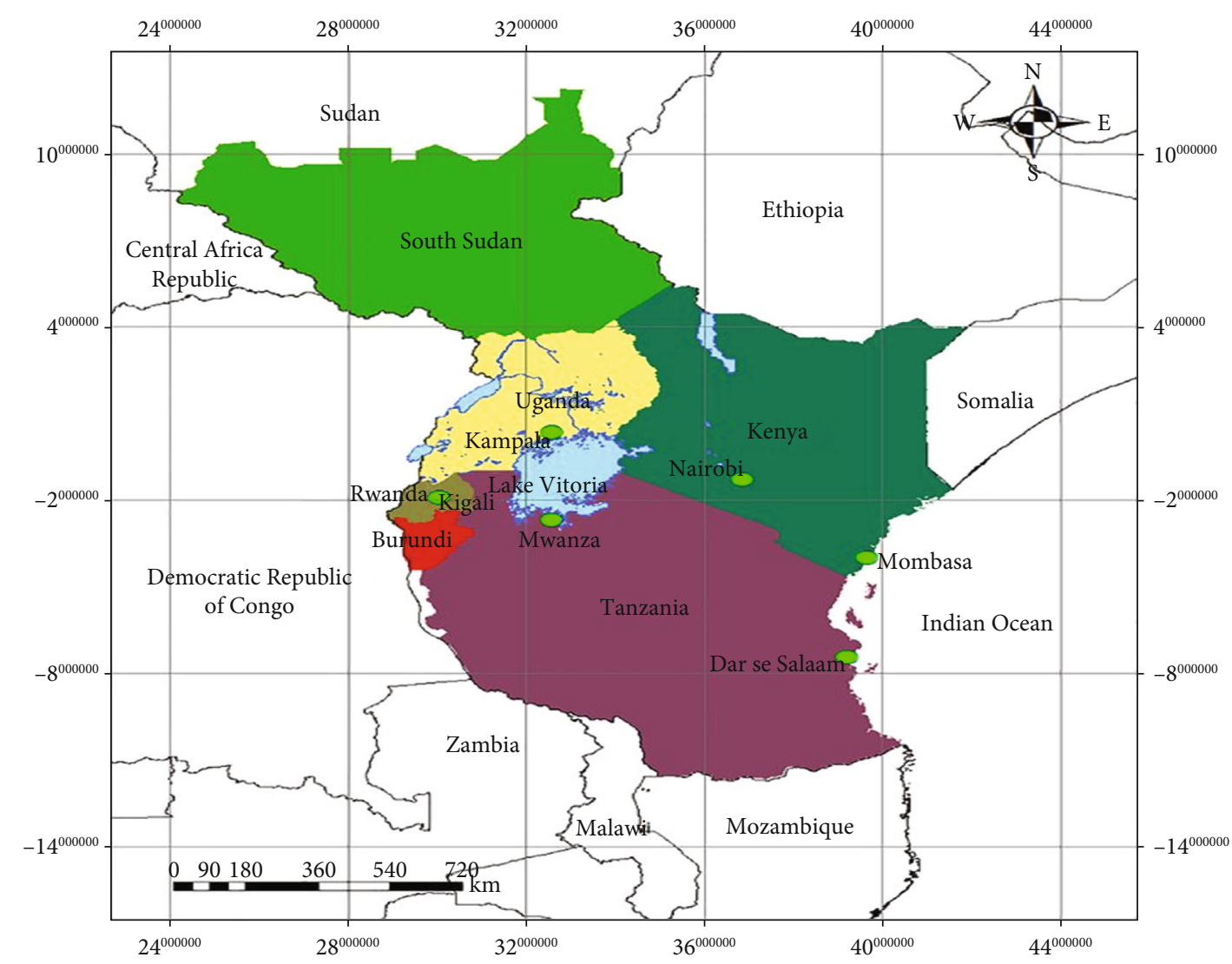

Figure 2: The six East Africa Community countries (Source: Telesphore Kabera).

remarkable for its ease of installation and operation at diverse scales. Recently, solar PV prices have reduced significantly, and this is attributed to the confluence of increase in global production, research and development, and a positive deployment environment [13].

\section{Methodology}

This paper is based on HOMER (Hybrid Optimization Model for Multiple Energy Resources) software simulations and a desk study encompassing multiple literature sources complemented by data collected from relevant minigrid developers and market players. The review of existing literature includes 31 existing reports from major sector players, 16 peer-reviewed research publications, 26 web pages including government websites, 14 government, legal documents, and legitimate online databases. The gathered information and data were used to examine the progress of the minigrids utilizing solar PV in the six East African countries, policy and regulations, institutional framework, payment methods, market potential, and existing challenges. Not only this, a model of peak shaving was adopted from HOMER software (model with critical load), and simulations were carried out specifically for each country member of the EAC to analyze and assess the capability of a grid-connected solar PV minigrid and its storage in contributing to the load peak shaving condition as shown in Figure 3. Electricity tariff prices were from different databases (references), and others were col-

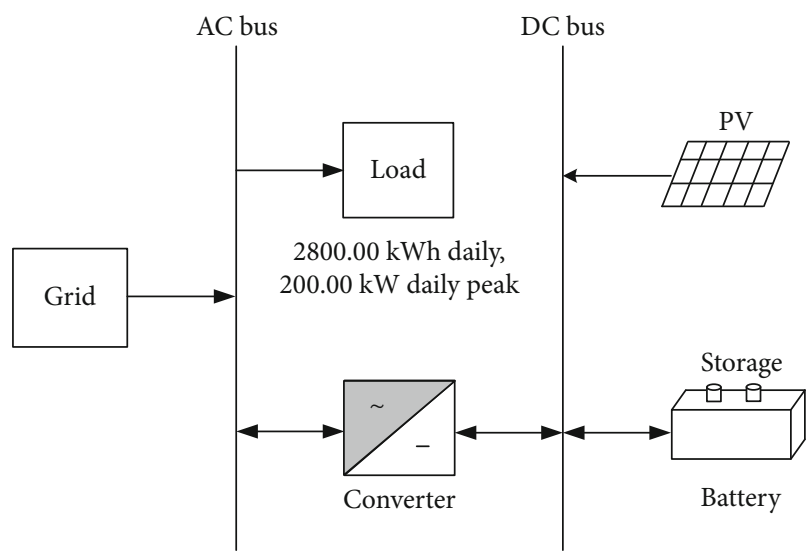

FIgURE 3: Schematic diagram of the HOMER model.

lected through voice-to-voice interview with local citizens in those countries. This critical load structure (adopted from HOMER software) was used as research object in six EAC countries with different locations such as at this load structure was as research object in other five EAC countries with different locations such as at Jinja Road, Kampala, Uganda $\left(0^{\circ} 20.2^{\prime} \mathrm{N}, 32^{\circ} 37.5^{\prime} \mathrm{E}\right)$ for Uganda (location for Uganda Industrial Research Institute), at Kimweri Ave, Dar es Salaam, Tanzania $\left(6^{\circ} 45.9^{\prime} \mathrm{S}, 39^{\circ} 16.2^{\prime} \mathrm{E}\right)$ for Tanzania (location for Tanzania Industrial Research and Development Organization), at South C Nairobi KE, Nairobi, Kenya 
$\left(1^{\circ} 19.4^{\prime} \mathrm{S}, 36^{\circ} 49.9^{\prime} \mathrm{E}\right)$ for Kenya (location for Kenya industrial research and development institute), at Ayod, South Sudan $\left(8^{\circ} 22.8^{\prime} \mathrm{N}, 30^{\circ} 42.7^{\prime} \mathrm{E}\right)$ for South Sudan (location for the SUDD Institute), at Boulevard de l'Indépendance, Bujumbura, Burundi $\left(3^{\circ} 23.1^{\prime} \mathrm{S}, 29^{\circ} 22.4^{\prime} \mathrm{E}\right)$ for Burundi (location for Institute Statistics and Studies Economic Du Burundi), and at 2 KG 2 Ave, Kigali, Rwanda ( $\left.1^{\circ} 57.1^{\prime} \mathrm{S}, 30^{\circ} 5.1^{\prime} \mathrm{E}\right)$ for Rwanda (location for Institute of Policy Analysis and Research).

\section{Solar Minigrid Developments in the East Africa Region}

\subsection{Narrative Review and Simulation Results Analysis}

4.1.1. Uganda. Uganda's yearly sunshine hours range from 1753 to 2264 with global horizontal radiation of $4.8-$ $6.2 \mathrm{kWh} / \mathrm{m}^{2}$ per day. The northeast experiences the highest insolation. Annually, the solar irradiation ranges from $1,825.0 \mathrm{kWh} / \mathrm{m}^{2}$ to $2,500.0 \mathrm{kWh} / \mathrm{m}^{2}$ [14]. However, the use of solar energy is still relatively low in Uganda and projects barely get off the ground without significant donor and government support. Uganda is reported to have a capacity of $56.8 \mathrm{MW}$ from 34 installed minigrids [11], 34.0\% of them being hydro minigrid power plants as shown in Figure 4. Forty percent of these are either solar PV (27\%) or solar PV hybrid (13\%) minigrids as of the end of 2019.

The component of solar minigrid plants tripled in 2015 and has not changed significantly since then. There are two-megawatt scale solar PV plants in Uganda with each having a capacity of $10.0 \mathrm{MW}$ inaugurated in 2016 and 2017 , respectively $[15,16]$. Few other solar PV minigrids with a capacity totaling $30.0 \mathrm{MW}$ are either on proposal or development stage [16-18]. The trend on general solar PV technology deployment is unlike the minigrid component trend as shown in Figure 4. Since 2017, there has been a tremendous increase in installations, the deployment of solar PV almost doubled in both 2017 and 2019 suggesting an aggressive growth due to the acquisition of stand-alone solar home systems compared to solar minigrids.

Uganda is the second highest with solar PV installation of 82.16 MW after Kenya in the countries considered in this study (Figure 5). Uganda has installed a significant number of megawatt-scale solar PV plants and has several plans to continue with this trend. The situation can be attributed to several favorable regulations. Presently, projects in Uganda are regulated based on their capacity. Minigrids producing 2.0 MW or more are under the same regulations as independent power producers (IPPs) in the acquisition of the license, approval of tariffs, and technical standards. Minigrids producing less than 2.0MW of power are exempt from licensing but undergo a process of developing a Memorandum of Understanding (MoU) with the Electricity Regulatory Authority (ERA) [11]. After approving the licenseexempted minigrids, the Rural Electrification Agency (REA) provides distribution infrastructure, connecting households without charge. Developers are therefore left to provide generation capacity and meet the cost of operations

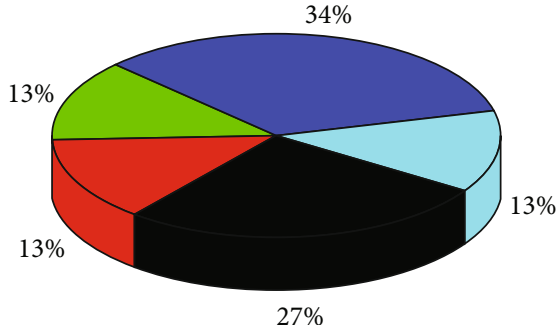

$27 \%$

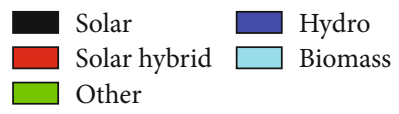

FIgURe 4: Minigrids in Uganda by resource utilized. (Source: Bloomberg NEF, GIZ, Carbontrust, CLUB-ER, Surveyed developers).

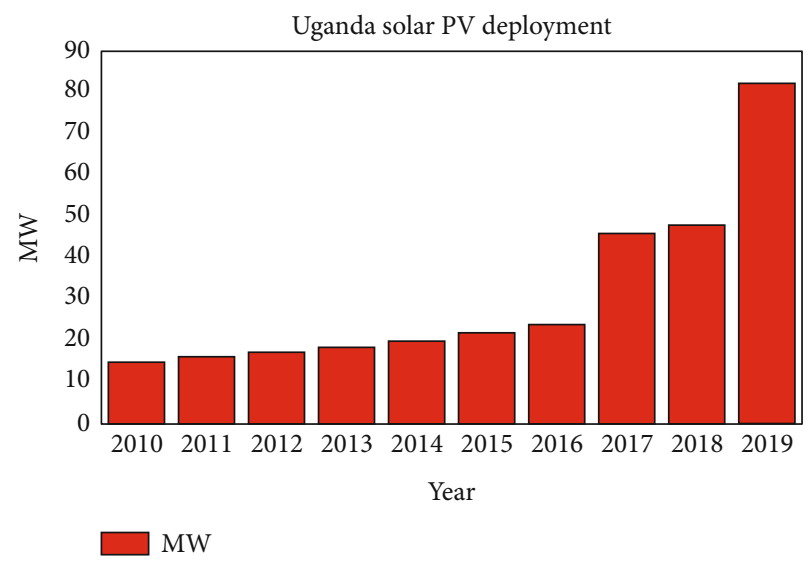

FIgure 5: Solar PV deployment trends in Uganda by IRENA.

and maintenance for the plant. REA installs grid-compliant distribution infrastructure to avoid the risk of grid arrival going forward, and this effectively represents nearly $30.0 \%$ of each minigrid project $[11,19]$. Table 1 describes the institutions involved in the energy sector in Uganda.

As shown in Figure 6, sixty-seven percent of minigrids in Uganda are owned privately, twenty-seven percent are community-owned, and six percent are developed under the public-private partnership.

Uganda's electricity connection policy approved in January 2018 works towards $30.0 \%$ electrification by $202060.0 \%$ by 2027 and $80.0 \%$ by 2040 [20]. Currently, Uganda's electrification stands at $28.9 \%$ [22]. Going forward, immense minigrid development opportunities arise over the several habitable islands on Lake Victoria under Uganda's jurisdiction where the main grid extension is not practical. In 2018, Uganda's regulatory authority (REA) embarked on a planning exercise and identified 320 locations seemly for minigrid deployment. When developed the minigrids will supply electricity to 70,000 households. Several bundled tender schemes for minigrid development are also underway since 2018 [11, 23]. Figure 7 depicts the monthly solar global horizontal irradiation index (GHI) for Uganda. The GHI slightly rose from $4.894 \mathrm{kWh} / \mathrm{m}^{2} /$ day in January to $4.923 \mathrm{kWh} / \mathrm{m}^{2} /$ day in February, declined unevenly to the 
TABLE 1: Institutions involved in the energy sector in Uganda.

\begin{tabular}{|c|c|c|}
\hline Institution & Mandate & Ref \\
\hline $\begin{array}{l}\text { Uganda Electricity } \\
\text { Board (UEB) }\end{array}$ & $\begin{array}{c}\text { Consists of three entities: (1) Uganda Electricity Generation Company Limited (UEGCL). } \\
\text { (2) Uganda Electricity Transmission Company Limited (UETCL). (3) Uganda Electricity } \\
\text { Distribution Company Limited (UEDCL) }\end{array}$ & {$[11]$} \\
\hline $\begin{array}{l}\text { Rural Electrification } \\
\text { Agency (REA) }\end{array}$ & $\begin{array}{l}\text { Develops and owns the distribution infrastructure of minigrids through the Rural } \\
\text { Electrification Fund. It also leases assets to private minigrid developers. }\end{array}$ & {$[20]$} \\
\hline UMEME & $\begin{array}{l}\text { Awarded a } 20 \text {-year concession for distribution and retail of power in } 2005 \text { by UEDCL. } \\
\text { UMEME was formed in } 2004 \text { and is presently doing distribution of } 98.0 \% \text { of central grid electricity. }\end{array}$ & [19] \\
\hline Eskom & $\begin{array}{l}\text { Oversees the operation and maintenance of generation assets since } 2003 \text { when UEGCL } \\
\text { subleased its generation mandate to ESKOM, a South African utility owned by the state. }\end{array}$ & {$[19$} \\
\hline $\begin{array}{l}\text { Electricity Regulatory } \\
\text { Authority (ERA) }\end{array}$ & $\begin{array}{l}\text { Main regulatory authority of Uganda's minigrids. It manages approval of licenses, tariff } \\
\text { setting, and maintains technical standards. }\end{array}$ & {$[21]$} \\
\hline
\end{tabular}

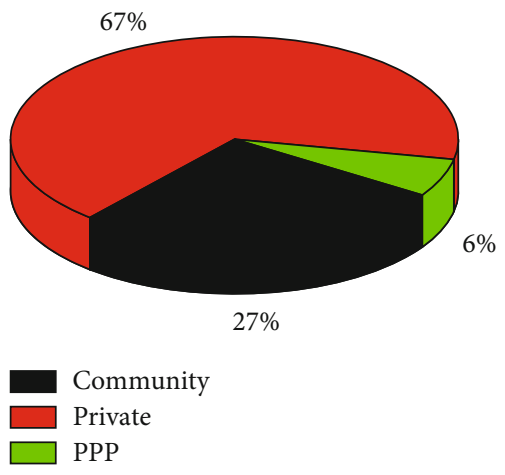

FIgURE 6: Minigrid ownership options in Uganda. Source: Bloomberg NEF, GIZ, Carbontrust, CLUB-ER, Surveyed developers.

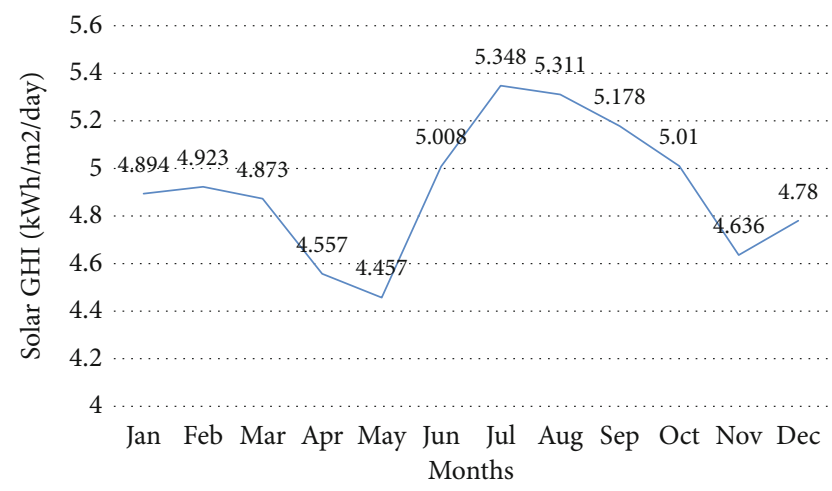

Figure 7: Monthly solar Global Horizontal Irradiation (GHI $\mathrm{kWh} / \mathrm{m}^{2} /$ day) for Uganda.

lowest point of $4.457 \mathrm{kWh} / \mathrm{m}^{2} /$ day in May, and rose sharply to $5.348 \mathrm{kWh} / \mathrm{m}^{2} /$ day peak in July. The GHI for Uganda decreased to $4.636 \mathrm{kWh} / \mathrm{m}^{2} /$ day in November and rose slightly to $4.78 \mathrm{kWh} / \mathrm{m}^{2} /$ day in December.

Figure 8 indicates the monthly clearness index (CI) for Uganda. The CI slightly decreased from 0.488 in January to 0.446 in April and rose to 0.46 in May, respectively. The CI gently rose to 0.565 in July (peak) and gradually declined to 0.461 in November and rose to 0.484 in December.

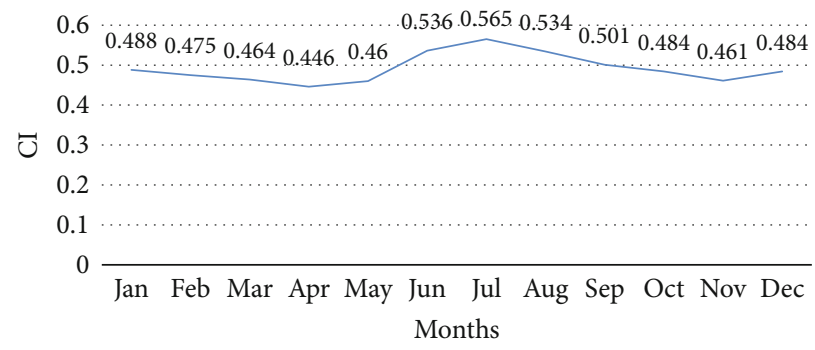

Figure 8: Monthly clearness index (CI) for Uganda.

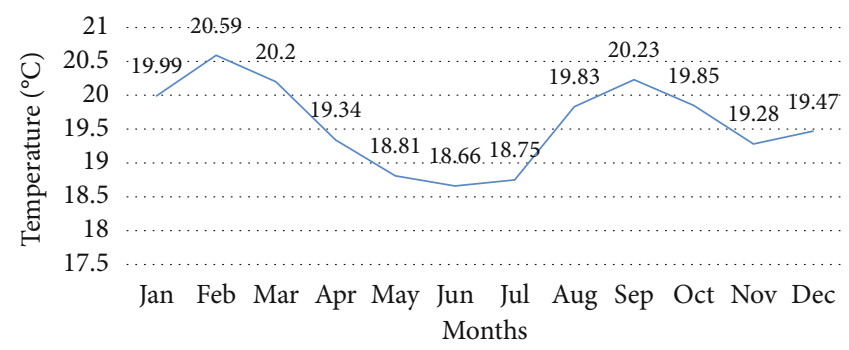

Figure 9: Monthly temperature variation $\left({ }^{\circ} \mathrm{C}\right)$ for Uganda.

Figure 9 shows the monthly temperature variation for Uganda. The temperature rose from $19.99^{\circ} \mathrm{C}$ in January to $20.59^{\circ} \mathrm{C}$ in February (peak). It gradually declined to the least $18.66^{\circ} \mathrm{C}$ in June and rose to $18.75^{\circ} \mathrm{C}$ in July. The temperature rose to $20.23^{\circ} \mathrm{C}$ in September and gradually decline to $19.28^{\circ} \mathrm{C}$ in November and rose to $19.47^{\circ} \mathrm{C}$ in December.

Figure 10 reflects the cumulative cash flows for the current and proposed power systems over the life of the projects for Uganda. The cash flow for the current power system at the inception was around US\$-184,931.51, and the cash flow rose steadily to US $\$ 1,800,000.00$ in 15 years, where it had the same cash flow as the proposed power system. The cash flow for the current power system rose to about US\$2,459,589.04 at the $25^{\text {th }}$ life span. Furthermore, the cash flow for the proposed power system rose gradually from US $\$ 900,000.00$ at inception to US\$2,145,205.48 in year 25, which was the end of the economic life of the proposed power system. Comparing the cumulative cash flows of the two power systems, using 


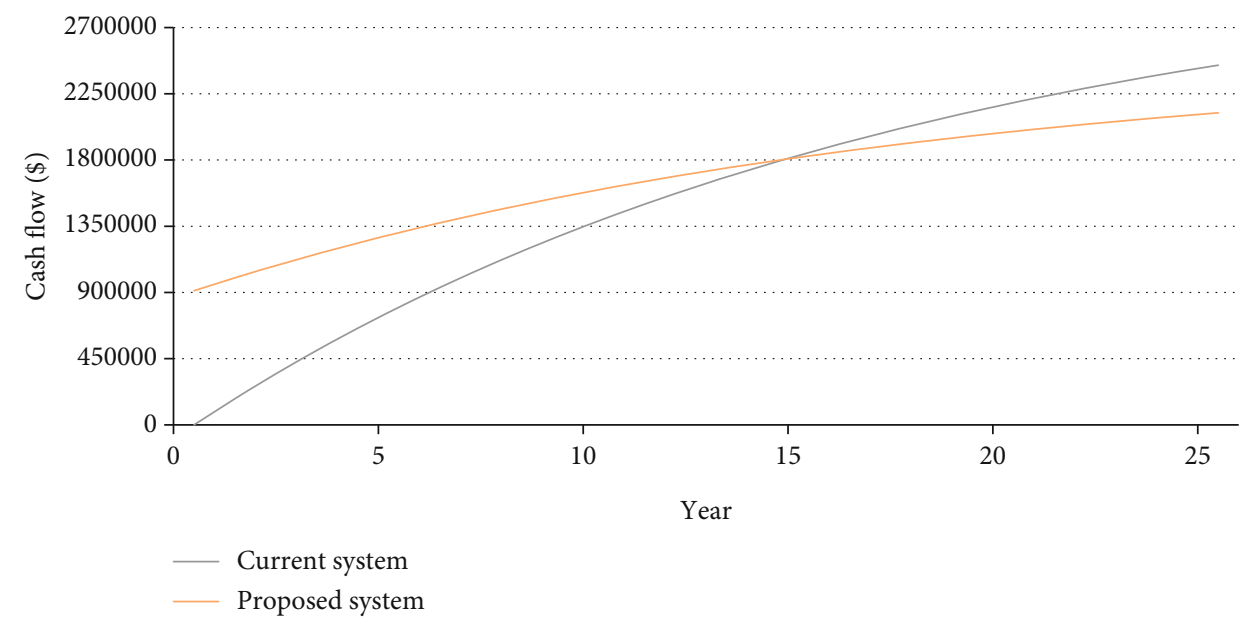

FIgURE 10: Cumulative cash flows over project lifetime for the current and proposed systems for Uganda.

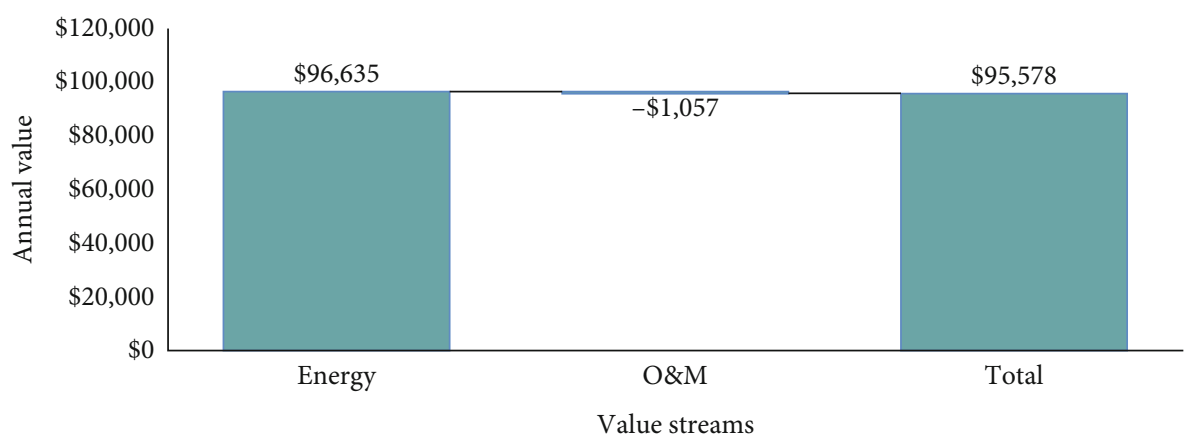

FIGURE 11: Categorized annual savings for the proposed system for Uganda.

the approximate area under their respective cash-flow curves, US $\$ 30,748,238.00$ was for the current power system while US\$38,065,068.50 was for the proposed power system. Therefore, the proposed power would generate about US\$7,316,830.50 cash flows than the current power system in Uganda.

Figure 11 indicates the categorized annual savings for the proposed power system in Uganda. The annual energy amount was US\$96,635.00, and US\$-1,057.00 was the operations and maintenance expense, while the annual energy savings was US\$96,578.00, respectively.

Figure 12 depicts the monthly utility bills for the current and proposed power systems in Uganda. The January bills for both the current and proposed power systems were US $\$ 15,965.41$ and US\$8,056.93, respectively. The February bills for both the current and proposed power systems were US\$14,571.67 and US\$7,414.05, respectively. The March bills for both the current and proposed power systems were US\$15,965.41 and US\$7,885.40, respectively. The April bills for both the Current and proposed power systems were US $\$ 15,600.04$ and US\$8,056.80, respectively. The May bills for both the current and proposed power systems were US $\$ 16,114.60$ and US $\$ 8,571.00$, respectively. The June bills for both the current and proposed power systems were US $\$ 15,600.40$ and US $\$ 7,370.20$, respectively. The July bills for both the current and proposed power systems were
US\$16,114.60 and US\$7,114.10, respectively. The August bills for both the current and proposed power systems were US\$16,114.60 and US\$7,199.80, respectively. The September bills for both the current and proposed power systems were US\$15,600.40 and US\$7,371.20, respectively. The October bills for both the current and proposed power systems were US\$16,028.90 and US\$7,714.00, respectively. The November bills for both the current and proposed power systems were US $\$ 15,600.40$ and US $\$ 8,142.50$, respectively. The December bills for both the current and proposed power systems were US\$16,114.60 and US\$8,056.80, respectively.

Table 2 shows the annual utility bills and savings by category for Uganda. The US\$189,070.00 base case consumption charge and US\$92,435.00 proposed power system consumption charge, respectively. The annual savings which is the difference between the current and proposed power systems consumption charges was US\$96,635.00.

Figure 13 reflects the electrical production capacities for both the current (grid) and proposed solar PV microgrid power systems technology in Uganda. The January power generation for both the grid and solar PV microgrid was 100.98 MWh and 48.29 MWh, respectively. The February power production for both the grid and solar PV microgrid was $89.27 \mathrm{MWh}$ and $43.90 \mathrm{MWh}$, respectively. The March power production for both the grid and solar PV microgrid was 100.0 MWh and 48.29 MWh, respectively. 


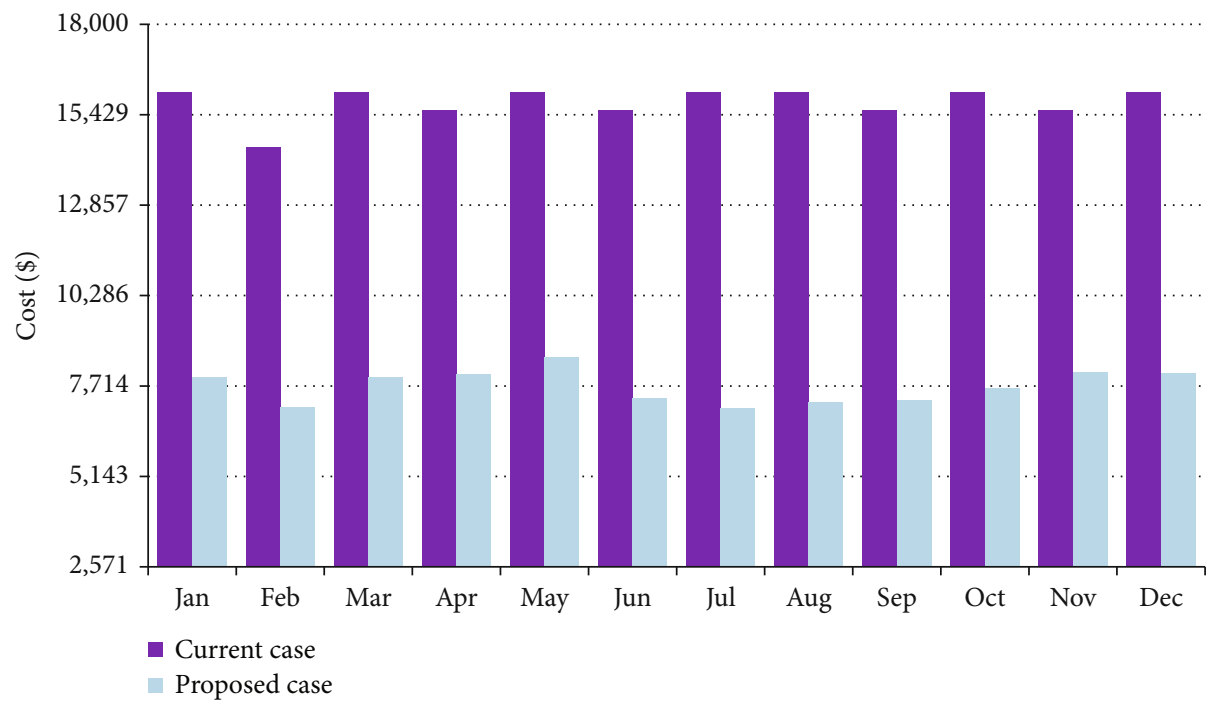

FIGURE 12: Monthly utility bills for the current and proposed systems for Uganda.

TABle 2: Annual utility bills and savings by category.

\begin{tabular}{lcc}
\hline & Consumption charge & Total \\
\hline Base case & $\$ 189,070.00$ & $\$ 189,070.00$ \\
Proposed case & $\$ 92,435.00$ & $\$ 92,435.00$ \\
Annual savings & $\$ 96,635.00$ & $\$ 96,635.00$ \\
\hline
\end{tabular}

Note: the base case is considered as the current system (grid connection) and the proposed case is the grid-connected solar PV microgrid with storage.

The April power production capacities for both the grid and solar PV microgrid were $92.20 \mathrm{MWh}$ and $42.44 \mathrm{MWh}$, respectively. The May power production capacities for both the grid and solar PV microgrid were 96.59 MWh and 43.90 MWh, respectively. The June power production capacities for both the grid and solar PV microgrid were 93.66 MWh and 46.93 MWh, respectively. The July power production capacities for both the grid and solar PV microgrid were $98.78 \mathrm{MWh}$ and $52.58 \mathrm{MWh}$, respectively. The August power production capacities for both the grid and solar PV microgrid were 100.24 MWh and 52.68 MWh, respectively. The September power production capacities for both the grid and solar PV microgrid were $98.05 \mathrm{MWh}$ and $49.76 \mathrm{MWh}$, respectively. The October power production capacities for both the grid and solar PV microgrid were 98.05 MWh and 49.76 MWh, respectively. The November power production capacities for both the grid and solar PV microgrid were 75.40 MWh and 43.79 MWh, respectively. The December power generation capacities for both the grid and solar PV microgrid were $98.78 \mathrm{MWh}$ and $46.83 \mathrm{MWh}$, respectively.

The solar PV system has a nominal capacity of $400.0 \mathrm{~kW}$, its annual production is $573619.0 \mathrm{kWh} /$ year, and the specific yield is $1434.05 \mathrm{~h} /$ year.

Table 3 depicts the project cost details for both the grid and solar PV systems for the lifetime of the projects in Uganda. The yearly project cost throughout the 25 -year economic lives of both the solar PV and grid power systems was US $\$ 1,057.00$ and US\$92,435.00, respectively.
Table 4 is the utility monthly summary for the current grid system for the whole project's economic life for Uganda. The energy purchased varied between $86,800.0 \mathrm{kWh}$ and $84,000.0 \mathrm{kWh}$ in alternate months except $78,400.0 \mathrm{kWh}$ for February. Specifically, the energy purchased was 86,800.0 kWh for January, March, May, July, August, October, and December, respectively. The energy purchase was $84,000.0 \mathrm{kWh}$ each for April, June, September, and November, respectively, and the annual energy purchase was $1,022,000.0 \mathrm{kWh}$. There was no energy sold, and the peak load was $200.0 \mathrm{~kW}$. The energy charge was each US $\$ 16,058.00$ for January, March, May, July, August, October, and December, respectively. The energy charge was each US $\$ 15,540.00$ for April, June, September, and November, respectively, while the energy charge for February was US $\$ 14,504.00$. The demand charge, fixed charge, minimum charge, and taxes were each zero, respectively. Also, the annual total energy charge was US $\$ 189,070.00$.

Table 5 indicates the utility monthly summary of the proposed power system for Uganda. The energy purchased $(\mathrm{kWh})$, energy sold $(\mathrm{kWh})$, and net energy purchased $(\mathrm{kWh})$ were each different for every month from January to December. The peak load was $200.0 \mathrm{~kW}$ every month and throughout the year. The energy charge (US\$) was equally variable every month, while each of the demand charge, fixed charge, minimum charge, and taxes was zero, respectively. The total annual energy purchase was $594,299.0 \mathrm{kWh}$, the annual energy sold was $145,918.0 \mathrm{kWh}$, and the annual net energy purchase was $448,382.0 \mathrm{kWh}$, respectively. Also, the total annual energy charge was US\$92,435.00.

4.1.2. Kenya. The electrification level in Kenya stands at $84.5 \%$ [22]. While Kenya is one of the countries with a very extensive grid network, most of the marginalized counties have not benefited from this government initiative [24]. Given this situation, several minigrid solar projects have been initiated. These minigrids are both off-grid and some are grid-connected. Despite the potential of minigrids to electrify 


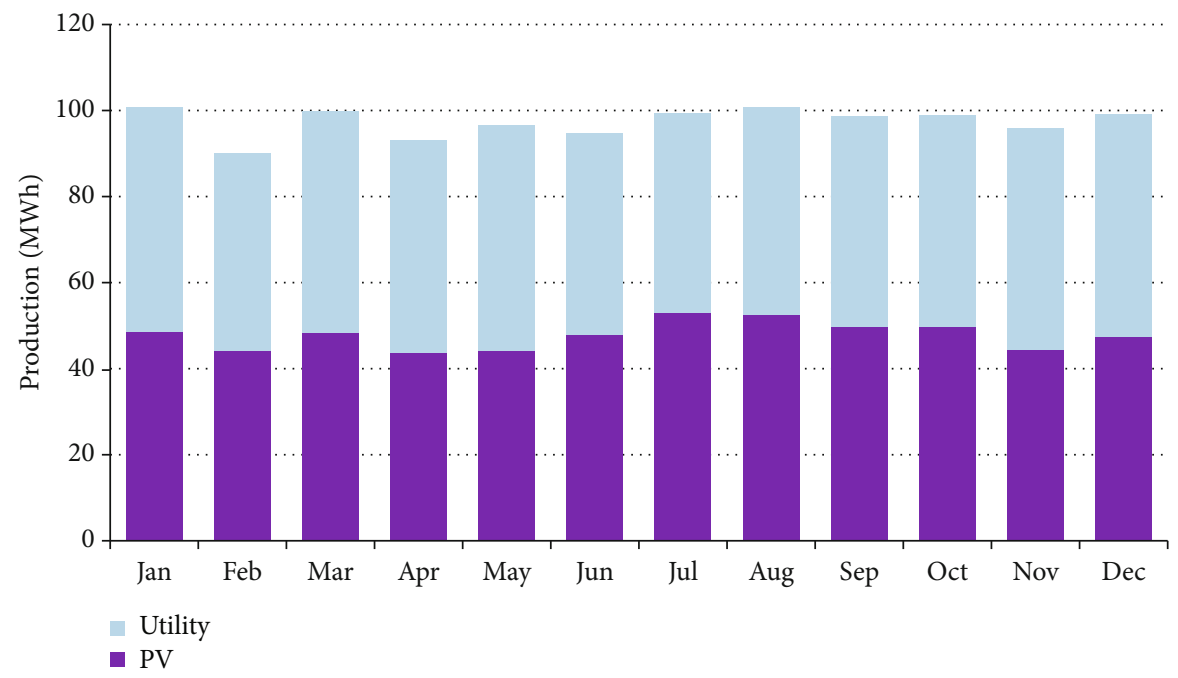

FIgURE 13: The electrical production for both utility and solar PV microgrid for the proposed technology in Uganda.

TABle 3: Project cost details (both grid and PV systems) for the whole project lifetime in Uganda.

\begin{tabular}{lcccccccccc}
\hline Year & 1 & 2 & 3 & 4 & 5 & 6 & 7 & 8 & 9 \\
\hline $\begin{array}{l}\text { PV } \\
\text { system }\end{array}$ & $(\$ 1,057.0)$ & $(\$ 1,057.0)$ & $(\$ 1,057.0)$ & $(\$ 1,057.0)$ & $(\$ 1,057.0)$ & $(\$ 1,057.0)$ & $(\$ 1,057.0)$ & $(\$ 1,057.0)$ & $(\$ 1,057.0)$ & $(\$ 1,057.0)$ \\
$\begin{array}{l}\text { Uganda } \\
\text { grid }\end{array}$ & $(\$ 92,435.0)$ & $(\$ 92,435.0)$ & $(\$ 92,435.0)$ & $(\$ 92,435.0)$ & $(\$ 92,435.0)$ & $(\$ 92,435.0)$ & $(\$ 92,435.0)$ & $(\$ 92,435.0)$ & $(\$ 92,435.0)$ & $(\$ 92,435.0)$ \\
Year & 11 & 12 & 13 & 14 & 15 & 16 & 17 & 18 & 19 \\
$\begin{array}{l}\text { PV } \\
\text { system }\end{array}$ & $(\$ 1,057.0)$ & $(\$ 1,057.0)$ & $(\$ 1,057.0)$ & $(\$ 1,057.0)$ & $(\$ 1,057.0)$ & $(\$ 1,057.0)$ & $(\$ 1,057.0)$ & $(\$ 1,057.0)$ & $(\$ 1,057.0)$ & $(\$ 1,057.0)$ \\
$\begin{array}{l}\text { Uganda } \\
\text { grid }\end{array}$ & $(\$ 92,435.0)$ & $(\$ 92,435.0)$ & $(\$ 92,435.0)$ & $(\$ 92,435.0)$ & $(\$ 92,435.0)$ & $(\$ 92,435.0)$ & $(\$ 92,435.0)$ & $(\$ 92,435.0)$ & $(\$ 92,435.0)$ & $(\$ 92,435.0)$ \\
$\begin{array}{l}\text { Year } \\
\text { PV }\end{array}$ & 21 & 22 & 23 & 24 & 25 & & & & & \\
system & $(\$ 1,057.0)$ & $(\$ 1,057.0)$ & $(\$ 1,057.0)$ & $(\$ 1,057.0)$ & $(\$ 1,057.0)$ & & & & & \\
$\begin{array}{l}\text { Uganda } \\
\text { gird }\end{array}$ & $(\$ 92,435.0)$ & $(\$ 92,435.0)$ & $(\$ 92,435.0)$ & $(\$ 92,435.0)$ & $(\$ 92,435.0)$ & & & & &
\end{tabular}

TABLE 4: Utility monthly summary-current system.

\begin{tabular}{|c|c|c|c|c|c|c|c|c|c|c|}
\hline Month & $\begin{array}{c}\text { Energy } \\
\text { purchased } \\
(\mathrm{kWh})\end{array}$ & $\begin{array}{l}\text { Energy sold } \\
\quad(\mathrm{kWh})\end{array}$ & $\begin{array}{c}\text { Net energy } \\
\text { purchased (kWh) }\end{array}$ & $\begin{array}{l}\text { Peak load } \\
\quad(\mathrm{kW})\end{array}$ & $\begin{array}{l}\text { Energy } \\
\text { charge }\end{array}$ & $\begin{array}{l}\text { Demand } \\
\text { charge }\end{array}$ & $\begin{array}{l}\text { Fixed } \\
\text { charge }\end{array}$ & $\begin{array}{l}\text { Minimum } \\
\text { charge }\end{array}$ & Taxes & Total \\
\hline January & $86,800.0$ & 0.0 & $86,800.0$ & 200.0 & $\$ 16,058.0$ & $\$ 0.0$ & $\$ 0.0$ & $\$ 0.0$ & $\$ 0.0$ & $\$ 16,058.0$ \\
\hline February & $78,400.0$ & 0.0 & $78,400.0$ & 200.0 & $\$ 14,504.0$ & $\$ 0.0$ & $\$ 0.0$ & $\$ 0.0$ & $\$ 0.0$ & $\$ 14,504.0$ \\
\hline March & $86,800.0$ & 0.0 & $86,800.0$ & 200.0 & $\$ 16,058.0$ & $\$ 0.0$ & $\$ 0.0$ & $\$ 0.0$ & $\$ 0.0$ & $\$ 16,058.0$ \\
\hline April & $84,000.0$ & 0.0 & $84,000.0$ & 200.0 & $\$ 15,540.0$ & $\$ 0.0$ & $\$ 0.0$ & $\$ 0.0$ & $\$ 0.0$ & $\$ 15,540.0$ \\
\hline May & $86,800.0$ & 0.0 & $86,800.0$ & 200.0 & $\$ 16,058.0$ & $\$ 0.0$ & $\$ 0.0$ & $\$ 0.0$ & $\$ 0.0$ & $\$ 16,058.0$ \\
\hline June & $84,000.0$ & 0.0 & $84,000.0$ & 200.0 & $\$ 15,540.0$ & $\$ 0.0$ & $\$ 0.0$ & $\$ 0.0$ & $\$ 0.0$ & $\$ 15,540.0$ \\
\hline July & $86,800.0$ & 0.0 & $86,800.0$ & 200.0 & $\$ 16,058.0$ & $\$ 0.0$ & $\$ 0.0$ & $\$ 0.0$ & $\$ 0.0$ & $\$ 16,058.0$ \\
\hline August & $86,800.0$ & 0.0 & $86,800.0$ & 200.0 & $\$ 16,058.0$ & $\$ 0.0$ & $\$ 0.0$ & $\$ 0.0$ & $\$ 0.0$ & $\$ 16,058.0$ \\
\hline September & $84,000.0$ & 0.0 & $84,000.0$ & 200.0 & $\$ 15,540.0$ & $\$ 0.0$ & $\$ 0.0$ & $\$ 0.0$ & $\$ 0.0$ & $\$ 15,540.0$ \\
\hline October & $86,800.0$ & 0.0 & $86,800.0$ & 200.0 & $\$ 16,058.0$ & $\$ 0.0$ & $\$ 0.0$ & $\$ 0.0$ & $\$ 0.0$ & $\$ 16,058.0$ \\
\hline November & $84,000.0$ & 0.0 & $84,000.0$ & 200.0 & $\$ 15,540.0$ & $\$ 0.0$ & $\$ 0.0$ & $\$ 0.0$ & $\$ 0.0$ & $\$ 15,540.0$ \\
\hline December & $86,800.0$ & 0.0 & $86,800.0$ & 200.0 & $\$ 16,058.0$ & $\$ 0.0$ & $\$ 0.0$ & $\$ 0.0$ & $\$ 0.0$ & $\$ 16,058.0$ \\
\hline Annual & $1,022,000.0$ & 0.0 & $1,022,000.0$ & 200.0 & $\$ 189,070.0$ & $\$ 0.0$ & $\$ 0.0$ & $\$ 0.0$ & $\$ 0.0$ & $\$ 189,070.0$ \\
\hline
\end{tabular}


TABLE 5: Utility monthly summary—proposed system.

\begin{tabular}{lcccccccccc}
\hline Month & $\begin{array}{c}\text { Energy } \\
\text { purchased } \\
(\mathrm{kWh})\end{array}$ & $\begin{array}{c}\text { Energy sold } \\
(\mathrm{kWh})\end{array}$ & $\begin{array}{c}\text { Net energy } \\
\text { purchased }(\mathrm{kWh})\end{array}$ & $\begin{array}{c}\text { Peak load } \\
(\mathrm{kW})\end{array}$ & $\begin{array}{c}\text { Energy } \\
\text { charge }\end{array}$ & $\begin{array}{c}\text { Demand } \\
\text { charge }\end{array}$ & $\begin{array}{c}\text { Fixed } \\
\text { charge }\end{array}$ & $\begin{array}{c}\text { Minimum } \\
\text { charge }\end{array}$ & $\begin{array}{c}\text { Taxes } \\
\text { Total }\end{array}$ \\
\hline January & $52,212.0$ & $14,065.0$ & $38,147.0 .0$ & 200.0 & $\$ 7,971.0$ & $\$ 0.0$ & $\$ 0.0$ & $\$ 0.0$ & $\$ 0.0$ & $\$ 7,971.0$ \\
February & $46,023.0$ & $11,782.0$ & $34,241.0$ & 200.0 .0 & $\$ 7,100.0$ & $\$ 0.0$ & $\$ 0.0$ & $\$ 0.0$ & $\$ 0.0$ & $\$ 7,100.0$ \\
March & $51,411.0$ & $12,956.0$ & $38,455.0$ & 200.0 & $\$ 7,956.0$ & $\$ 0.0$ & $\$ 0.0$ & $\$ 0.0$ & $\$ 0.0$ & $\$ 7,956.0$ \\
April & $49,352.0$ & $9,040.0$ & $40,312.0$ & 200.0 & $\$ 8,045.0$ & $\$ 0.0$ & $\$ 0.0$ & $\$ 0.0$ & $\$ 0.0$ & $\$ 8,045.0$ \\
May & $52,337.0$ & $9,631.0$ & $42,706.0$ & 200.0 & $\$ 8,527.0$ & $\$ 0.0$ & $\$ 0.0$ & $\$ 0.0$ & $\$ 0.0$ & $\$ 8,527.0$ \\
June & $46,764.0$ & $10,692.0$ & $36,071.0$ & 200.0 & $\$ 7,368.0$ & $\$ 0.0$ & $\$ 0.0$ & $\$ 0.0$ & $\$ 0.0$ & $\$ 7,368.0$ \\
July & $46,397.0$ & $12,516.0$ & $33,881.0$ & 200.0 & $\$ 7,082.0$ & $\$ 0.0$ & $\$ 0.0$ & $\$ 0.0$ & $\$ 0.0$ & $\$ 7,082.0$ \\
August & $48,330.0$ & $14,123.0$ & $34,207.0$ & 200.0 & $\$ 7,246.0$ & $\$ 0.0$ & $\$ 0.0$ & $\$ 0.0$ & $\$ 0.0$ & $\$ 7,246.0$ \\
September & $48,923.0$ & $14,567.0$ & $34,356.0$ & 200.0 & $\$ 7,303.0$ & $\$ 0.0$ & $\$ 0.0$ & $\$ 0.0$ & $\$ 0.0$ & $\$ 7,303.0$ \\
October & $49,226.0$ & $12,061.0$ & $37,165.0$ & 200.0 & $\$ 7,659.0$ & $\$ 0.0$ & $\$ 0.0$ & $\$ 0.0$ & $\$ 0.0$ & $\$ 7,659.0$ \\
November & $51,545.0$ & $12,024.0$ & $39,521.0$ & 200.0 & $\$ 8,093.0$ & $\$ 0.0$ & $\$ 0.0$ & $\$ 0.0$ & $\$ 0.0$ & $\$ 8,093.0$ \\
December & $51,780.0$ & $12,461.0$ & $39,319.0$ & 200.0 & $\$ 8,084.0$ & $\$ 0.0$ & $\$ 0.0$ & $\$ 0.0$ & $\$ 0.0$ & $\$ 8,084.0$ \\
Annual & $594,299.0$ & $145,918.0$ & $448,381.0$ & 200.0 & $\$ 92,435.0$ & $\$ 0.0$ & $\$ 0.0$ & $\$ 0.0$ & $\$ 0.0$ & $\$ 92,435.0$ \\
\hline
\end{tabular}

off-grid communities, roughly 63 minigrids were operating in Kenya by the end of 2017 [25]. Twenty-nine are operated by either the national utility Kenya Power (KP) or the Rural Electrification and Renewable Energy Corporation (REREC), and 23 of them are run by private developers and 11 by communal organizations.

Kenya is leading the East African community nations in solar PV deployment with a total of $94.54 \mathrm{MW}$ already installed [26]. Although the number of minigrids is less than that of Tanzania (as can be shown in Figure 14), the country has installed several megawatt-scale minigrids in several institutions, private agricultural farms, and for local populations among others. The solar PV minigrid technology is well understood in the country, and there is also motivation from the substandard service offered by the national utility where power cuts are very common and the billing exorbitant [25]. Most private institutions have also been encouraged to get a minigrid as there is provision for a power purchase agreement (PPA) with the national utility at a somewhat reasonable price of USD $0.12[27,28]$ besides avoiding the power cuts and overpriced bills. Private minigrids on agricultural estates are a common phenomenon as they do not require a permit or license to generate electricity equal to or less than 1.0 MW for their use [25].

According to Kenya national electrification strategy, the country has an ambitious plan to achieve $100.0 \%$ electrification by 2022 [29]. Currently, it also has the leading electricity access rate in East Africa at 84.5\% [22] both from on-grid and off-grid solutions and is home to the largest (50.0 MW) gridconnected solar PV minigrid in East and Central Africa, located in Garissa county as shown in Figure 15. The country experienced extensive growth in the year 2018 with an additional 55.0 MW being installed, before that, the growth was rather gentle. In 2019, only $2.0 \mathrm{MW}$ was installed, signaling a return to a slow rise as experienced before.

Going forward, additional minigrids are under development or planned for construction, typically funded by donors but cofinanced and implemented by the private sector. These

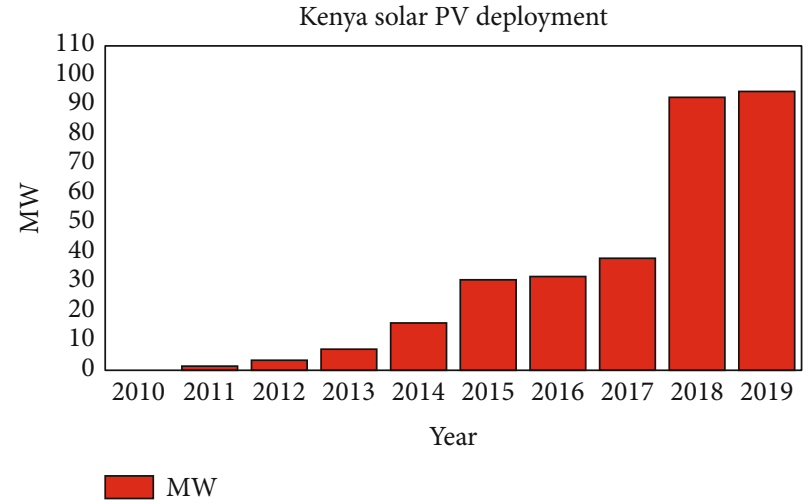

FIgURe 14: Solar PV trends in Kenya by IRENA.

include the 120 minigrids under an off-grid solar access project to be implemented under a public-private partnership (PPP) model jointly by REREC and Kenya Power [30]. Each specific minigrid will combine solar PV, storage batteries, and thermal units running on fossil fuels. REREC is developing another 53 sites with financing from donors and the exchequer, all while the private sector is currently at various development stages on at least 133 minigrids [31]. Table 6 describes the institutions involved in Kenya's energy sector.

Presently, projects in Kenya are regulated by the Energy and Petroleum Regulatory Authority (EPRA) based on their capacity, with minigrids of up to $3.0 \mathrm{MW}$ a capacity requiring a permit, tariff approval, technical standards, and general oversight. Minigrids exceeding $3 \mathrm{MW}$ require a license while those under 1.0 MW generating for private use require neither a permit nor a license [37]. Figure 16 indicates the monthly solar GHI for Kenya. It rises from $5.614 \mathrm{kWh} / \mathrm{m}^{2} /$ day in January to $5.977 \mathrm{kWh} / \mathrm{m}^{2} /$ day in February and decreases irregularly to $4.231 \mathrm{kWh} / \mathrm{m}^{2} /$ day in May. The GHI rose slightly to 4.241 in June and declines slightly to the lowest point in July at $4.038 \mathrm{kWh} / \mathrm{m}^{2} /$ day. It rises again slightly to $4.191 \mathrm{kWh} / \mathrm{m}^{2} /$ day in August and then $5.179 \mathrm{kWh} / \mathrm{m}^{2} /$ day 


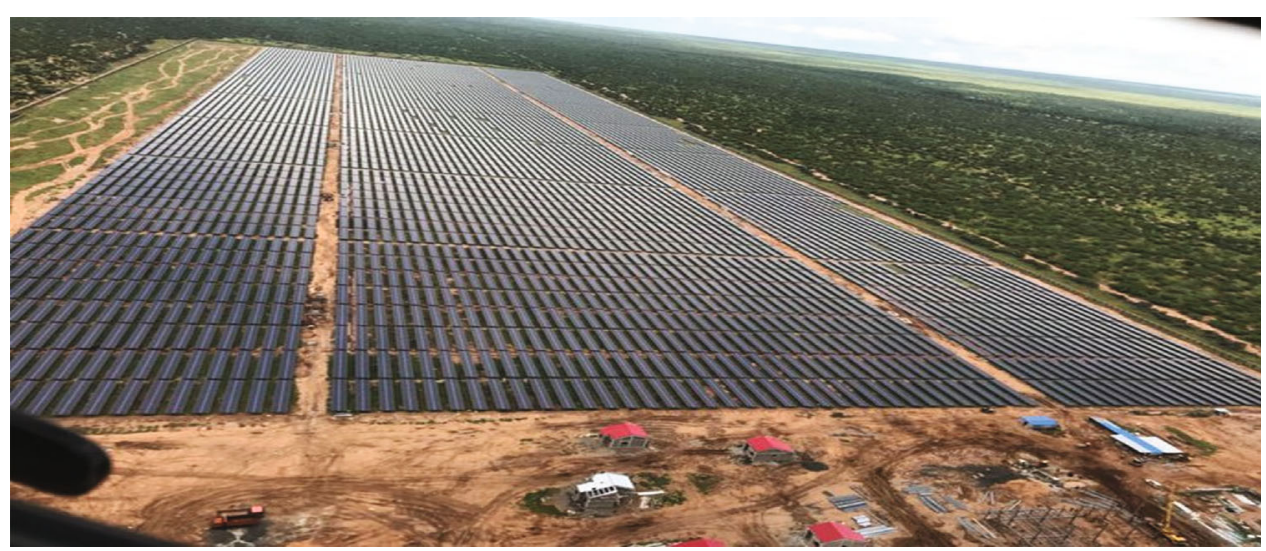

Figure 15: Mbalambala Garissa solar PV minigrid with 200,200 solar panels and 50.0 MW capacity (photo on-site at Mbalambala Garissa).

TABLE 6: Description of institutions involved in Kenya's energy sector.

\begin{tabular}{l} 
Institution \\
\hline Ministry of Energy \\
Energy and Petroleum Regulatory \\
Authority (EPRA) \\
Kenya Electricity Generating Company \\
(KenGen) \\
Kenya Power \\
Rural Electrification and Renewable \\
Energy Corporation (REREC) \\
Energy Tribunal \\
IPP's (Independent Power Producers)
\end{tabular}

Mandate

Formulates and enforces regulations on grid codes, tariffs, and other relevant tools necessary.

Oversees electricity generation, $70.0 \%$ owned by the government, $30.0 \%$ by private investors agreed feed-in tariff.

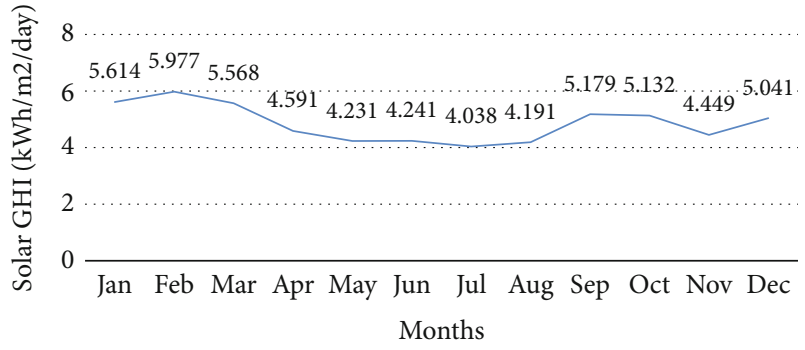

FIGURE 16: Monthly solar Global Horizontal Irradiation (GHI $\mathrm{kWh} / \mathrm{m}^{2} /$ day) for Kenya.

peak in September. It decreases slightly to $5.132 \mathrm{kWh} / \mathrm{m}^{2} /$ day in October and falls to $4.449 \mathrm{kWh} / \mathrm{m}^{2} /$ day in November, before rising to $5.041 \mathrm{kWh} / \mathrm{m}^{2} /$ day in December, respectively.

Figure 17 depicts the clearness index (CI) for Kenya. The CI rises from 0.55 in January to 0.571 in February and falls to 0.529 in March. It gradually declines to 0.453 in April, 0.444 in May, and 0.463 in June. It further declines to 0.434 in July and 0.426 in August. It rises to 0.502 in September, declines to 0.492 in October and 0.435 in November, and rose to 0.501 in December.

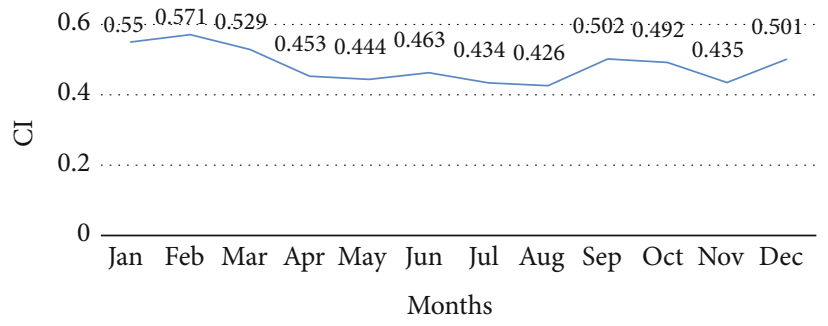

Figure 17: Monthly clearness index (CI) for Kenya.

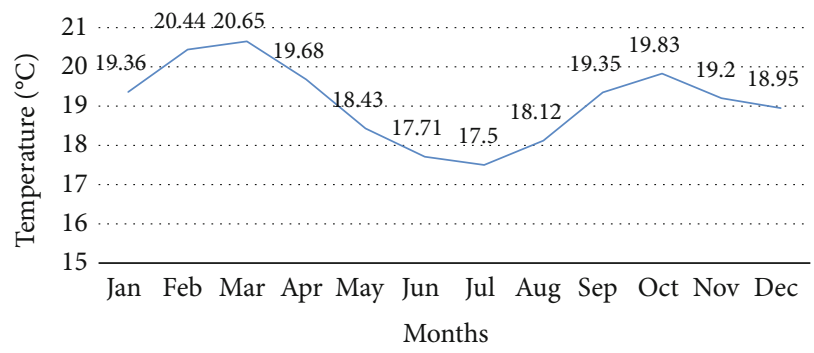

Figure 18: Monthly temperature variation $\left({ }^{\circ} \mathrm{C}\right)$ for Kenya. 


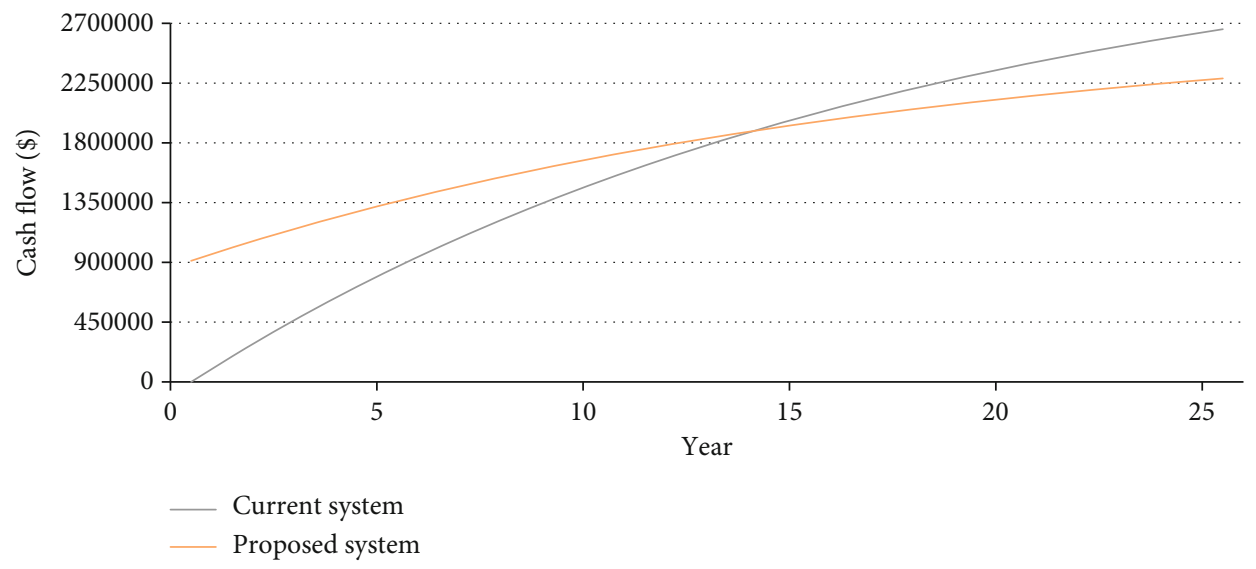

FIGURE 19: Cumulative cash flows over project lifetime for the current and proposed systems for Kenya.

Figure 18 shows the monthly temperature variation for Kenya. The temperature rose from $19.36^{\circ} \mathrm{C}$ in January to $20.44^{\circ} \mathrm{C}$ in February and $20.65^{\circ} \mathrm{C}$ (peak) in March. The temperature declines to the lowest $17.50^{\circ} \mathrm{C}$ in July, rose to $19.83^{\circ} \mathrm{C}$ in October, and declined to $18.93^{\circ} \mathrm{C}$ in December. Figure 19 indicates the cumulative cash flow over the project life for both the current and proposed power systems for Kenya. The current and proposed power systems curves were graphed. At inception, the current system cash flow was around US\$-217,741.94 while the proposed power system cash flow was US\$900,000.00. Both the proposed and current power systems cash flows were US\$1,872,580.65 and US $\$ 1,872,580.65$ respectively, and at the same 14.17 years. At the end of their economic lives, both the current and proposed power systems cash flows were around US\$2,656,451.16 and US $\$ 2,250.00$, respectively. Assuming a triangle for the current power system and a trapezium for the proposed power system, both the current and proposed power systems cash flows will be about US\$33,205,645.20 and US\$39,375,000.00, respectively. Therefore, US\$6,139,354.80 is the cash flow advantage of the proposed power system over the current power system.

Figure 20 reflects the categorized annual savings for the proposed power system in Kenya. The annual energy value was US\$100,246.00, and US\$-1,057.00 was the operations and maintenance costs, while US\$99,190.00 was the annual energy savings using the proposed power system for electrification.

Figure 21 indicates the monthly utility bills for both the current and proposed power systems in Kenya. The January bills for both the current and proposed power systems were US $\$ 17,437.50$ and US $\$ 7,875.00$, respectively. The February bills for both the current and proposed power systems were US $\$ 15,750.00$ and US $\$ 6,562.50$, respectively. The March bills for both the current and proposed power systems were US\$16,901.37 and US\$7,875.00, respectively. The April bills for both the current and proposed power systems were US $\$ 16,875.00$ and US $\$ 8,812.50$, respectively. The May bills for both the current and proposed power systems were US $\$ 16,901.37$ and US $\$ 9,843.75$, respectively. The June bills for both the current and proposed power systems were US $\$ 16,875.00$ and US\$9,375.00, respectively. The July bills for both the current and proposed power systems were
17,437.50 and US\$10,125.00, respectively. The August bills for both the current and proposed power systems were US\$16,901.37 and US\$9,937.50, respectively. The September bills for both the current and proposed power systems were US $\$ 16,875.00$ and US\$9,937.50, respectively. The October bills for both the current and proposed power systems were US\$17,437.50 and US\$8,437.50, respectively. The November bills for both the current and proposed power systems were US\$16,875.00 and US\$9,375.00, respectively. The December bills for both the current and proposed power systems were US $\$ 17,437.50$ and US $\$ 8,812.50$, respectively.

Table 7 depicts annual utility bills and savings by category in Kenya. The current consumption charge was US\$205,422.00 while the proposed power system consumption charge was US\$105,176.00 and US\$100,246.00 was the annual energy savings.

Figure 22 indicates the electrical production capacities for both the current and proposed power systems in Kenya. The January electricity production capacities for both the grid and solar PV microgrid were 104.07 MWh and 55.22 MWh, respectively. The February production capacities for both the grid and solar PV microgrid were $95.56 \mathrm{MWh}$ and 53.10 MWh, respectively. The March production capacities for both the grid and solar PV microgrid were 104.07 MWh and 55.22 MWh, respectively. The April production capacities for both the grid and solar PV microgrid were 93.45 MWh and 44.60 MWh, respectively. The May production capacities for both the grid and solar PV microgrid were 95.56 MWh and 42.48 MWh, respectively. The June production capacities for both the grid and solar PV microgrid were 91.33 MWh and 40.35 MWh, respectively. The July production capacities for both the grid and solar PV microgrid were 95.56 MWh and 40.35 MWh, respectively. The August production capacities for both the grid and solar PV microgrid were 95.56 MWh and 41.42 MWh, respectively. The September production capacities for both the grid and solar PV microgrid were 98.76 MWh and 49.91 MWh, respectively. The October production capacities for both the grid and solar PV microgrid were $99.18 \mathrm{MWh}$ and $50.97 \mathrm{MWh}$, respectively. The November production capacities for both the grid and solar PV microgrid were 95.58 MWh and 42.48 MWh, 


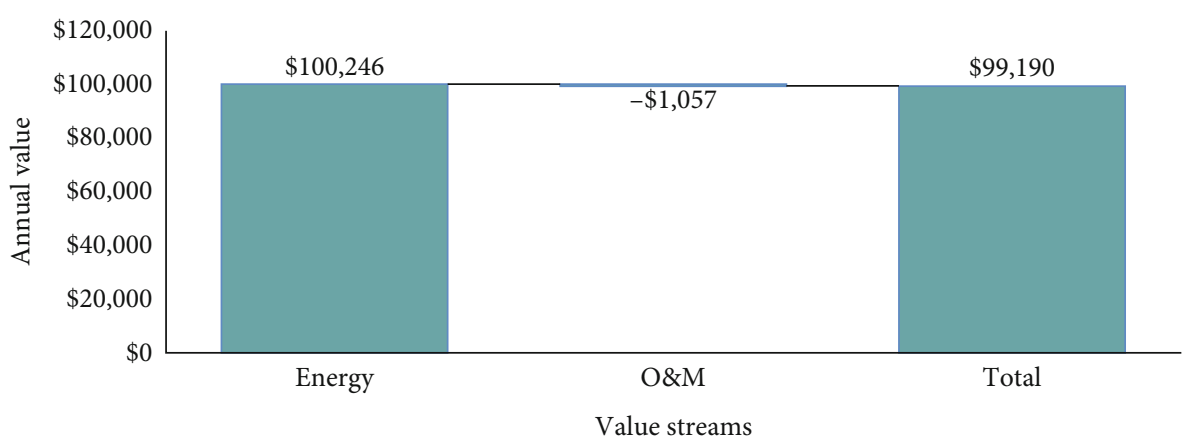

FIGURE 20: Categorized annual savings for a proposed system for Kenya.

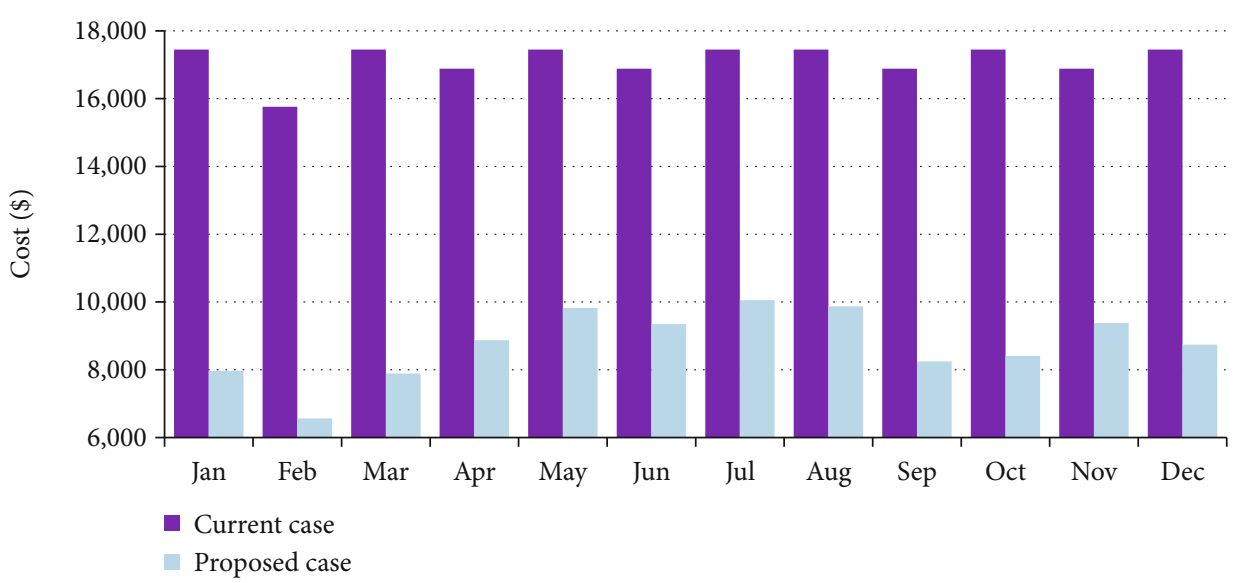

FIGURE 21: Monthly utility bills for the current and proposed systems for Kenya.

TABLE 7: Annual utility bills and savings by category (Kenya).

\begin{tabular}{lcc}
\hline & Consumption charge & Total \\
\hline Base case & $\$ 205,422.0$ & $\$ 205,422.0$ \\
Proposed case & $\$ 105,176.0$ & $\$ 105,176.0$ \\
Annual savings & $\$ 100,246.0$ & $\$ 100,246.0$ \\
\hline
\end{tabular}

Note: the base case is considered as the current system (grid connection) and the proposed case is the grid-connected solar PV microgrid with storage.

respectively. The December production capacities for both the grid and solar PV microgrid were 100.0 MWh and 48.85 MWh, respectively.

The solar PV system has a nominal capacity of $400.0 \mathrm{~kW}$, and its annual production is $565217.0 \mathrm{kWh} /$ year, and a specific yield of $1413.0 \mathrm{kWh} / \mathrm{kW}$.

Table 8 depicts the project cost details for grid and solar PV systems in Kenya. The economic life span for each power system was 25 years, and the grid project cost was US $\$ 105,176.00$ per year while US $\$ 1,057.00$ was the yearly cost for the solar PV system.

Table 9 indicates the monthly utility summary for the current power system in Kenya. The energy purchase (kWh) for January, March, May, July, August, October, and December was each $86,800.0 \mathrm{kWh}$ while $78,400.0 \mathrm{kWh}$ was for February, the months of April, June, September, and November was each $84,000.0 \mathrm{kWh}$, respectively. The annual energy purchase was $1,022,000.0 \mathrm{kWh}$. The peak load was 200.0 kWp, and the total energy charge was US\$205,422.00.

Table 10 depicts the monthly utility summary for the proposed power system in Kenya. The energy purchase, energy sold, and net energy purchase for each month of the year were variable. The annual energy purchased and sold were $603,622 \mathrm{kWh}$ and $146,889.0 \mathrm{kWh}$, respectively. The peak load was $200.0 \mathrm{kWp}$ but the energy charge was as variable as each month of the year. The demand charge, minimum charge, fixed charge, and taxes were each zero, respectively. Also, the total annual energy charge was US\$105,176.0

4.1.3. United Republic of Tanzania. Tanzania has between 2,800.0 and 3,500.0 sunshine hours per year with a maximum global horizontal radiation of $7.0 \mathrm{kWh}$ per $\mathrm{m}^{2}$ per day [14]. Currently, $25.56 \mathrm{MW}$ of solar PV energy has been installed in Tanzania [26]. Tanzania has 209 identified minigrids installed with a collective capacity of $231.7 \mathrm{MW}$ [9]. These projects are roughly 15.0 percent of the country's entire capacity of 1,461.0 MW. Nearly one-third of these projects are either solar-hybrid or solar minigrids. According to the World Resources Institute (WRI) and Tanzania Traditional Energy Development Organization (TATEDO), there were 109 minigrids in Tanzania by the end of $2017,46.0 \%$ of the minigrids are hydro, $18.0 \%$ are fossil fuels, $24.0 \%$ are biomass, and $12.0 \%$ are solar minigrids and no wind minigrids 


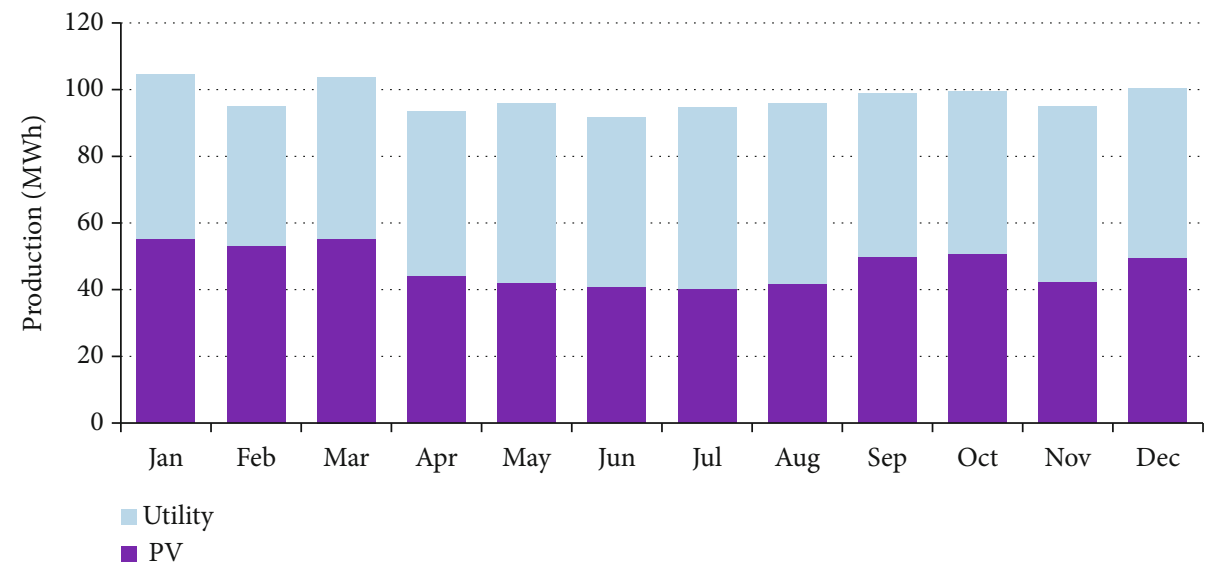

FIgURE 22: The electrical production for both utility and the solar PV microgrid for the proposed technology in Kenya.

in Tanzania [38]. Sixteen of these plants were tied to the central grid with the other 93 operating in isolation. While a majority of the capacity is distributed to the customers, some are sold to Tanzania Electric Supply Company (TANESCO) for distribution through the central grid. Figure 23 shows the minigrids location and numbers in Tanzania [38]. Figure 23 is a map indicating the locations of minigrids in Tanzania. The minigrids comprise biomass, fossil fuels, hybrid, solar, and hydropower.

The electricity access rate in Tanzania was $36 \%$ by the end of 2019 [22], and the country is home to the largest population without electricity at slightly above 35 million compared to the other East African nations [5, 22]. This makes Tanzania the largest market in East Africa for electrification technologies. Minigrid technologies in Tanzania are a fairly mature concept, and the growth of solar PV deployment in Tanzania has been steady [39] as it can be shown by Figure 24. There was a big leap in installations in the years 2014 and 2016 when $7 \mathrm{MW}$ and $6 \mathrm{MW}$ of solar power were injected into the market respectively (Figure 9). There was no increase experienced in 2019 an indication of slowing growth, and the total solar PV electricity capacity stood at $25.56 \mathrm{MW}$ by the end of 2019 [26]. Figure 24 reflects the solar PV trends in Tanzania between 2010 and 2019 (inclusive) in MW. The solar PV deployment was around $0.17 \mathrm{MW}$ in 2010, $0.52 \mathrm{MW}$ in 2011, $1.03 \mathrm{MW}$ in 2012, 3.62 MW in $2013,11.12 \mathrm{MW}$ in $2014,12.93 \mathrm{MW}$ in $2015,18.36 \mathrm{MW}$ in 2016, 21.88 MW in 2017, 25.34 MW in 2018, and $25.50 \mathrm{MW}$ in 2019.

A government initiative by the name of small power producers (SPP) framework seems to have a positive impact on minigrid installations [40]. The SPP policy structure terms a small power producer (SPP) as any minigrid less than 10.0 MW a capacity. The policy allows the direct sale of electricity from minigrids to consumers. It provides that if the national grid extends to minigrid territory then power can be sold to TANESCO, the national utility. Nine registered SPPs were serving offgrid populations as of the year 2018. The policy has had a significant impact by nearly doubling both the capacity and number of minigrids in Tanzania since 2008 when the SPP framework was introduced. A total of $67.0 \mathrm{MW}$ of new capacity were installed through fifty-two additional minigrids commissioned between 2008 and 2016 [2, 11]. The SPP structure requires all minigrids to have a license and tariff approval; however, any mini-grid with a capacity above $100.0 \mathrm{~kW}$ does not enjoy tariff structure flexibility and therefore operates under a fixed tariff [11]. Further support from the government includes removing valueadded tax (VAT) and other importation duties on most solar components. Additionally, the government through the Rural Energy Agency (REA) which manages the Rural Energy Fund (REF) offers the following incentives to rural energy projects; (a) grants of up to USD 100,000.0 for feasibility studies or 80 percent of the cost of study, (b) grants for each home connection to the national utility grid or minigrids of up to 500.0 USD, or a maximum of 80.0 percent of the project's distribution and transmission costs, and (c) infrastructure credits up to 85.0 percent for power generation investments of less than $3.0 \mathrm{MW}(70.0$ percent for projects greater than $3.0 \mathrm{MW}$ ).

Onwards, Tanzania is planning to develop an extra 60 solar minigrids in rural areas following a business deal between a local developer and several international funding agencies as of July 2019 [41]. Innovative project financing remains key for the construction of the minigrids intended to connect a majority of the 36 million people still inaccessible to electricity in Tanzania. Currently, there are several megawatt-scale solar PV developments being installed or planned. Once built, the projects will improve the service offered by the local grid, which has habitual power cuts fluctuations. Table 11 describes the institutions involved in the Tanzanian energy sector.

Figure 25 indicates the monthly solar GHI $\left(\mathrm{kWh} / \mathrm{m}^{2} /\right.$ day) for Tanzania. The GHI rose from $5.614 \mathrm{kWh} / \mathrm{m}^{2} /$ day in January to $5.977 \mathrm{kWh} / \mathrm{m}^{2} /$ day in February $\mathrm{kWh} / \mathrm{m}^{2} /$ day (peak) and decreases to $5.568 \mathrm{kWh} / \mathrm{m}^{2} /$ day in March to $4.591 \mathrm{kWh} / \mathrm{m}^{2} /$ day in April to $4.231 \mathrm{kWh} / \mathrm{m}^{2} /$ day in May. The GHI rose slightly to $4.241 \mathrm{kWh} / \mathrm{m}^{2} /$ day in June, decreases to $4.038 \mathrm{kWh} / \mathrm{m}^{2} /$ day in July, and rose to $4.191 \mathrm{kWh} / \mathrm{m}^{2} /$ day in August. From $5.197 \mathrm{kWh} / \mathrm{m}^{2} /$ day in September, it decreases slightly to 


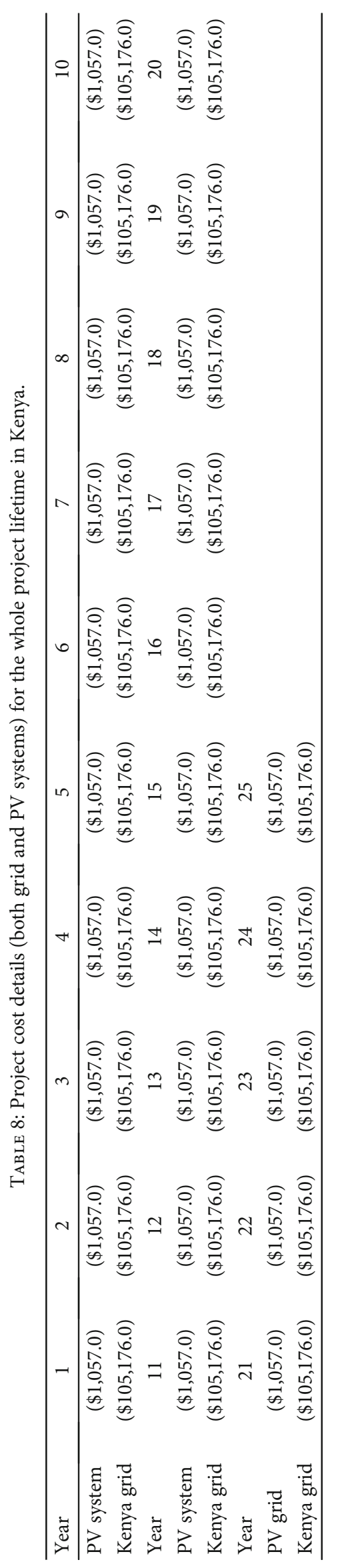


TABLE 9: Utility monthly summary—current system (Kenya).

\begin{tabular}{|c|c|c|c|c|c|c|c|c|c|c|}
\hline Month & $\begin{array}{c}\text { Energy } \\
\text { purchased } \\
(\mathrm{kWh})\end{array}$ & $\begin{array}{l}\text { Energy sold } \\
\quad(\mathrm{kWh})\end{array}$ & $\begin{array}{c}\text { Net energy } \\
\text { purchased }(\mathrm{kWh})\end{array}$ & $\begin{array}{l}\text { Peak load } \\
(\mathrm{kW})\end{array}$ & $\begin{array}{l}\text { Energy } \\
\text { charge }\end{array}$ & $\begin{array}{l}\text { Demand } \\
\text { charge }\end{array}$ & $\begin{array}{l}\text { Fixed } \\
\text { charge }\end{array}$ & $\begin{array}{l}\text { Minimum } \\
\text { charge }\end{array}$ & Taxes & Total \\
\hline January & $86,800.0$ & 0.0 & $86,800.0$ & 200.0 & $\$ 17,447.0$ & $\$ 0.0$ & $\$ 0.0$ & $\$ 0.0$ & $\$ 0.0$ & $\$ 17,447.0$ \\
\hline February & $78,400.0$ & 0.0 & $78,400.0$ & 200.0 & $\$ 15,758.0$ & $\$ 0.0$ & $\$ 0.0$ & $\$ 0.0$ & $\$ 0.0$ & $\$ 15,758.0$ \\
\hline March & $86,800.0$ & 0.0 & $86,800.0$ & 200.0 & $\$ 17,447.0$ & $\$ 0.0$ & $\$ 0.0$ & $\$ 0.0$ & $\$ 0.0$ & $\$ 17,447.0$ \\
\hline April & $84,000.0$ & 0.0 & $84,000.0$ & 200.0 & $\$ 16,884.0$ & $\$ 0.0$ & $\$ 0.0$ & $\$ 0.0$ & $\$ 0.0$ & $\$ 16,884.0$ \\
\hline May & $86,800.0$ & 0.0 & $86,800.0$ & 200.0 & $\$ 17,447.0$ & $\$ 0.0$ & $\$ 0.0$ & $\$ 0.0$ & $\$ 0.0$ & $\$ 17,447.0$ \\
\hline June & $84,000.0$ & 0.0 & $84,000.0$ & 200.0 & $\$ 16,884.0$ & $\$ 0.0$ & $\$ 0.0$ & $\$ 0.0$ & $\$ 0.0$ & $\$ 16,884.0$ \\
\hline July & $86,800.0$ & 0.0 & $86,800.0$ & 200.0 & $\$ 17,447.0$ & $\$ 0.0$ & $\$ 0.0$ & $\$ 0.0$ & $\$ 0.0$ & $\$ 17,447.0$ \\
\hline August & $86,800.0$ & 0.0 & $86,800.0$ & 200.0 & $\$ 17,447.0$ & $\$ 0.0$ & $\$ 0.0$ & $\$ 0.0$ & $\$ 0.0$ & $\$ 17,447.0$ \\
\hline September & $84,000.0$ & 0.0 & $84,000.0$ & 200.0 & $\$ 16,884.0$ & $\$ 0.0$ & $\$ 0.0$ & $\$ 0.0$ & $\$ 0.0$ & $\$ 16,884.0$ \\
\hline October & $86,800.0$ & 0.0 & $86,800.0$ & 200.0 & $\$ 17,447.0$ & $\$ 0.0$ & $\$ 0.0$ & $\$ 0.0$ & $\$ 0.0$ & $\$ 17,447.0$ \\
\hline November & $84,000.0$ & 0.0 & $84,000.0$ & 200.0 & $\$ 16,884.0$ & $\$ 0.0$ & $\$ 0.0$ & $\$ 0.0$ & $\$ 0.0$ & $\$ 16,884.0$ \\
\hline December & $86,800.0$ & 0.0 & $86,800.0$ & 200.0 & $\$ 17,447.0$ & $\$ 0.0$ & $\$ 0.0$ & $\$ 0.0$ & $\$ 0.0$ & $\$ 17,447.0$ \\
\hline Annual & $1,022,000.0$ & 0.0 & $1,022,000.0$ & 200.0 & $\$ 205,422.0$ & $\$ 0.0$ & $\$ 0.0$ & $\$ 0.0$ & $\$ 0.0$ & $\$ 205,422.0$ \\
\hline
\end{tabular}

TABLE 10: Utility monthly summary-proposed system (Kenya).

\begin{tabular}{|c|c|c|c|c|c|c|c|c|c|c|}
\hline Month & $\begin{array}{c}\text { Energy } \\
\text { purchased } \\
(\mathrm{kWh})\end{array}$ & $\begin{array}{l}\text { Energy sold } \\
\text { (kWh) }\end{array}$ & $\begin{array}{c}\text { Net energy } \\
\text { purchased (kWh) }\end{array}$ & $\begin{array}{l}\text { Peak load } \\
\quad(\mathrm{kW})\end{array}$ & $\begin{array}{l}\text { Energy } \\
\text { charge }\end{array}$ & $\begin{array}{l}\text { Demand } \\
\text { charge }\end{array}$ & $\begin{array}{l}\text { Fixed } \\
\text { charge }\end{array}$ & $\begin{array}{l}\text { Minimum } \\
\text { charge }\end{array}$ & Taxes & Total \\
\hline January & $49,312.0$ & $17,658.0$ & $31,653.0$ & 200.0 & $\$ 7,969.0$ & $\$ 0.0$ & $\$ 0.0$ & $\$ 0.0$ & $\$ 0.0$ & $\$ 7,969.0$ \\
\hline February & $41,806.0$ & $16,698.0$ & $25,108.0$ & 200.0 & $\$ 6,566.0$ & $\$ 0.0$ & $\$ 0.0$ & $\$ 0.0$ & $\$ 0.0$ & $\$ 6,566.0$ \\
\hline March & $48,471.0$ & $16,855.0$ & $31,616.0$ & 200.0 & $\$ 7,889.0$ & $\$ 0.0$ & $\$ 0.0$ & $\$ 0.0$ & $\$ 0.0$ & $\$ 7,889.0$ \\
\hline April & $49,341.0$ & $9,481.0$ & $39,860.0$ & 200.0 & $\$ 8,875.0$ & $\$ 0.0$ & $\$ 0.0$ & $\$ 0.0$ & $\$ 0.0$ & $\$ 8,875.0$ \\
\hline May & $53,773.0$ & $8,967.0$ & $44,806.0$ & 200.0 & $\$ 9,822.0$ & $\$ 0.0$ & $\$ 0.0$ & $\$ 0.0$ & $\$ 0.0$ & $\$ 9,822.0$ \\
\hline June & $50,797.0$ & $7,832.0$ & $42,965.0$ & 200.0 & $\$ 9,349.0$ & $\$ 0.0$ & $\$ 0.0$ & $\$ 0.0$ & $\$ 0.0$ & $\$ 9,349.0$ \\
\hline July & $54,367.0$ & $7,952.0$ & $46,415.0$ & 200.0 & $\$ 10,053.0$ & $\$ 0.0$ & $\$ 0.0$ & $\$ 0.0$ & $\$ 0.0$ & $\$ 10,053.0$ \\
\hline August & $54,031.0$ & $9,011.0$ & $45,020.0$ & 200.0 & $\$ 9,869.0$ & $\$ 0.0$ & $\$ 0.0$ & $\$ 0.0$ & $\$ 0.0$ & $\$ 9,869.0$ \\
\hline September & $49,175.0$ & $14,876.0$ & $34,299.0$ & 200.0 & $\$ 8,248.0$ & $\$ 0.0$ & $\$ 0.0$ & $\$ 0.0$ & $\$ 0.0$ & $\$ 8,248.0$ \\
\hline October & $48,819.0$ & $12,750.0$ & $36,068.0$ & 200.0 & $\$ 8,410.0$ & $\$ 0.0$ & $\$ 0.0$ & $\$ 0.0$ & $\$ 0.0$ & $\$ 8,410.0$ \\
\hline November & $52,791.0$ & $11,173.0$ & $41,618.0$ & 200.0 & $\$ 9,382.0$ & $\$ 0.0$ & $\$ 0.0$ & $\$ 0.0$ & $\$ 0.0$ & $\$ 9,382.0$ \\
\hline December & $50,940.0$ & $13,586.0$ & $37,354.0$ & 200.0 & $\$ 8,744.0$ & $\$ 0.0$ & $\$ 0.0$ & $\$ 0.0$ & $\$ 0.0$ & $\$ 8,744.0$ \\
\hline Annual & $603,622.0$ & $146,839.0$ & $456,783.0$ & 200.0 & $\$ 105,176.0$ & $\$ 0.0$ & $\$ 0.0$ & $\$ 0.0$ & $\$ 0.0$ & $\$ 105,176.0$ \\
\hline
\end{tabular}

$5.132 \mathrm{kWh} / \mathrm{m}^{2} /$ day in October, to $4.459 \mathrm{kWh} / \mathrm{m}^{2} /$ day in November, and rises to $5.041 \mathrm{kWh} / \mathrm{m}^{2} /$ day.

Figure 26 shows the monthly clearness index (CI) for Tanzania. The CI increased from 0.550 in January to 0.571 (peak) in February and declines to 0.529 in March, 0.453 in April, 0.444 in May, rose slightly to 0.463 in June, and declines to 0.434 in July. The lowest 0.426 CI occurred in August, it rose to 0.502 in September and decreases to 0.492 in October, and 0.435 in November, and finally rose to 0.501 in December.

Figure 27 depicts the monthly temperature variation for Tanzania. The temperature rose from $19.36^{\circ} \mathrm{C}$ in January to $20.44^{\circ} \mathrm{C}$ in February and peaked at $20.65^{\circ} \mathrm{C}$ in March. It declines to $19.68^{\circ} \mathrm{C}$ in April, $18.43^{\circ} \mathrm{C}$ in May, $17.71^{\circ} \mathrm{C}$ in June, and $17.5^{\circ} \mathrm{C}$ in July. The temperature gently rose to $18.12^{\circ} \mathrm{C}$ in August, $19.35^{\circ} \mathrm{C}$ in September, and $19.83^{\circ} \mathrm{C}$ in October. The temperature decreases to $19.2^{\circ} \mathrm{C}$ in November and $18.95^{\circ} \mathrm{C}$ in December, respectively.

Figure 28 indicates the cumulative cash flows over the lifetime of the proposed power system in Tanzania. The cumulative cash flows at inception were zero while it was US\$1,500,000.00 at the 25-year economic life span. The cash flow at 2.83 years was US $\$ 300,000.00$, US\$600,000.00 at 6.5 years, US $\$ 900,000.00$ at 10.83 years, US $\$ 1,200,000.00$ by 16.5 years, and US $\$ 1,500,000.00$ by the 25 th year, respectively.

Table 12 shows the projected grid cost details for the 25year economic lifespan for Tanzania. The cost detail was US\$117,530.00 for each of the 25 years, respectively.

4.1.4. Republic of Burundi. Burundi's sunshine hours range between 1680 and 2045 per year with global horizontal 


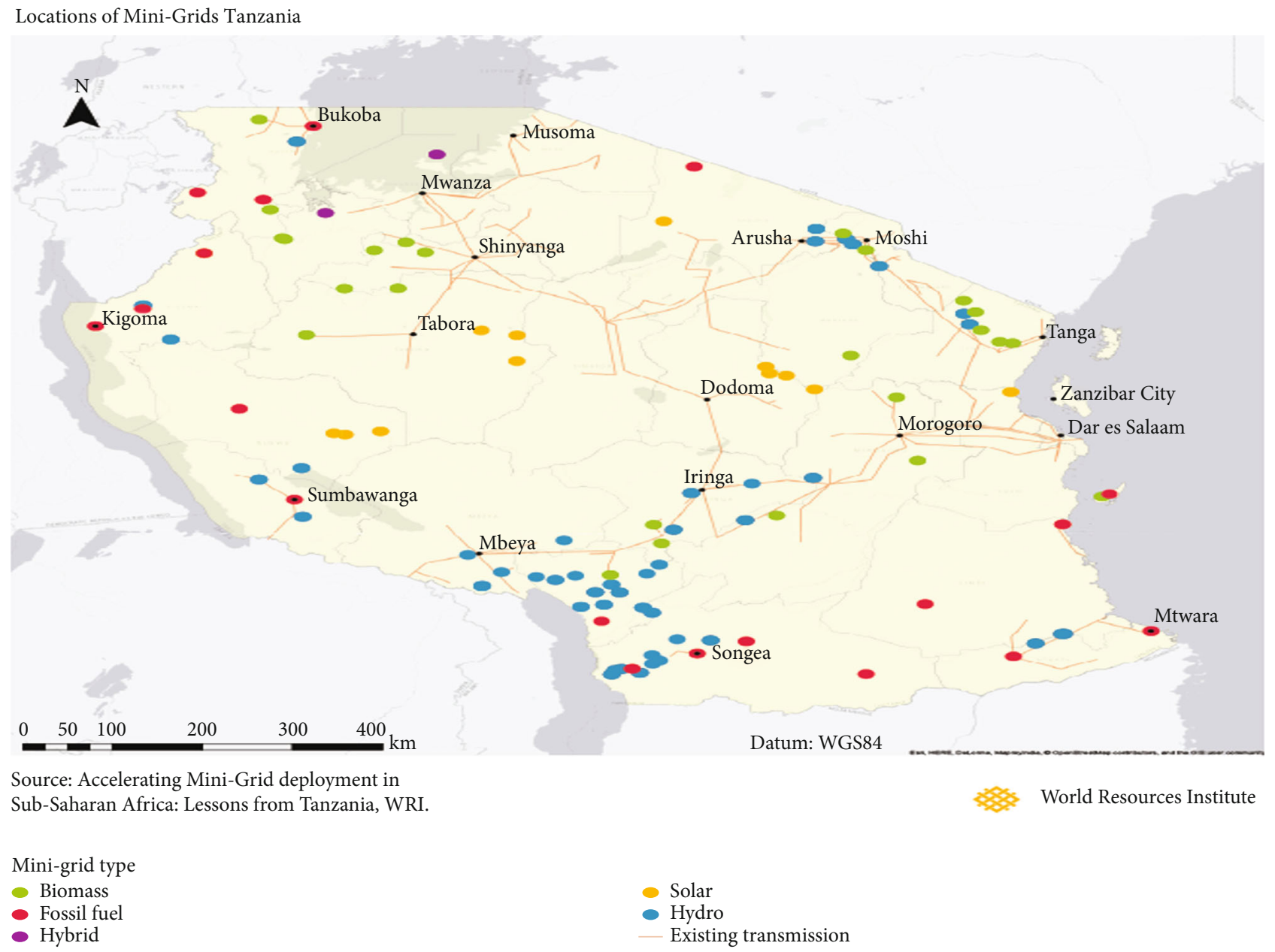

Figure 23: Minigrid locations and numbers in Tanzania.

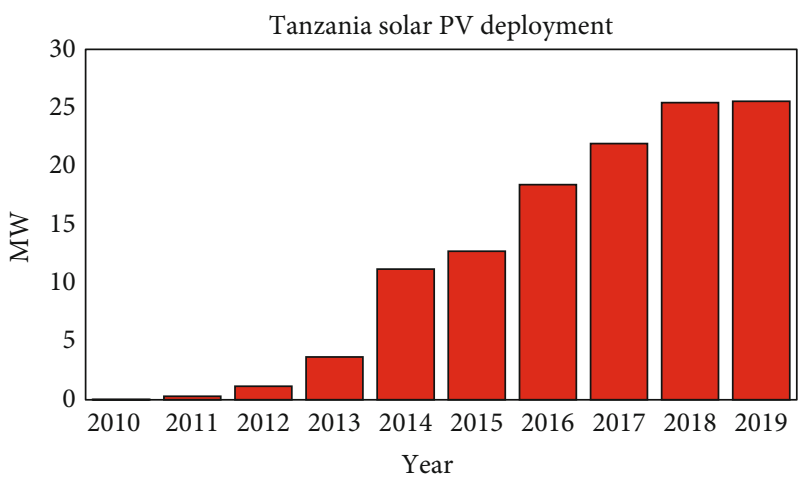

MW

Figure 24: Solar PV trends in Tanzania by IRENA.

radiation of 4.6 to $5.6 \mathrm{kWh}$ per $\mathrm{m}^{2}$ per day [14]. Burundi has an electricity access rate of $9.3 \%$ and is one of the seven countries with the least electricity access globally $[9,26]$. The energy institutional structure in Burundi is greatly constrained. It is composed of "Regideso" which is the national utility. The national utility has a mandate for power generation, transmission, and distribution with a 25 -year legal monopoly renewed in 2015 [9]. Regideso owns and operates the generation assets made up of 8 hydroelectric and 2 thermal plants producing a total of $45.0 \mathrm{MW}$ for nearly 10 million people. Most of the grid infrastructure is very old and incapable to handle any additional grid power [47].

There are a few Independent Power Producers (IPPs), providing electricity mainly for their own needs [47]. On policy and institutional efforts, the Decentralized Rural Electrification Strategy (2015-2017) outlines approaches of decentralizing renewable energy by establishing institutional, community, commercial level structures, and building capacity. Under the electrification strategy, there are intentions to create a National Agency for Renewable Energy and Energy Efficiency. Under Burundi's vision 2025 approved in 2011, the government is aimed at achieving an electrification rate of $25.0 \%$ by 2025 by developing renewable micro and mini plants. The government introduced tax exemptions for PV modules and generators. "Solar Electricity service with Mini-Grids in Africa-Burundi" (SESMA-Burundi) is working on the construction of about 7 initial minigrids [48]. Table 13 describes the institutions involved in the Burundi energy sector.

According to the IRENA, solar PV deployment in Burundi produced a total of $5.103 \mathrm{MW}$ as can be shown by 
TABLE 11: Institutions involved in the energy sector in Tanzania.

\begin{tabular}{|c|c|c|}
\hline Institution & Mandate & Ref \\
\hline $\begin{array}{l}\text { Tanzania Electricity Supply } \\
\text { Company (TANESCO) }\end{array}$ & $\begin{array}{l}\text { Manages electricity generation, transmission, and distribution. } \\
\text { It also owns most of the assets. }\end{array}$ & {$[42]$} \\
\hline Rural Energy Agency (REA) & $\begin{array}{l}\text { A government organization that manages the Rural Energy } \\
\text { Fund (REF). It executes the rural electrification strategy } \\
\text { through the central grid and off-grid solutions. }\end{array}$ & {$[43,44]$} \\
\hline $\begin{array}{l}\text { Ministry of Energy formerly Ministry of } \\
\text { Energy and Minerals }\end{array}$ & Develops policies affecting energy in Tanzania & [39] \\
\hline $\begin{array}{l}\text { Energy and Water Utilities Regulation } \\
\text { Authority (EWURA) }\end{array}$ & $\begin{array}{l}\text { Regulates the generation, transmission, and distribution of } \\
\text { electricity. Sets and approves tariffs and other management tools. }\end{array}$ & {$[45]$} \\
\hline Small Power Producers (SPP) & $\begin{array}{c}\text { Independent power producers of capacity less than } 10 \mathrm{MW} \text {. They } \\
\text { provide } 2.0 \% \text { of the total power to TANESCO. }\end{array}$ & {$[45]$} \\
\hline Independent Power Producers (IPP) & Provide $26.0 \%$ of total TANESCO capacity & {$[46]$} \\
\hline Emergency Power Producers & Provide $13.0 \%$ of total TANESCO capacity & {$[40]$} \\
\hline
\end{tabular}

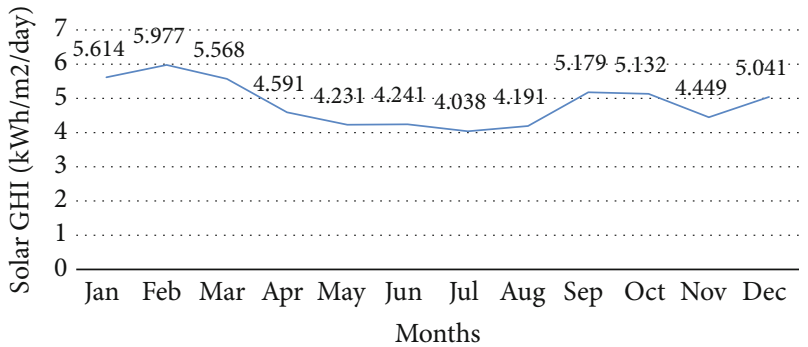

FIGURE 25: Monthly solar Global Horizontal Irradiation (GHI $\mathrm{kWh} / \mathrm{m}^{2} /$ day) for Tanzania.

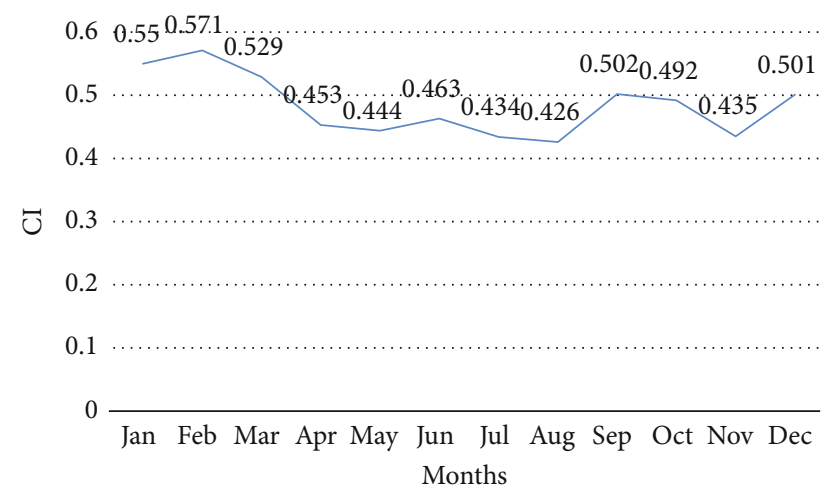

FIgURE 26: Monthly clearness index (CI) for Tanzania.

Figure 29, by the end of 2019 [26]. While minigrids are not a novel concept, solar PV minigrids are fairly new to the Burundi market and are very few. Figure 29 indicates solar PV trends in Burundi. The solar PV deployment was about $0.66 \mathrm{MW}$ in $2010,0.79 \mathrm{MW}$ in $2011,1.58 \mathrm{MW}$ in 2012, $2.64 \mathrm{MW}$ in 2013, 2.81 MW in $2014,3.10 \mathrm{MW}$ in $2015,4.09$ in 2016, 5.07 MW in 2017, 5.07 in 2018, and 5.07 in 2019, respectively.

Solar PV technologies experienced steady growth between 2010 and 2017(Figure 10). There was no significant growth between 2017 and 2019; however, plans are underway for an inaugural, megawatt-scale $(8.67 \mathrm{MW})$ solar PV mini-

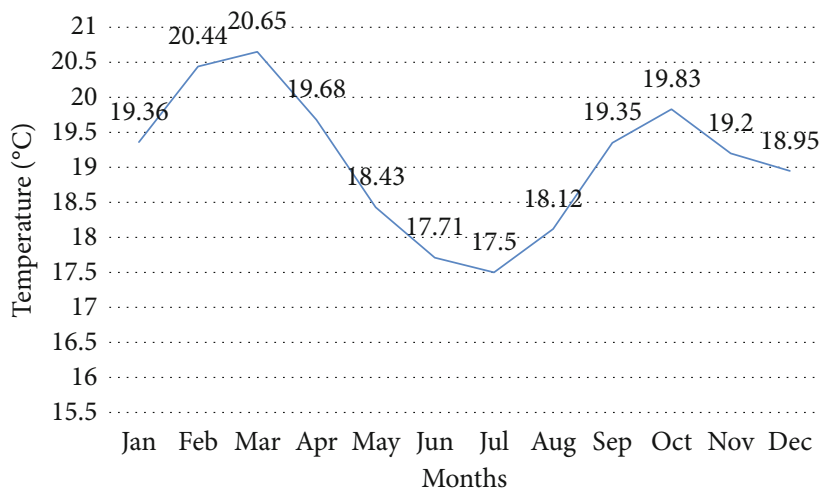

Figure 27: Monthly temperature variation $\left({ }^{\circ} \mathrm{C}\right)$ for Tanzania.

grid set to commence construction in 2020 [52]. This solar PV power plant is anticipated to increase the country's generation capacity by more than $10.0 \%$. The development will also be the first grid-connected solar project by an independent power producer (IPP) in Burundi. The project is a public-private partnership between the Government of Burundi and a private corporation. This project has a great demonstration impact to build capacity and give impetus to the minigrid market. Ongoing donor-financed infrastructure operations are assisting the Government of Burundi in funding the electrification of households, small businesses, schools, and health centers in rural areas using minisolar grids which will generate a total capacity of 17.0 MW [53]. The Government of Burundi will install solar minihybrid grids in rural areas. These solar minigrids will be equipped with battery storage systems and generators. Host sites totaling 150 have already been identified across the country. Figure 30 indicates the monthly solar global horizontal irradiation (GHI) for Burundi. The GHI rose from $4.674 \mathrm{kWh} / \mathrm{m}^{2} /$ day in January to $4.928 \mathrm{kWh} / \mathrm{m}^{2} /$ day in February and $4.988 \mathrm{kWh} / \mathrm{m}^{2} /$ day in March. The GHI then decreased to $4.446 \mathrm{kWh} / \mathrm{m}^{2} /$ day in April, $4.447 \mathrm{kWh} / \mathrm{m} 2 /$ day in May, and rose to $4.936 \mathrm{kWh} / \mathrm{m}^{2} /$ day in June, $5.159 \mathrm{kWh} / \mathrm{m}^{2} /$ day in July to peak at $5.425 \mathrm{kWh} / \mathrm{m}^{2} /$ day in August. It declined to $5.198 \mathrm{kWh} / \mathrm{m}^{2} /$ day in September, $4.881 \mathrm{kWh} / \mathrm{m}^{2} /$ day in 


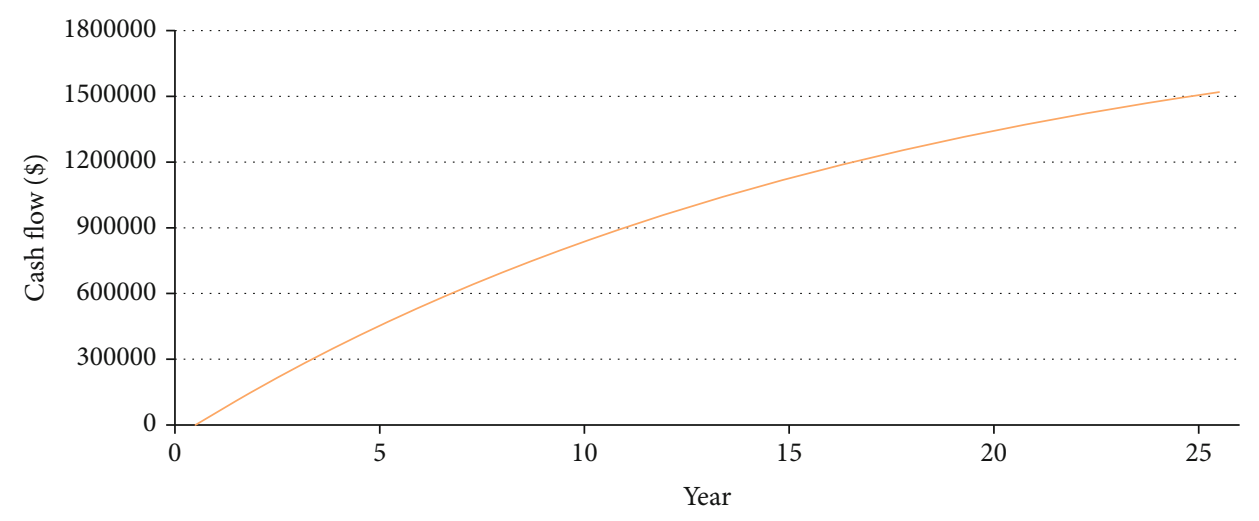

FIGURE 28: Cumulative cash flows over project lifetime Tanzania.

October, and $4.442 \mathrm{kWh} / \mathrm{m}^{2} /$ day in November (lowest) before rising to $4.659 \mathrm{kWh} / \mathrm{m}^{2} /$ day in December.

Figure 31 depicts the monthly clearness index (CI) for Burundi. The CI increased from 0.449 in January to 0.465 in February, 0.474 in March, and declines to 0.443 in April. It rose again to 0.476 in May, 0.553 in June, 0.568 in July, and 0.560 in August, down to 0.506 in September, 0.464 in October, and to the least at 0.425 in November before rising to 0.453 in December.

Figure 32 indicates the monthly temperature variation for Burundi. The temperature rose from $19.95^{\circ} \mathrm{C}$ in January to $20.30^{\circ} \mathrm{C}$ in February, down to $20.23^{\circ} \mathrm{C}$ in March, $19.85^{\circ} \mathrm{C}$ in April, $19.85^{\circ} \mathrm{C}$ in May, $18.36^{\circ} \mathrm{C}$ in June, and to the least at $18.27^{\circ} \mathrm{C}$ in July. The temperature rose again to 19.60 in August to peak at $20.84^{\circ} \mathrm{C}$ in September, down to $20.73^{\circ} \mathrm{C}$ in October, and $19.93^{\circ} \mathrm{C}$ in November.

Figure 33 denotes the cumulative cash flows over project lifetimes for both the current and proposed power systems for Burundi. The current power system cumulative cash flows seem to be preferable to the proposed power system for Burundi because the area under the curve is larger than that of the proposed power system. The cash flow was zero at inception for the current power system but around US $\$ 898,265.90$ for the proposed power system. But at 7.33 years, both the current and proposed power systems cash flows were the same at US\$1,845,086.71. At their 25-year economic lives, the cumulative cash flows for both the current and proposed power systems were US $\$ 4,078,612.72$ and US $\$ 2,937,572.25$, respectively. If we use the areas under each curve, US $\$ 50,982,659.00$ and US $\$ 47,947,976.88$ were the cumulative cash flows for both the current and proposed power systems, respectively. Therefore, the current power system cumulative cash flows were US $\$ 3,034,682.12$ greater and better than those of the proposed power system.

Figure 34 indicates the categorized annual savings of the proposed power system for Burundi. The energy value amount was US $\$ 159,888.00$, operations and maintenance costs were US\$-1,057.00, and annual savings were US\$158,831.00.

Figure 35 depicts the monthly utility bills for both the current and proposed power systems for Burundi. The January utility bills for both the current and proposed power systems were US\$26,894.74 and US\$14,184.21, respectively. The
February utility bills for both the current and proposed power systems were US $\$ 24,131.58$ and US\$11,973.68, respectively. The March utility bills for both the current and proposed power systems were US $\$ 26,897.74$ and US $\$ 12,894.74$, respectively. The April utility bills for both the current and proposed power systems were US\$ $25,973.68$ and US\$13,631.58, respectively. The May utility bills for both the current and proposed power systems were US $\$ 26,894.74$ and US $\$ 14,000.00$, respectively. The June utility bills for both the current and proposed power systems were US $\$ 25,789.47$ and US $\$ 12,157.90$, respectively. The July utility bills for both the current and proposed power systems were US $\$ 26,894.74$ and US $\$ 11,973.68$, respectively. The August utility bills for both the current and proposed power systems were US $\$ 26,894.74$ and US $\$ 11,605.26$, respectively. The September utility bills for both the current and proposed power systems were US $\$ 25,900.00$ and US $\$ 12,157.90$, respectively. The October utility bills for both the current and proposed power systems were US\$26,894.74 and US $\$ 11,421.05$, respectively. The November utility bills for both the current and proposed power systems were US $\$ 25,789.47$ and US $\$ 14,368.42$, respectively. The December utility bills for both the current and proposed power systems were US $\$ 26,894.74$ and US\$14,110.53, respectively.

Table 14 depicts the utility annual bills and savings by category for Burundi. The base case consumption was US $\$ 316,820.00$ and that for the proposed power system was US\$156,932.00, while the annual savings were US $\$ 159,888.00$.

Figure 36 indicates the electrical production capacities for both the grid and proposed solar PV microgrid with storage for Burundi. The January electrical production capacities for both the current grid and proposed solar PV microgrid were 98.36 MWh and 45.25 MWh, respectively. The February electrical production capacities for both the current grid and proposed solar PV micro-grid were 90.49 MWh and 43.28 MWh, respectively. The March electrical production capacities for both the current grid and proposed solar PV microgrid were $100.33 \mathrm{MWh}$ and $49.18 \mathrm{MWh}$, respectively. The April electrical production capacities for both the current grid and proposed solar PV microgrid were 92.46 MWh and 43.28 MWh, respectively. The May electrical production capacities for both the current grid and proposed 


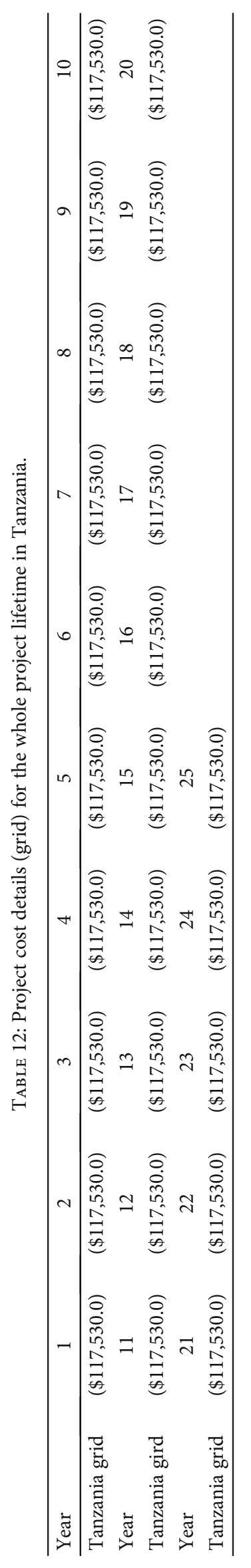


TABLE 13: Institutions involved in the energy sector in Burundi.

\begin{tabular}{|c|c|c|}
\hline Institution & Mandate & Ref \\
\hline Regideso & National utility that owns and manages Burundi's thermal and hydropower plants & [49] \\
\hline $\begin{array}{l}\text { Burundian Agency for Rural } \\
\text { Electrification (ABER) }\end{array}$ & $\begin{array}{l}\text { Planning, carrying out studies, and carrying out projects for electrification of rural centers, } \\
\text { villages. Regulates the electricity generation, transmission, and distribution. }\end{array}$ & [50] \\
\hline Ministry of Energy and Mines & $\begin{array}{l}\text { Oversees the development of policy and regulations of the energy sector. It coordinates sector } \\
\text { planning as well as for the management of the energy sector }\end{array}$ & [51] \\
\hline
\end{tabular}

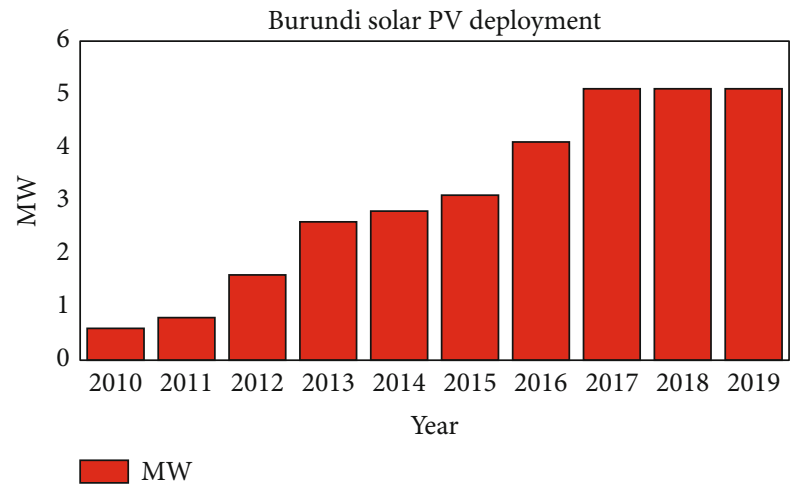

FIgURe 29: Solar PV trends in Burundi by IRENA.

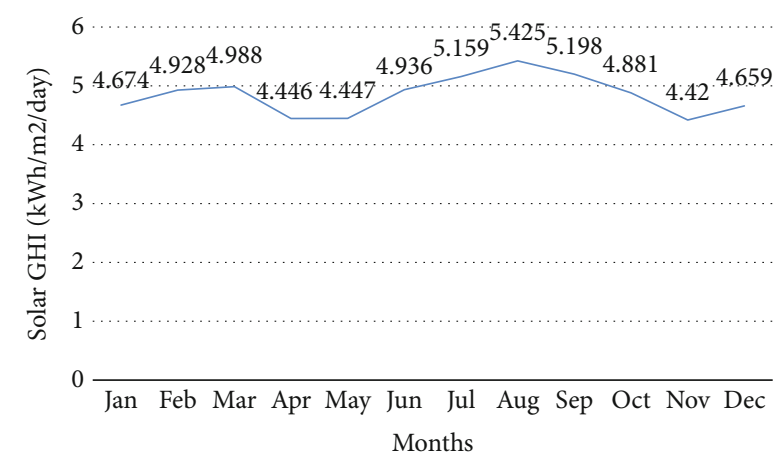

FIGURE 30: Monthly solar Global Horizontal Irradiation (GHI $\mathrm{kWh} / \mathrm{m}^{2} /$ day) for Burundi.

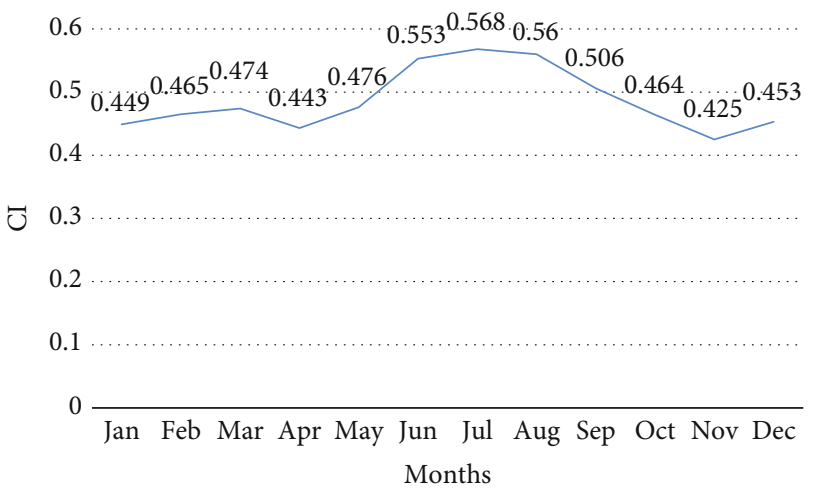

Figure 31: Monthly clearness index (CI) for Burundi.

solar PV micro-grid were 96.39 MWh and 45.25 MWh, respectively. The June electrical production capacities for both the current grid and proposed solar PV microgrid were

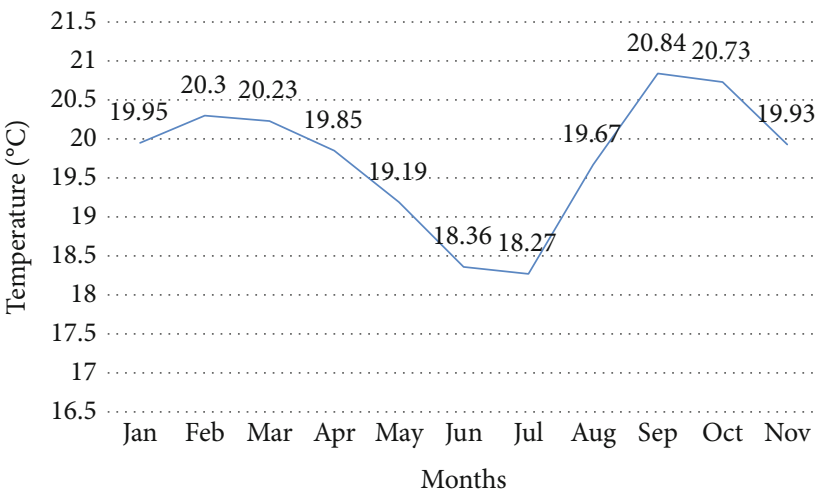

Figure 32: Monthly temperature variation $\left({ }^{\circ} \mathrm{C}\right)$ for Burundi.

95.41 MWh and 48.59 MWh, respectively. The July electrical production capacities for both the current grid and proposed solar PV microgrid were $100.00 \mathrm{MWh}$ and $52.52 \mathrm{MWh}$, respectively. The August electrical production capacities for both the current grid and proposed solar PV microgrid were 102.30 MWh and 55.08 MWh, respectively. The September electrical production capacities for both the current grid and proposed solar PV microgrid were 99.34 MWh and 50.16 MWh, respectively. The October electrical production capacities for both the current grid and proposed solar PV microgrid were $98.36 \mathrm{MWh}$ and $47.21 \mathrm{MWh}$, respectively. The November electrical production capacities for both the current grid and proposed solar PV micro-grid were 94.43 MWh and 41.31 MWh, respectively. The December electrical production capacities for both the current grid and proposed solar PV microgrid were 98.36 MWh and 45.25 MWh, respectively.

Furthermore, the solar PV system has a nominal capacity of $400.0 \mathrm{~kW}$, and its annual production was $567100.0 \mathrm{kWh} /$ year, and a specific yield of $1418.0 \mathrm{kWh} / \mathrm{kW}$.

Table 15 denotes the project cost details (both grid and solar PV systems) for the lifespan of the project in Burundi. The project cost for each year of the solar PV system was US $\$ 1,057.00$ while the yearly grid cost was US $\$ 156,932.00$, respectively.

Table 16 depicts the monthly utility summary for the current grid system for Burundi. The energy purchase was each US $\$ 86,800.00$ for January, March, May, July, August, October, and December, respectively. Only the February energy purchase was 78,400.00 kWh while those for April, June, September, and November were $84,000.0 \mathrm{kWh}$ each, respectively. The annual energy purchase was $1,022,000.0 \mathrm{kWh}$, and the total energy charge was US\$316,820.00. 


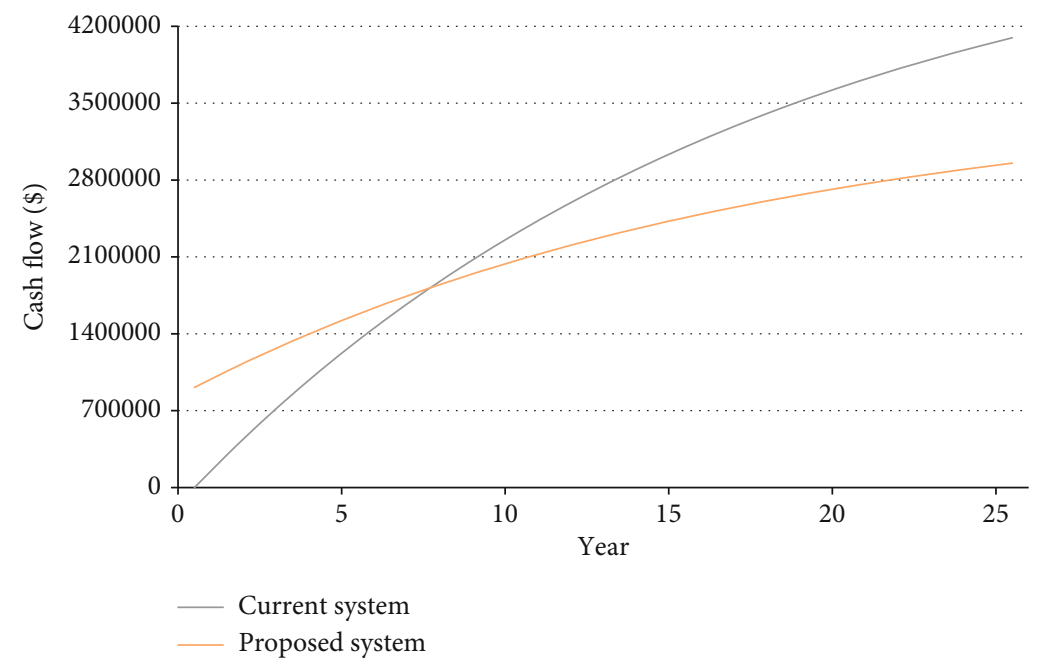

FIGURE 33: Cumulative cash flows over the project lifetime for the current and proposed systems for Burundi.

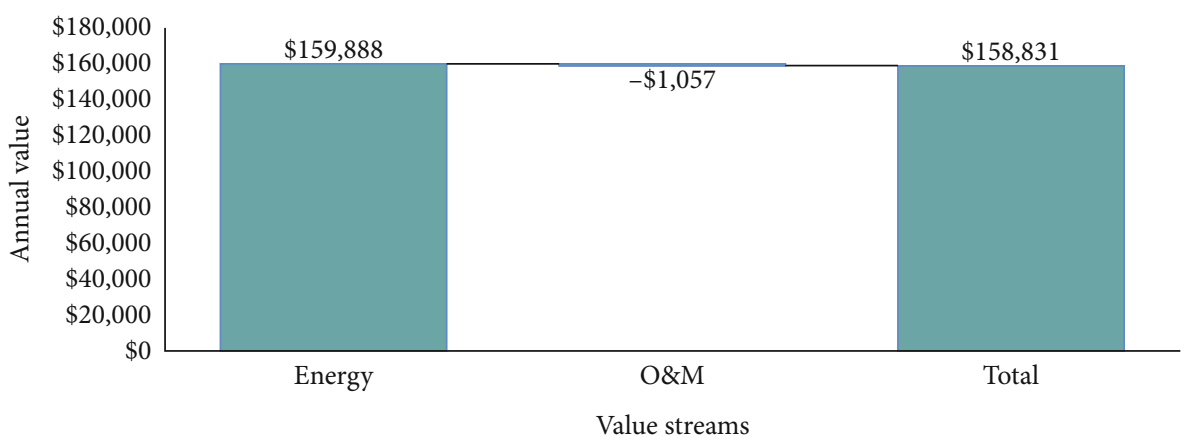

FIGURE 34: Categorized annual savings for the proposed system for Burundi.

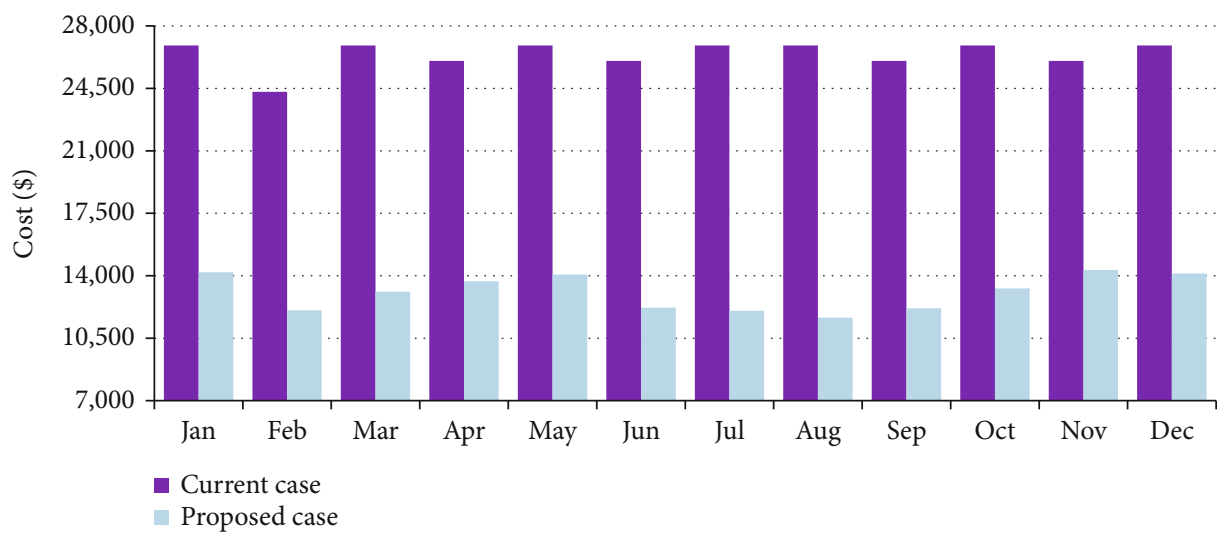

FIGURE 35: Monthly utility bills for the current and proposed systems for Burundi.

TABLE 14: Annual utility bills and savings by category (Burundi).

\begin{tabular}{lcc}
\hline & Consumption charge & Total \\
\hline Base case & $\$ 316,820.0$ & $\$ 316,820.0$ \\
Proposed case & $\$ 156,932.0$ & $\$ 156,932.0$ \\
Annual savings & $\$ 159,888.0$ & $\$ 159,888.0$ \\
\hline
\end{tabular}

Note: the base case is considered as the current system (grid connection) and the proposed case is the grid-connected solar PV microgrid with storage.
Table 17 indicates the monthly utility summary for the proposed power system from January to December for Burundi. The energy purchase, energy sold, and net energy for each of the months from January to December varied with the month. The annual energy purchase, annual energy sold, and net energy purchase were US\$600,892.00, US $\$ 145,992.00$, and US $\$ 454,000.00$, respectively. The peak load was $200.0 \mathrm{~kW}$ for each month, and the energy charge 


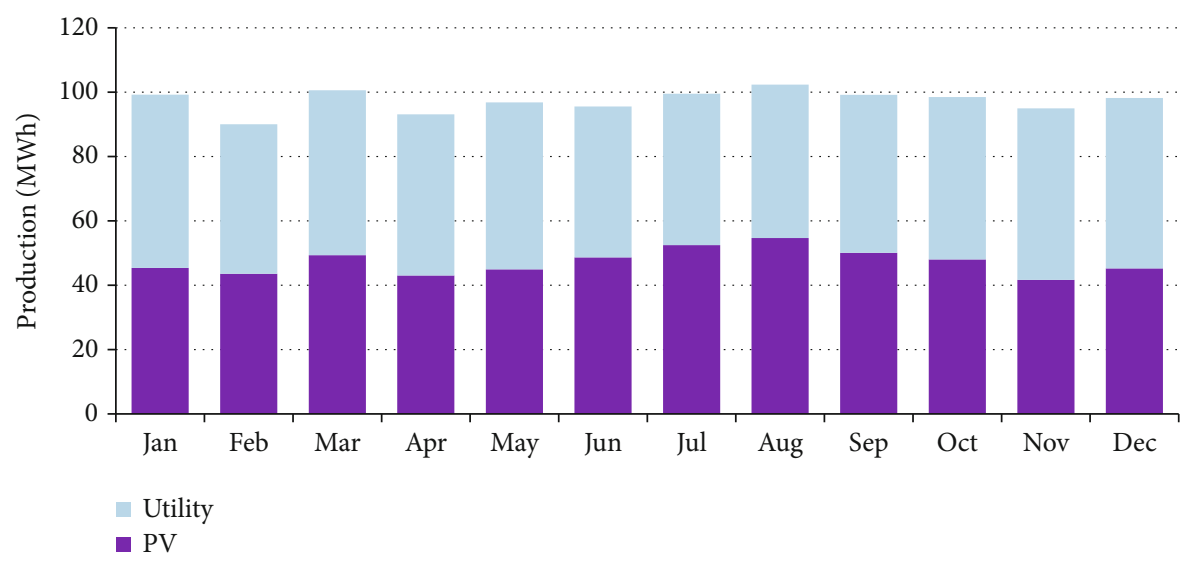

FIGURE 36: The electrical production for both utility and the solar PV microgrid for the proposed technology on Burundi.

varied with every month of the year. Furthermore, the fixed charge, minimum charge, demand charge, and taxes were each zero, respectively.

4.1.5. South Sudan. South Sudan enjoys between 1899 and 2264 quality sunshine hours annually with global horizontal radiation of 5.2 to $6.2 \mathrm{kWh}$ per $\mathrm{m}^{2}$ per day [14]. This is a valuable resource that can be utilized to bring electricity to the countryside. South Sudan has an electricity access rate of around $1.1 \%$ [22]. The energy sector in South Sudan is very limited constituting the national utility South Sudan Electricity Corporation (SSEC), the regulatory authority, and the ministry of electricity and dams. There was no transmission infrastructure or any interconnected grid network in South Sudan [54]. South Sudan's installed power capacity was approximately 130 megawatts by 2013, a large portion of which is used to supply electricity for extracting and processing petroleum oil. However, the country's power demand was about 300 megawatts in 2013 [54]. Currently, most of the solar energy deployed is stand-alone PV systems used to supply approximately 40,000 households to power a variety of electrical devices. The country's high insolation could be exploited to generate more electricity but this is still in the planning phase. Table 18 describes the institutions involved in the energy sector in South Sudan.

Solar minigrid deployment in South Sudan is still at the initial level. South Sudan's national utility completed technical evaluations for a 20-megawatt minigrid solar farm in Nesitu County and 35 megawatt-hour battery storage system planned outside of Juba [58]. The project is funded by a commercial bank. It will be the first grid-connected, megawattscale solar power plant in the country. According to the International Renewable Energy Agency (IRENA), South Sudan had installed a paltry $0.649 \mathrm{MW}$ of solar by the end of 2019 as shown in Figure 37, most of it off-grid capacity [26]. The sector was stagnant up to 2015 but experienced major growth in 2016 when solar PV installations doubled. Since then, there has been a gradual increase in the installation of solar PV technologies in South Sudan. Figure 37 depicts the South Sudan solar PV deployment from 2010 to 2019 (inclusive). The solar power was $0.16 \mathrm{MW}$ in 2012 up to and including 2015, 0.43 MW in 2016, $0.44 \mathrm{MW}$ in 2017, $0.55 \mathrm{MW}$ in 2018 , and $0.64 \mathrm{MW}$ in 2019 , respectively.

There are efforts to disseminate about 6800 solar irrigation pumps to rural households in a period stretching between 2012 and 2025. On completion, access of rural households to solar electricity will be at $10.0 \%$ [55]. Solar PV installations by several private companies are being used to provide electricity in smaller configurations through minigrids for personal use or clustered population. Some companies are using containerized off-grid solar battery hybrid power systems successfully installed in the southern part of South Sudan. These containerized solar PV minigrids (as can be shown in Figure 38) provide electricity to surrounding populations and institutions [13].

With the absence of a transmission backbone, all electricity in South Sudan is essentially self-generated, largely by diesel generators. Currently, solar minigrids among other solar technologies are being actively initiated and funded by donors for demonstrational purposes of solar PV technology. The country has the least capacity of solar PV installed in the East Africa region compared to the other five member states. The country is yet to adopt a national electrification strategy that can give a road map into the future and attract significant investments. Figure 39 indicates the monthly solar global horizontal irradiation (GHI) in South Sudan. The GHI increased from $5.827 \mathrm{kWh} / \mathrm{m}^{2} /$ day in January to $6.112 \mathrm{kWh} / \mathrm{m}^{2} /$ day in February, $6.137 \mathrm{kWh} / \mathrm{m}^{2} /$ day in March, and $6.349 \mathrm{kWk} / \mathrm{m}^{2} /$ day (peak) in April. It increased to $5.497 \mathrm{kWh} / \mathrm{m}^{2} /$ day in May, $5.024 \mathrm{kWh} / \mathrm{m}^{2} /$ day in June, and $4.663 \mathrm{kWh} / \mathrm{m}^{2} /$ day in July (lowest). It rose gradually to $4.909 \mathrm{kWh} / \mathrm{m}^{2} /$ day in August, $5.277 \mathrm{kWh} / \mathrm{m}^{2} /$ day in September, $5.405 \mathrm{kWh} / \mathrm{m}^{2} /$ day in October, $5.900 \mathrm{kWh} / \mathrm{m}^{2} /$ day in November, and $5.766 \mathrm{kWh} / \mathrm{m}^{2} /$ day.

Figure 40 is the monthly clearness index (CI) for South Sudan. The CI decreased from 0.64 in January to 0.63 in February, 0.59 in March, 0.60 in April, 0.53 in May, 0.50 in June, 0.46 in July (lowest), 0.47 in August, 0.50 in September, 0.55 in October, 0.64 in November, and 0.65 in December.

Figure 41 shows the monthly temperature variation for South Sudan. The temperature increased from $29.11^{\circ} \mathrm{C}$ in January to $30.85^{\circ} \mathrm{C}$ in February, $32.53^{\circ} \mathrm{C}$ in March, $32.37^{\circ} \mathrm{C}$ 


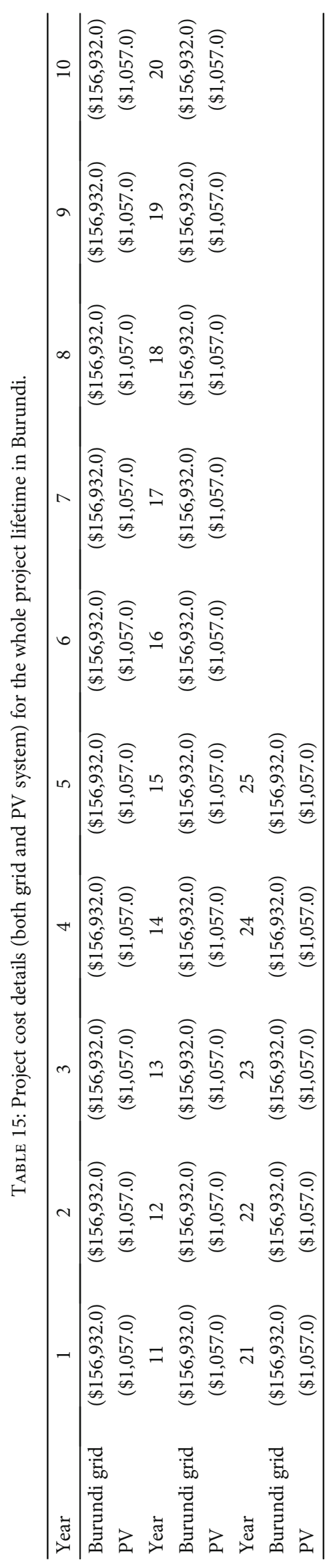


TABLE 16: Utility monthly summary—current system (Burundi).

\begin{tabular}{|c|c|c|c|c|c|c|c|c|c|c|}
\hline Month & $\begin{array}{c}\text { Energy } \\
\text { purchased } \\
(\mathrm{kWh})\end{array}$ & $\begin{array}{l}\text { Energy sold } \\
\quad(\mathrm{kWh})\end{array}$ & $\begin{array}{c}\text { Net energy } \\
\text { purchased (kWh) }\end{array}$ & $\begin{array}{l}\text { Peak load } \\
(\mathrm{kW})\end{array}$ & $\begin{array}{l}\text { Energy } \\
\text { charge }\end{array}$ & $\begin{array}{l}\text { Demand } \\
\text { charge }\end{array}$ & $\begin{array}{l}\text { Fixed } \\
\text { charge }\end{array}$ & $\begin{array}{l}\text { Minimum } \\
\text { charge }\end{array}$ & Taxes & Total \\
\hline January & $86,800.0$ & 0.0 & $86,800.0$ & 200.0 & $\$ 26,908.0$ & $\$ 0.0$ & $\$ 0.0$ & $\$ 0.0$ & $\$ 0.0$ & $\$ 26,908.0$ \\
\hline February & $78,400.0$ & 0.0 & $78,400.0$ & 200.0 & $\$ 24,304.0$ & $\$ 0.0$ & $\$ 0.0$ & $\$ 0.0$ & $\$ 0.0$ & $\$ 24,304.0$ \\
\hline March & $86,800.0$ & 0.0 & $86,800.0$ & 200.0 & $\$ 26,908.0$ & $\$ 0.0$ & $\$ 0.0$ & $\$ 0.0$ & $\$ 0.0$ & $\$ 26,908.0$ \\
\hline April & $84,000.0$ & 0.0 & $84,000.0$ & 200.0 & $\$ 26,040.0$ & $\$ 0.0$ & $\$ 0.0$ & $\$ 0.0$ & $\$ 0.0$ & $\$ 26,040.0$ \\
\hline May & $86,800.0$ & 0.0 & $86,800.0$ & 200.0 & $\$ 26,908.0$ & $\$ 0.0$ & $\$ 0.0$ & $\$ 0.0$ & $\$ 0.0$ & $\$ 26,908.0$ \\
\hline June & $84,000.0$ & 0.0 & $84,000.0$ & 200.0 & $\$ 26,040.0$ & $\$ 0.0$ & $\$ 0.0$ & $\$ 0.0$ & $\$ 0.0$ & $\$ 26,040.0$ \\
\hline July & $86,800.0$ & 0.0 & $86,800.0$ & 200.0 & $\$ 26,908.0$ & $\$ 0.0$ & $\$ 0.0$ & $\$ 0.0$ & $\$ 0.0$ & $\$ 26,908.0$ \\
\hline August & $86,800.0$ & 0.0 & $86,800.0$ & 200.0 & $\$ 26,908.0$ & $\$ 0.0$ & $\$ 0.0$ & $\$ 0.0$ & $\$ 0.0$ & $\$ 26,908.0$ \\
\hline September & $84,000.0$ & 0.0 & $84,000.0$ & 200.0 & $\$ 26,040.0$ & $\$ 0.0$ & $\$ 0.0$ & $\$ 0.0$ & $\$ 0.0$ & $\$ 26,040.0$ \\
\hline October & $86,800.0$ & 0.0 & $86,800.0$ & 200.0 & $\$ 26,908.0$ & $\$ 0.0$ & $\$ 0.0$ & $\$ 0.0$ & $\$ 0.0$ & $\$ 26,908.0$ \\
\hline November & $84,000.0$ & 0.0 & $84,000.0$ & 200.0 & $\$ 26,040.0$ & $\$ 0.0$ & $\$ 0.0$ & $\$ 0.0$ & $\$ 0.0$ & $\$ 26,040.0$ \\
\hline December & $86,800.0$ & 0.0 & $86,800.0$ & 200.0 & $\$ 26,908.0$ & $\$ 0.0$ & $\$ 0.0$ & $\$ 0.0$ & $\$ 0.0$ & $\$ 26,908.0$ \\
\hline Annual & $1,022,000.0$ & 0.0 & $1,022,000.0$ & 200.0 & $\$ 316,820.0$ & $\$ 0.0$ & $\$ 0.0$ & $\$ 0.0$ & $\$ 0.0$ & $\$ 316,820.0$ \\
\hline
\end{tabular}

TABLE 17: Utility monthly summary-proposed system (Burundi).

\begin{tabular}{|c|c|c|c|c|c|c|c|c|c|c|}
\hline Month & $\begin{array}{c}\text { Energy } \\
\text { purchased } \\
(\mathrm{kWh})\end{array}$ & $\begin{array}{l}\text { Energy sold } \\
\quad(\mathrm{kWh})\end{array}$ & $\begin{array}{c}\text { Net energy } \\
\text { purchased (kWh) }\end{array}$ & $\begin{array}{l}\text { Peak load } \\
(\mathrm{kW})\end{array}$ & $\begin{array}{l}\text { Energy } \\
\text { charge }\end{array}$ & $\begin{array}{l}\text { Demand } \\
\text { charge }\end{array}$ & $\begin{array}{l}\text { Fixed } \\
\text { charge }\end{array}$ & $\begin{array}{l}\text { Minimum } \\
\text { charge }\end{array}$ & Taxes & Total \\
\hline January & $53,862.0$ & $12,446.0$ & $41,416.0$ & 200.0 & $\$ 14,195.0$ & $\$ 0.0$ & $\$ 0.0$ & $\$ 0.0$ & $\$ 0.0$ & $\$ 14,195.0$ \\
\hline February & $46,446.0$ & $11,618.0$ & $34,828.0$ & 200.0 & $\$ 12,063.0$ & $\$ 0.0$ & $\$ 0.0$ & $\$ 0.0$ & $\$ 0.0$ & $\$ 12,063.0$ \\
\hline March & $51,219.0$ & $13,778.0$ & $37,441.0$ & 200.0 & $\$ 13,108.0$ & $\$ 0.0$ & $\$ 0.0$ & $\$ 0.0$ & $\$ 0.0$ & $\$ 13,108.0$ \\
\hline April & $50,051.0$ & $9,091.0$ & $40,960.0$ & 200.0 & $\$ 13,689.0$ & $\$ 0.0$ & $\$ 0.0$ & $\$ 0.0$ & $\$ 0.0$ & $\$ 13,689.0$ \\
\hline May & $51,852.0$ & $10,005.0$ & $41,847.0$ & 200.0 & $\$ 14,063.0$ & $\$ 0.0$ & $\$ 0.0$ & $\$ 0.0$ & $\$ 0.0$ & $\$ 14,063.0$ \\
\hline June & $46,861.0$ & $11,534.0$ & $35,326.0$ & 200.0 & $\$ 12,208.0$ & $\$ 0.0$ & $\$ 0.0$ & $\$ 0.0$ & $\$ 0.0$ & $\$ 12,208.0$ \\
\hline July & $47,071.0$ & $12,718.0$ & $34,353.0$ & 200.0 & $\$ 12,036.0$ & $\$ 0.0$ & $\$ 0.0$ & $\$ 0.0$ & $\$ 0.0$ & $\$ 12,036.0$ \\
\hline August & $47,662.0$ & $15,557.0$ & $32,105.0$ & 200.0 & $\$ 11,648.0$ & $\$ 0.0$ & $\$ 0.0$ & $\$ 0.0$ & $\$ 0.0$ & $\$ 11,648.0$ \\
\hline September & $49,127.0$ & $15,184.0$ & $33,943.0$ & 200.0 & $\$ 12,177.0$ & $\$ 0.0$ & $\$ 0.0$ & $\$ 0.0$ & $\$ 0.0$ & $\$ 12,177.0$ \\
\hline October & $50,465.0$ & $11,700.0$ & $38,765.0$ & 200.0 & $\$ 13,292.0$ & $\$ 0.0$ & $\$ 0.0$ & $\$ 0.0$ & $\$ 0.0$ & $\$ 13,292.0$ \\
\hline November & $53,316.0$ & $10,977.0$ & $42,339.0$ & 200.0 & $\$ 14,322.0$ & $\$ 0.0$ & $\$ 0.0$ & $\$ 0.0$ & $\$ 0.0$ & $\$ 14,322.0$ \\
\hline December & $52,960.0$ & $11,383.0$ & $41,577.0$ & 200.0 & $\$ 14,130.0$ & $\$ 0.0$ & $\$ 0.0$ & $\$ 0.0$ & $\$ 0.0$ & $\$ 14,130.0$ \\
\hline Annual & $600,892.0$ & $145,992.0$ & $454,900.0$ & 200.0 & $\$ 156,932.0$ & $\$ 0.0$ & $\$ 0.0$ & $\$ 0.0$ & $\$ 0.0$ & $\$ 156,932.0$ \\
\hline
\end{tabular}

TABLE 18: Descriptions of institutions involved in the energy sector in South Sudan.

\begin{tabular}{lr}
\hline Institution & Mandate \\
$\begin{array}{l}\text { South Sudan Electricity Corporation } \\
\text { (SSEC) }\end{array}$ & $\begin{array}{c}\text { The national electric utility that oversees the generation, transmission, and supply of } \\
\text { electricity. }\end{array}$ \\
$\begin{array}{l}\text { South Sudan Electricity Regulation } \\
\text { Authority (SSERA) }\end{array}$ & $\begin{array}{r}\text { Functional energy regulator of South Sudan's minigrids. It administers license approval, sets } \\
\text { tariffs, and maintains technical standards. }\end{array}$ \\
$\begin{array}{l}\text { Ministry of Electricity and Dams } \\
\text { (MoED) }\end{array}$ & $\begin{array}{r}\text { MoED is responsible for the development of hydro dams for multipurpose use including } \\
\text { hydropower generation. It is also responsible for the development of renewable energies. } \\
\text { [5evelop policies, oversee compliance, and set tariffs. }\end{array}$ \\
\hline
\end{tabular}




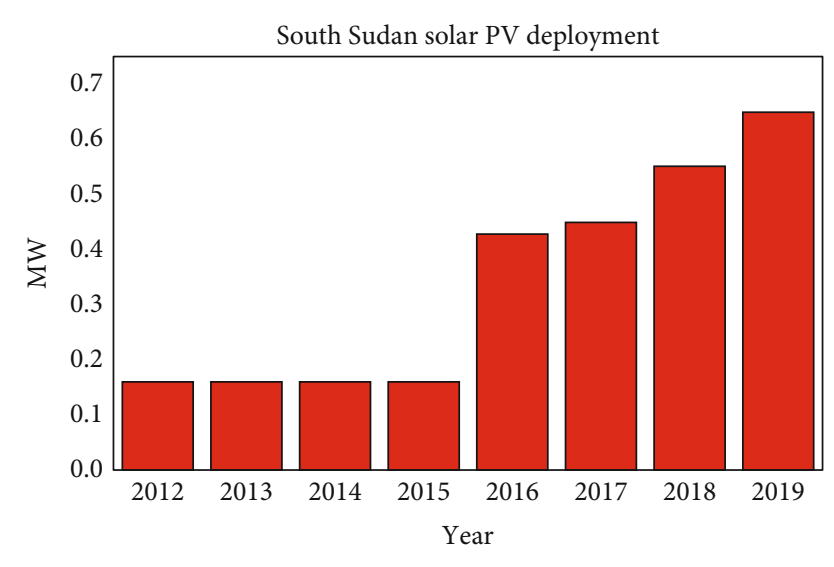

MW

FIgURe 37: Solar PV trends in South Sudan by IRENA.

in April, $29.95^{\circ} \mathrm{C}$ in May, $27.81^{\circ} \mathrm{C}$ in June, $26.09^{\circ} \mathrm{C}$ in July, $25.95^{\circ} \mathrm{C}$ in August, $26.71^{\circ} \mathrm{C}$ in September, $27.48^{\circ} \mathrm{C}$ in October, $28.71^{\circ} \mathrm{C}$ in November, and $28.89^{\circ} \mathrm{C}$ in December.

Figure 42 depicts the cumulative cash flows of the project lifespan for the current and proposed power systems for South Sudan. The areas under the cash flow curves show that the current grid power system was more profitable than the proposed power system because it had a smaller area. At inception, the current power system had zero cash flow while the proposed power system has US\$95,000.00 cash flow at the inception of the project. At the end of the project lifespan, the current grid system cash flow was US\$5,700,000.00, and the proposed power system cash flow was US\$3,300,000.00, respectively. The areas under both the current grid and proposed power systems were US\$71,250,000.00 and US $\$ 53,125,000.00$, respectively. That means that the current grid power system cash flow was US\$18,125,000.00 better than that of the proposed power system.

Figure 43 indicates the categorized annual savings of the proposed power system for South Sudan. The energy value was US\$254,973.00, US\$1,057.00 the operations and maintenance expense, and US\$253,917.00 energy savings for South Sudan, respectively.

Figure 44 depicts the monthly utility bills for the current and proposed power systems for South Sudan. The January bills for both the current and proposed power systems were US $\$ 37,285.71$ and US\$13,714.29, respectively. The February bills for both the current and proposed power systems were US $\$ 33,857.14$ and US\$12,000.00, respectively. The March bills for both the current and proposed power systems were US $\$ 37,285.71$ and US $\$ 13,214.29$, respectively. The April bills for both the current and proposed power systems were US $\$ 36,428.57$ and US\$13,285.71, respectively. The May bills for both the current and proposed power systems were US $\$ 37,285.71$ and US $\$ 17,142.86$, respectively. The June bills for both the current and proposed power systems were US $\$ 36,428.57$ and US $\$ 18,000.00$, respectively. The July bills for both the current and proposed power systems were US\$37,714.29 and US\$19,714.29, respectively. The August bills for both the current and proposed power systems were US\$37,714.29 and US\$18,857.14, respectively. The Septem- ber bills for both the current and proposed power systems were US\$36,000.00 and US\$16,714.29, respectively. The October bills for both the current and proposed power systems were US\$37,714.29 and US\$15,857.14, respectively. The November bills for both the current and proposed power systems were US $\$ 36,428.57$ and US $\$ 12,857.14$, respectively. The December bills for both the current and proposed power systems were US\$37,285.71 and US\$13,714.29, respectively.

Table 19 indicates the annual utility bills and savings by category for South Sudan. The base case electricity consumption was US $\$ 439,460.00$, US $\$ 184,487.00$ the proposed power system consumption charge, and US\$254,973.00 the annual savings, respectively.

Figure 45 denotes the electrical production capacities of both the current utility and the solar PV microgrid in South Sudan. The January electrical production capacities for both the current grid and proposed solar PV microgrid were 107.76 MWh and 62.45 MWh, respectively. The February electrical production capacities for both the current grid and proposed solar PV microgrid were $97.96 \mathrm{MWh}$ and 56.33 MWh, respectively. The March electrical production capacities for both the current grid and proposed solar PV microgrid were 107.76 MWh and 62.45 MWh, respectively. The April electrical production capacities for both the current grid and proposed solar PV microgrid were 102.86 MWh and 60.00 MWh, respectively. The May electrical production capacities for both the current grid and proposed solar PV microgrid were 100.00 MWh and 51.43 MWh, respectively. The June electrical production capacities for both the current grid and proposed solar PV microgrid were 93.06 MWh and 46.53 MWh, respectively. The July electrical production capacities for both the current grid and proposed solar PV microgrid were 95.50 MWh and 44.08 MWh, respectively. The August electrical production capacities for both the current grid and proposed solar PV microgrid were 97.96 MWh and 46.53 MWh, respectively. The September electrical production capacities for both the current grid and proposed solar PV microgrid were 99.18 MWh and 51.43 MWh, respectively. The October electrical production capacities for both the current grid and proposed solar PV microgrid were $102.86 \mathrm{MWh}$ and 55.10 MWh, respectively. The November electrical production capacities for both the current grid and proposed solar PV microgrid were 105.31 MWh and 61.22 MWh, respectively. The December electrical production capacities for both the current grid and proposed solar PV microgrid were 107.76 MWh and 62.45 MWh, respectively.

Further, the solar PV system has a nominal capacity of $400.0 \mathrm{~kW}$, and its annual production was $661886.0 \mathrm{kWh} /$ year, and a specific yield of $1655.0 \mathrm{kWh} / \mathrm{kW}$.

Table 20 reflects the project lifespan cost details for both the grid and solar PV microgrid systems for South Sudan. The solar PV system cost annually was US\$1,057.00 for 25 years, while grid cost per pear was US\$184,487.00 for the 25-year economic lifespan, respectively.

Table 21 depicts the utility monthly summary for the current grid power system for South Sudan.

The energy purchase for January, March, May, July, August, October, and December was each 86,800.0 kWh, 


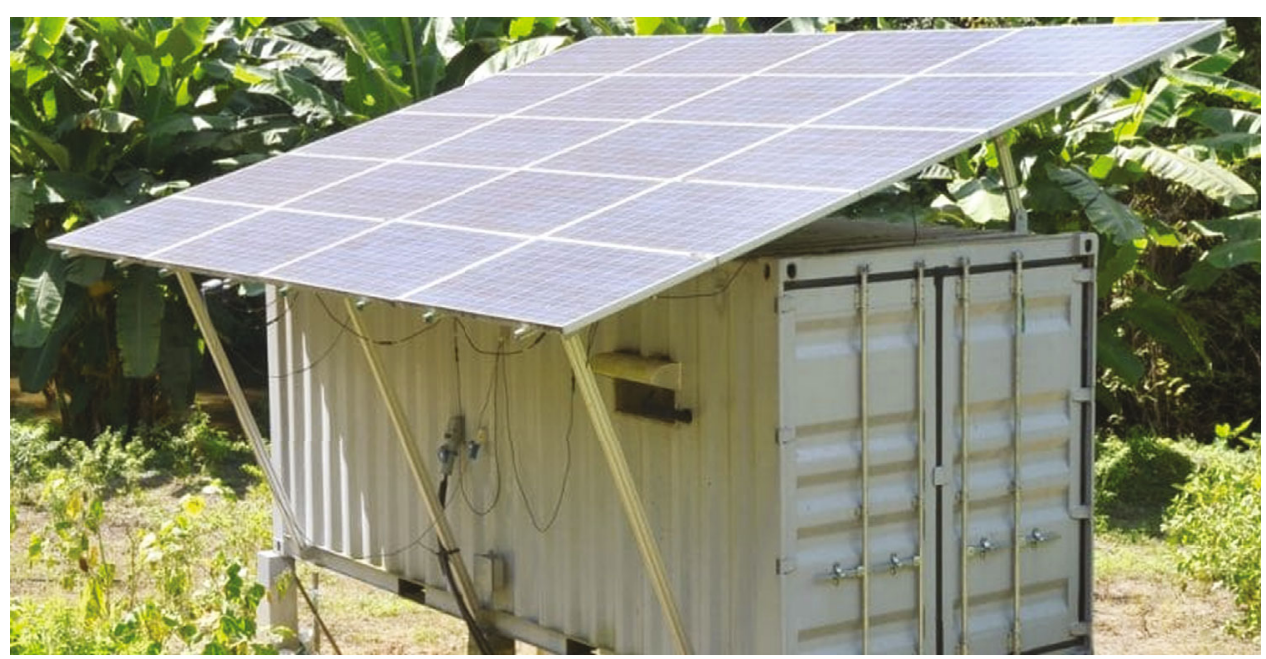

Figure 38: Image of a containerized minigrid system in South Sudan (Source: Aptech Africa).

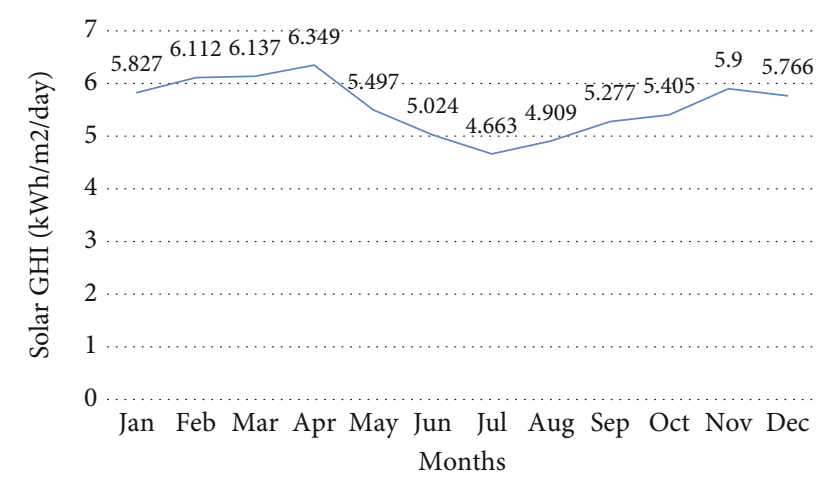

FIGURE 39: Monthly solar Global Horizontal Irradiation (GHI $\mathrm{kWh} / \mathrm{m}^{2} /$ day) for South Sudan.

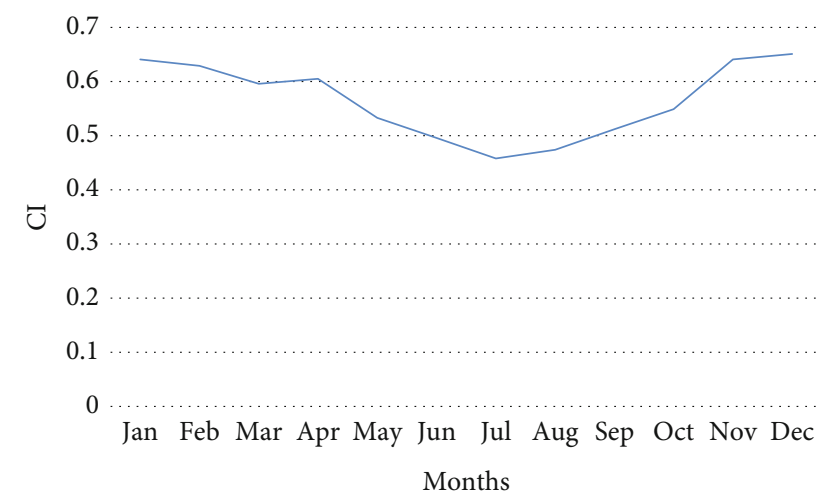

FIgURE 40: Monthly clearness index (CI) for South Sudan.

respectively. While only February was $78,400.0 \mathrm{kWh}$, the other months of April, June, September, and November were $84,000.0 \mathrm{kWh}$, respectively. The total energy purchase was $1,022,000.0 \mathrm{kWh}$, and the annual energy charge was US $\$ 439,460.00$, respectively.

Table 22 indicates the proposed power utility monthly summary for South Sudan. The energy purchased, energy sold, net energy purchase, and energy charge were each dif-

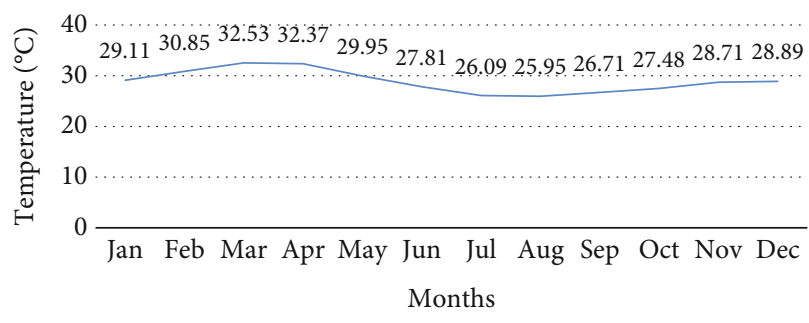

Figure 41: Monthly temperature variation $\left({ }^{\circ} \mathrm{C}\right)$ for South Sudan.

ferent for every month of the year. The total annual energy purchase was 555,099.0 kWh, 194,985.0 kWh annual energy sold, 360,114 kWh annual net energy purchase, and US\$184,487.00 energy charge, respectively. While $200.0 \mathrm{kWp}$ was the peak load, the demand charge, fixed charge, minimum charge, and taxes were zero each, respectively.

4.1.6. Rwanda. The minigrid sector in Rwanda has made some significant steps since 2017 but is still fairly young. Despite recent substantial financial support for privately owned and operated minigrids, the development of privately operated minigrids in Rwanda remains low. Harmonized efforts including the provision of funds through grants, access to credit, technical assistance, and an enabling regulatory framework are required to realize sector development [59].

The governments' rural electrification strategy has a target of $100.0 \%$ electrification by [60]. This includes $48.0 \%$ off-grid connections up from a current $14.0 \%[61,62]$. Currently, there are 84 minigrids in Rwanda with a total capacity of $250.0 \mathrm{~kW}$ (Rwanda Energy Group, 2019), slightly more than half of this capacity is supplied by solar PV minigrids (Table 6). Seventy-eight are in direct current (DC) while six are in alternating current (AC), 71 of these are solar PV minigrids. Rwanda has recently realized the commissioning of two solar AC minigrids and the addition of more DC minigrids operated by local developers. Table 23 describes the solar PV minigrids in Rwanda. 


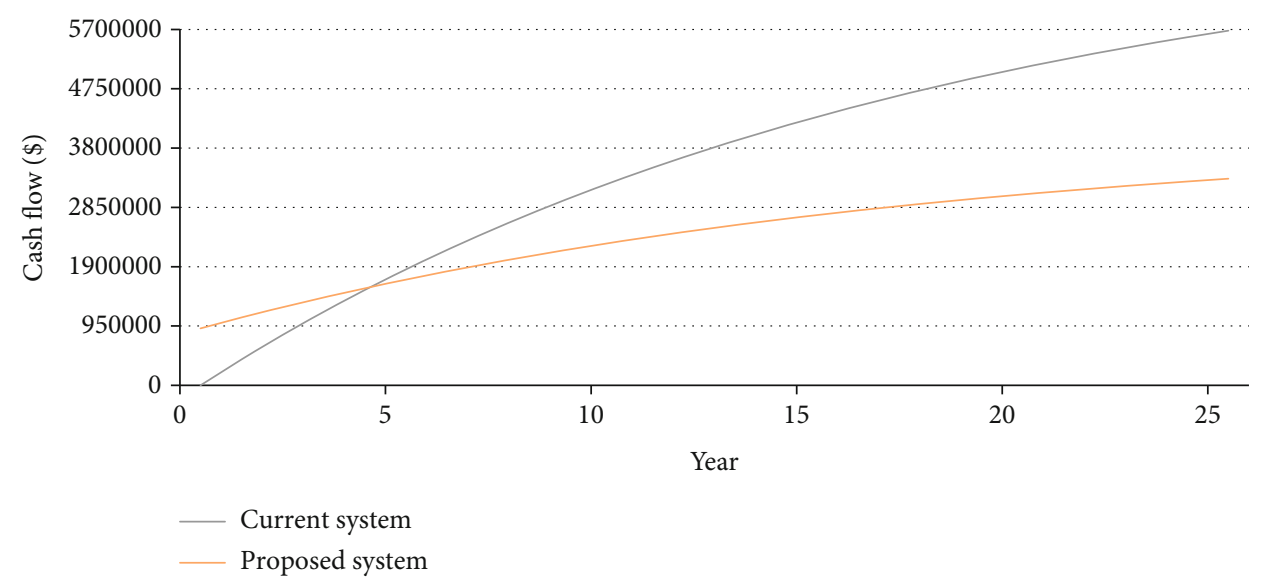

FIGURE 42: Cumulative cash flows over the project lifetime for the current and proposed systems for South Sudan.

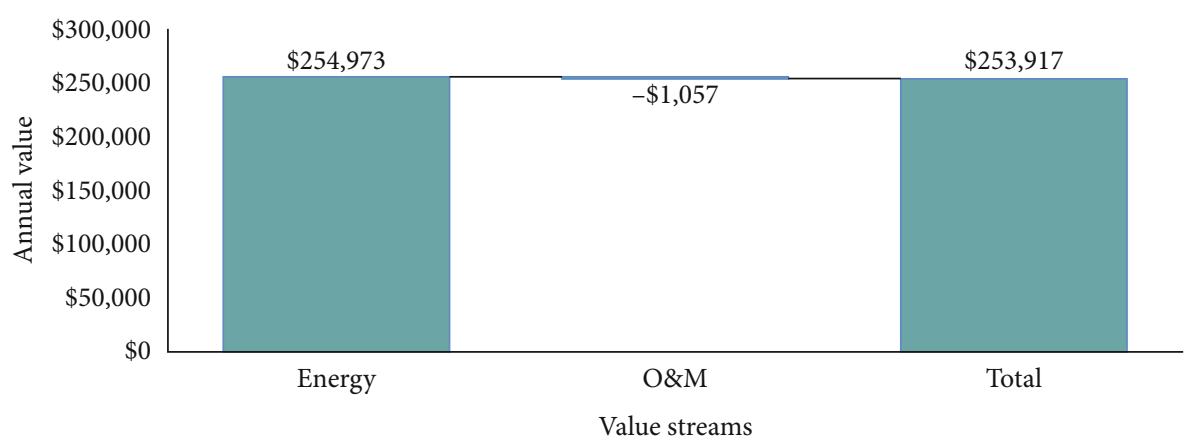

FIGURE 43: Categorized annual savings for a proposed system for South Sudan.

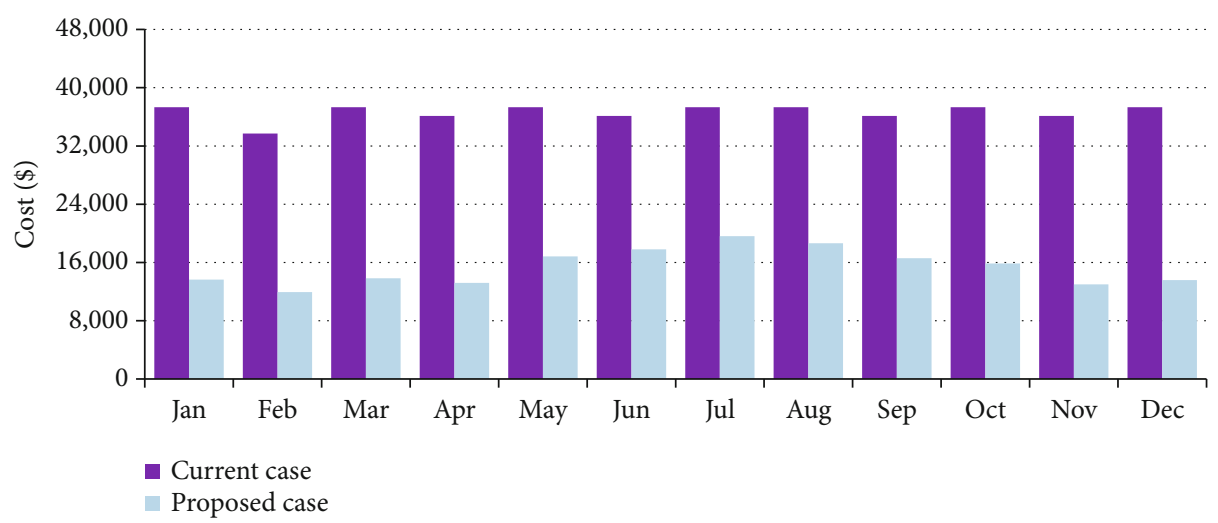

FIGURE 44: Monthly utility bills for the current and proposed systems for South Sudan.

TABle 19: Annual utility bills and savings by category (South Sudan).

\begin{tabular}{lcc}
\hline & Consumption charge & Total \\
\hline Base case & $\$ 439,460.00$ & $\$ 439,460.00$ \\
Proposed case & $\$ 184,487.00$ & $\$ 184,487.00$ \\
Annual savings & $\$ 254,973.00$ & $\$ 254,973.00$ \\
\hline
\end{tabular}

Note: the base case is considered as the current system (grid connection) and the proposed case is the grid-connected solar PV microgrid with storage.
In the face of a very low number of minigrids, there is a rising interest by private developers. At least two AC minigrids are in the planning phase while technical support has been offered to support another 37 isolated minigrid, both projects are funded by international agencies [59]. Furthermore, through a combination of financiers, 200 locations have been identified as feasible sites for minigrid development. The funds will also be used to provide advanced feasibility studies for up to 20 sites.

Existing privately-owned minigrids in Rwanda employ both AC and DC solar PV. The power is mainly supplied to 


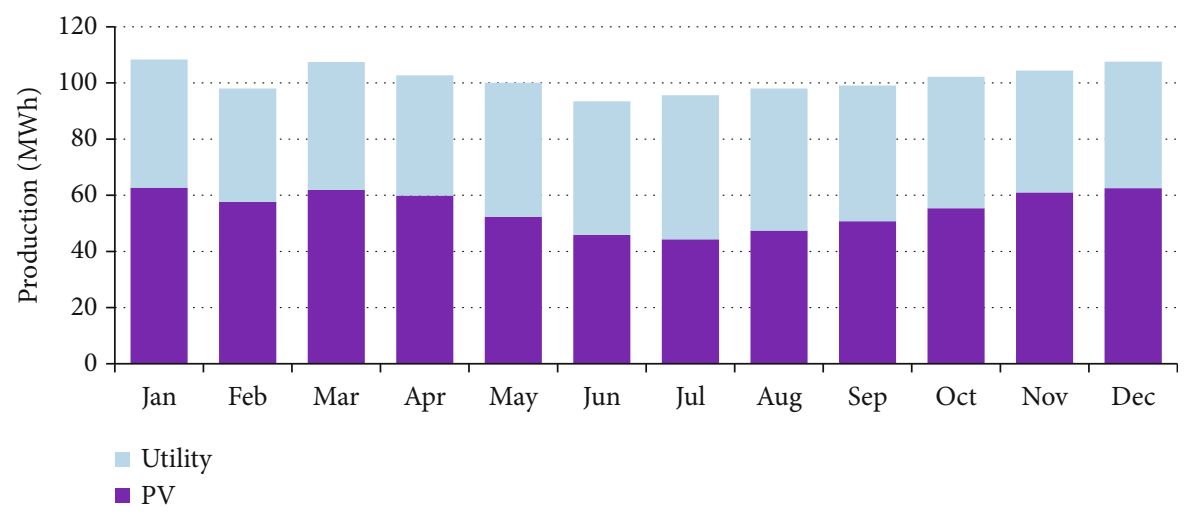

Figure 45: The electrical production for both utility and the solar PV microgrid for the proposed technology in South Sudan.

households, supplemented by few businesses and social institutions. The viability gap in Rwanda is wide with purchase power remaining very low, and the average household demand is between $2.0 \mathrm{kWh}$ and $7.0 \mathrm{kWh}$ per month [31, 60]. Consumption does not increase organically without additional support on the demand side. Some developers using DC grids face relatively low upfront costs as well as operation and maintenance compared to AC developers where the upfront costs are significantly higher, therefore, demanding a specific level of demand to ensure viability. High capital cost, coupled with minimal consumption, means most business models are not able to get commensurate returns without using a tariff that would appear exorbitant for the rural customers. Therefore, the creation of income-generating activities for end users is critical for the success of minigrid [63]. Minigrid construction in Rwanda requires support ranging between $40.0 \%$ and $70.0 \%$ of capital funding $[60,64,65]$, with most operating and upcoming projects either focusing on individual sites or testing business models to be up-scaled later. Minigrid financing in Rwanda is still heavily dependent on grants.

Figure 46 denotes the solar PV deployment in Rwanda between 2010 and 2019 (inclusive). The PV deployment in Rwanda was about $0.20 \mathrm{MW}$ for both 2010 and 2011, respectively; 0.33 MW in 2012; 1.00 MW in 2013; 9.67 MWin 2014; 13.67 MW in 2015; $18.67 \mathrm{MW}$ in $2016 ; 26.33$ in 2017; and $36.67 \mathrm{MW}$ both in 2018 and 2019, respectively.

According to the International Renewable Energy Agency (IRENA) and as shown in Figure 46 [26], Rwanda is the third most vibrant market for solar PV technologies in the East African community. It had installed $37.50 \mathrm{MW}$ by the end of 2019 despite having no significant growth from the previous year [26]. Before 2013, solar PV technology deployment was stagnant but since 2014 there have been installations of at least 4.0 MW per year until 2018 .

Rwanda Utility Regulation Authority (RURA) utilizes a simplified licensing structure for isolated renewable power stations which provides an affirmative legal framework to the sector. Developers are required to secure a "simplified electricity license" for small off-grids that, at the time of commissioning or subsequent expansion, have collective power production of between $50.0 \mathrm{~kW}$ and $1000.0 \mathrm{~kW}$. Similarly, power distribution networks that, during commission- ing or after expansion, have a capacity of at least 1.0 MW require a license [66]. The tariff is set by the developer at a level allowing capital recovery and a satisfactory return with necessary review from RURA. Minigrids of less than $50.0 \mathrm{~kW}$ are exempt from the licensing procedure but must notify the authorities. The Regulatory Authority (RURA) requires a separate license for each small isolated minigrid or small power distributor facility and does not consider the total of net generation capacity as the basis for determining whether the minigrid is classified as a small isolated minigrid. Table 24 indicates the institutions involved in the energy sector in Rwanda.

Figure 47 reflects the monthly solar Global Horizontal Irradiation (GHI) for Rwanda. The Rwanda GHI rose from $4.894 \mathrm{kWh} / \mathrm{m}^{2} /$ day in January to $4.923 \mathrm{kWh} / \mathrm{m}^{2} /$ day in February and down to $4.873 \mathrm{kWh} / \mathrm{m}^{2} /$ day in March $4.557 \mathrm{kWh} / \mathrm{m}^{2} /$ day in April, $4.457 \mathrm{kWh} / \mathrm{m}^{2} /$ day (lowest) in May, and rose again to $5.008 \mathrm{kWh} / \mathrm{m}^{2} /$ day in June, $5.348 \mathrm{kWh} / \mathrm{m}^{2} /$ day in July (peak). It declined to $5.311 \mathrm{kWh} / \mathrm{m}^{2} /$ day in August, $5.178 \mathrm{kWh} / \mathrm{m}^{2} /$ day in September, $5.010 \mathrm{kWh} / \mathrm{m}^{2} /$ day in October, $4.636 \mathrm{kWh} / \mathrm{m}^{2} /$ day in November, and rose to $4.780 \mathrm{kWh} / \mathrm{m}^{2} /$ day in December.

Figure 48 indicates the monthly clearness index (CI) for Rwanda. The CI decreased from 0.477 in January to 0.468 in February in March, 0.451 in April, 0.470 in May, and rose to 0.551 in June, 0.579 (peak) in July, and drops to 0.543 in August, 0.502 in September, 0.479 in October, 0.451 in November, and rose to 0.472 in December.

Figure 49 depicts the monthly temperature variation for Rwanda. The temperature rose from $19.99^{\circ} \mathrm{C}$ in January to $20.59^{\circ} \mathrm{C}$ in February (peak) and declines to $20.20^{\circ} \mathrm{C}$ in March, $19.34^{\circ} \mathrm{C}$ in April, $18.81^{\circ} \mathrm{C}$ in May, $18.66^{\circ} \mathrm{C}$ in June, $18.75^{\circ} \mathrm{C}$ in July, $19.83^{\circ} \mathrm{C}$ in August, and $20.23^{\circ} \mathrm{C}$ in September. It declines to $19.85^{\circ} \mathrm{C}$ in October, $19.28^{\circ} \mathrm{C}$ in November, and rose to $19.47^{\circ} \mathrm{C}$ in December.

Figure 50 shows the cumulative cash flows of the current and proposed power systems for Rwanda over the economic lifespan of the power plants. The cash flows at the inception of both the current and proposed power systems were about US\$-116,129.03 and US\$870,967.42, respectively. Both the current and proposed power systems generated US\$1,800,000.00 cash flows each during 8.33 years of their economic lifespan, respectively. At the end of their economic 


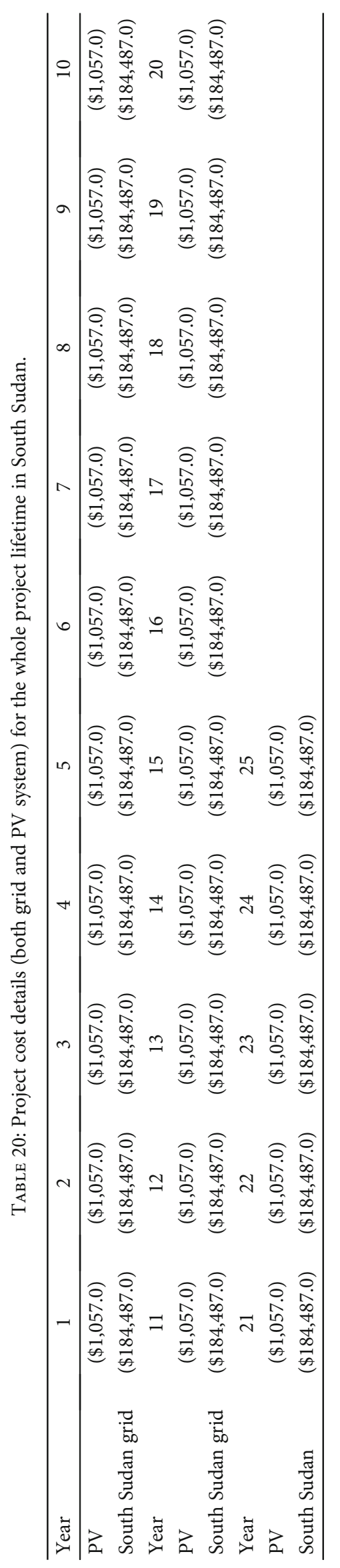


TABLE 21: Utility monthly summary—current system (South Sudan).

\begin{tabular}{|c|c|c|c|c|c|c|c|c|c|c|}
\hline Month & $\begin{array}{c}\text { Energy } \\
\text { purchased } \\
(\mathrm{kWh})\end{array}$ & $\begin{array}{c}\text { Energy sold } \\
\text { (kWh) }\end{array}$ & $\begin{array}{c}\text { Net energy } \\
\text { purchased (kWh) }\end{array}$ & $\begin{array}{l}\text { Peak load } \\
(\mathrm{kW})\end{array}$ & $\begin{array}{l}\text { Energy } \\
\text { charge }\end{array}$ & $\begin{array}{l}\text { Demand } \\
\text { charge }\end{array}$ & $\begin{array}{l}\text { Fixed } \\
\text { charge }\end{array}$ & $\begin{array}{l}\text { Minimum } \\
\text { charge }\end{array}$ & Taxes & Total \\
\hline January & $86,800.0$ & 0.0 & $86,800.0$ & 200.0 & $\$ 37,324.0$ & $\$ 0.0$ & $\$ 0.0$ & $\$ 0.0$ & $\$ 0.0$ & $\$ 37,324.0$ \\
\hline February & $78,400.0$ & 0.0 & $78,400.0$ & 200.0 & $\$ 33,712.0$ & $\$ 0.0$ & $\$ 0.0$ & $\$ 0.0$ & $\$ 0.0$ & $\$ 33,712.0$ \\
\hline March & $86,800.0$ & 0.0 & $86,800.0$ & 200.0 & $\$ 37,324.0$ & $\$ 0.0$ & $\$ 0.0$ & $\$ 0.0$ & $\$ 0.0$ & $\$ 37,324.0$ \\
\hline April & $84,000.0$ & 0.0 & $84,000.0$ & 200.0 & $\$ 36,120.0$ & $\$ 0.0$ & $\$ 0.0$ & $\$ 0.0$ & $\$ 0.0$ & $\$ 36,120.0$ \\
\hline May & $86,800.0$ & 0.0 & $86,800.0$ & 200.0 & $\$ 37,324.0$ & $\$ 0.0$ & $\$ 0.0$ & $\$ 0.0$ & $\$ 0.0$ & $\$ 37,324.0$ \\
\hline June & $84,000.0$ & 0.0 & $84,000.0$ & 200.0 & $\$ 36,120.0$ & $\$ 0.0$ & $\$ 0.0$ & $\$ 0.0$ & $\$ 0.0$ & $\$ 36,120.0$ \\
\hline July & $86,800.0$ & 0.0 & $86,800.0$ & 200.0 & $\$ 37,324.0$ & $\$ 0.0$ & $\$ 0.0$ & $\$ 0.0$ & $\$ 0.0$ & $\$ 37,324.0$ \\
\hline August & $86,800.0$ & 0.0 & $86,800.0$ & 200.0 & $\$ 37,324.0$ & $\$ 0.0$ & $\$ 0.0$ & $\$ 0.0$ & $\$ 0.0$ & $\$ 37,324.0$ \\
\hline September & $84,000.0$ & 0.0 & $84,000.0$ & 200.0 & $\$ 36,120.0$ & $\$ 0.0$ & $\$ 0.0$ & $\$ 0.0$ & $\$ 0.0$ & $\$ 36,120.0$ \\
\hline October & $86,800.0$ & 0.0 & $86,800.0$ & 200.0 & $\$ 37,324.0$ & $\$ 0.0$ & $\$ 0.0$ & $\$ 0.0$ & $\$ 0.0$ & $\$ 37,324.0$ \\
\hline November & $84,000.0$ & 0.0 & $84,000.0$ & 200.0 & $\$ 36,120.0$ & $\$ 0.0$ & $\$ 0.0$ & $\$ 0.0$ & $\$ 0.0$ & $\$ 36,120.0$ \\
\hline December & $86,800.0$ & 0.0 & $86,800.0$ & 200.0 & $\$ 37,324.0$ & $\$ 0.0$ & $\$ 0.0$ & $\$ 0.0$ & $\$ 0.0$ & $\$ 37,324.0$ \\
\hline Annual & $1,022,000.0$ & 0.0 & $1,022,000.0$ & 200.0 & $\$ 439,460.0$ & $\$ 0.0$ & $\$ 0.0$ & $\$ 0.0$ & $\$ 0.0$ & $\$ 439,460.0$ \\
\hline
\end{tabular}

TABLE 22: Utility monthly summary-proposed system (South Sudan).

\begin{tabular}{|c|c|c|c|c|c|c|c|c|c|c|}
\hline Month & $\begin{array}{c}\text { Energy } \\
\text { purchased } \\
(\mathrm{kWh})\end{array}$ & $\begin{array}{l}\text { Energy sold } \\
\text { (kWh) }\end{array}$ & $\begin{array}{c}\text { Net energy } \\
\text { purchased (kWh) }\end{array}$ & $\begin{array}{l}\text { Peak load } \\
\quad(\mathrm{kW})\end{array}$ & $\begin{array}{l}\text { Energy } \\
\text { charge }\end{array}$ & $\begin{array}{l}\text { Demand } \\
\text { charge }\end{array}$ & $\begin{array}{l}\text { Fixed } \\
\text { charge }\end{array}$ & $\begin{array}{l}\text { Minimum } \\
\text { charge }\end{array}$ & Taxes & Total \\
\hline January & $45,684.0$ & $21,567.0$ & $24,117.0$ & 200.0 & $\$ 13,649.0$ & $\$ 0.0$ & $\$ 0.0$ & $\$ 0.0$ & $\$ 0.0$ & $\$ 13,649.0$ \\
\hline February & $40,410.0$ & $19,621.0$ & $20,789.0$ & 200.0 & $\$ 11,922.0$ & $\$ 0.0$ & $\$ 0.0$ & $\$ 0.0$ & $\$ 0.0$ & $\$ 11,922.0$ \\
\hline March & $45,537.0$ & $20,662.0$ & $24,874.0$ & 200.0 & $\$ 13,837.0$ & $\$ 0.0$ & $\$ 0.0$ & $\$ 0.0$ & $\$ 0.0$ & $\$ 13,837.0$ \\
\hline April & $42,784.0$ & $18,699.0$ & $24,085.0$ & 200.0 & $\$ 13,199.0$ & $\$ 0.0$ & $\$ 0.0$ & $\$ 0.0$ & $\$ 0.0$ & $\$ 13,199.0$ \\
\hline May & $47,697.0$ & $13,265.0$ & $34,432.0$ & 200.0 & $\$ 16,822.0$ & $\$ 0.0$ & $\$ 0.0$ & $\$ 0.0$ & $\$ 0.0$ & $\$ 16,822.0$ \\
\hline June & $47,516.0$ & $9,442.0$ & $38,074.0$ & 200.0 & $\$ 17,807.0$ & $\$ 0.0$ & $\$ 0.0$ & $\$ 0.0$ & $\$ 0.0$ & $\$ 17,807.0$ \\
\hline July & $51,307.0$ & $8,827.0$ & $42,480.0$ & 200.0 & $\$ 19,608.0$ & $\$ 0.0$ & $\$ 0.0$ & $\$ 0.0$ & $\$ 0.0$ & $\$ 19,608.0$ \\
\hline August & $50,585.0$ & $11,225.0$ & $39,360.0$ & 200.0 & $\$ 18,631.0$ & $\$ 0.0$ & $\$ 0.0$ & $\$ 0.0$ & $\$ 0.0$ & $\$ 18,631.0$ \\
\hline September & $48,309.0$ & $15,079.0$ & $33,229.0$ & 200.0 & $\$ 16,581.0$ & $\$ 0.0$ & $\$ 0.0$ & $\$ 0.0$ & $\$ 0.0$ & $\$ 16,581.0$ \\
\hline October & $46,807.0$ & $15,384.0$ & $31,423.0$ & 200.0 & $\$ 15,850.0$ & $\$ 0.0$ & $\$ 0.0$ & $\$ 0.0$ & $\$ 0.0$ & $\$ 15,850.0$ \\
\hline November & $43,428.0$ & $20,432.0$ & $22,995.0$ & 200.0 & $\$ 12,994.0$ & $\$ 0.0$ & $\$ 0.0$ & $\$ 0.0$ & $\$ 0.0$ & $\$ 12,994.0$ \\
\hline December & $45,037.0$ & $20,781.0$ & $24,255.0$ & 200.0 & $\$ 13,589.0$ & $\$ 0.0$ & $\$ 0.0$ & $\$ 0.0$ & $\$ 0.0$ & $\$ 13,589.0$ \\
\hline Annual & $555,099.0$ & $194,985.0$ & $360,114.0$ & 200.0 & $\$ 184,487.0$ & $\$ 0.0$ & $\$ 0.0$ & $\$ 0.0$ & $\$ 0.0$ & $\$ 184,487.0$ \\
\hline
\end{tabular}

TABLE 23: Solar PV minigrids in Rwanda.

\begin{tabular}{lcc}
\hline Minigrid & Capacity & Sites \\
\hline RENERG & $30.0 \mathrm{~kW}$ & 1 \\
Neseltec & $30.0 \mathrm{~kW}$ & 1 \\
Meshpower & $1.0 \mathrm{~kW}$ & 69 \\
\hline
\end{tabular}

life, the cash flows for both the current and proposed power systems were US $\$ 3,367,741.94$ and US $\$ 2,525,806.45$. Taking the areas under each cash flow curve, the total cumulative cash flows for both the current and proposed power systems were US $\$ 42,096,774.20$ and US $\$ 42,459,673.40$, respectively. The gross cumulative cash flows of the proposed power system were US $\$ 362,899.12$ greater than those of the current grid system. That means the proposed power is preferable to the current power system in Rwanda.

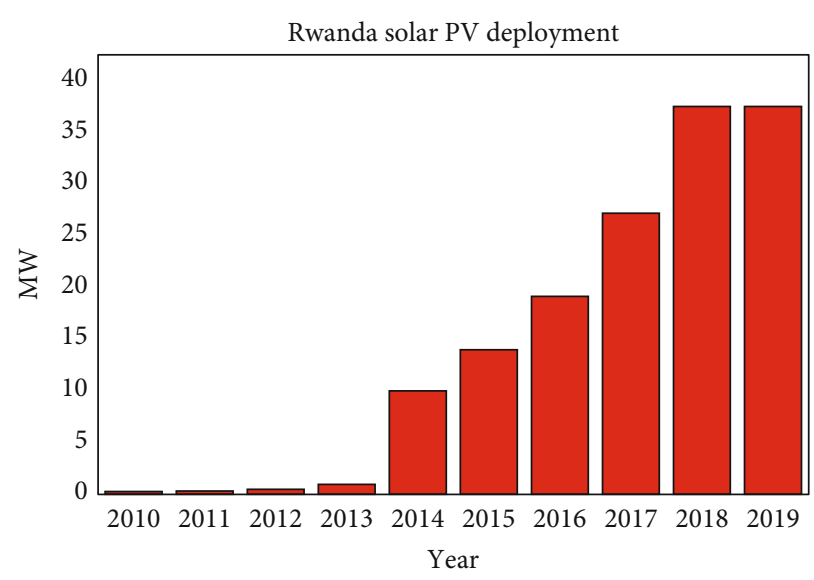

MW

FIgURE 46: Solar PV trends in Rwanda by IRENA. 
TABLE 24: Institutions involved in the energy sector in Rwanda.

\begin{tabular}{lcc}
\hline Institution & \multicolumn{1}{c}{ Mandate } & Ref \\
\hline $\begin{array}{l}\text { Rwanda Energy } \\
\text { Group }\end{array}$ & $\begin{array}{c}\text { National electric utility overseeing } \\
\text { generation, transmission, and } \\
\text { supply of electricity to consumers. } \\
\text { Responsible for the construction } \\
\text { of national generation, }\end{array}$ & \\
$\begin{array}{l}\text { Ministry of } \\
\text { Infrastructure } \\
\text { (MINIFRA) }\end{array}$ & $\begin{array}{c}\text { transmission, and distribution } \\
\text { infrastructure. Rural energy is part } \\
\text { of this portfolio. }\end{array}$ & {$[68]$} \\
$\begin{array}{l}\text { Rwanda's Utility } \\
\text { Regulation Authority } \\
\text { (RURA) }\end{array}$ & $\begin{array}{l}\text { (i) Ensures set tools of regulation } \\
\text { are in place and enforces them. }\end{array}$ & [66, \\
\hline
\end{tabular}

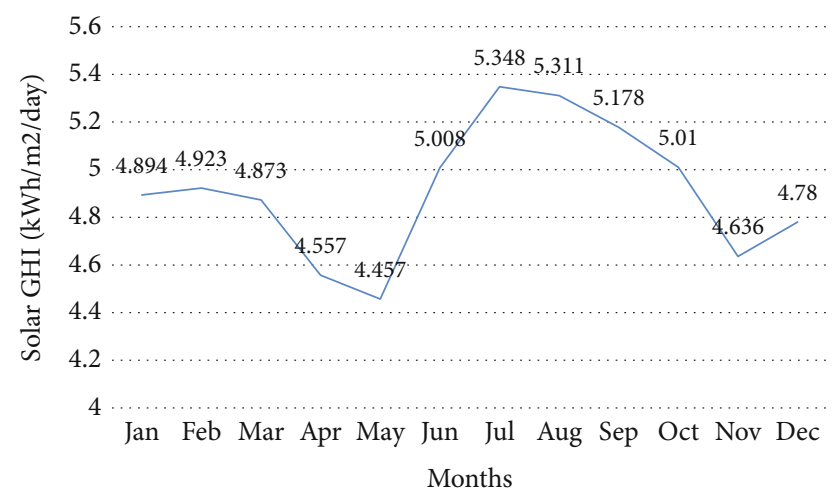

Figure 47: Monthly solar Global Horizontal Irradiation (GHI $\mathrm{kWh} / \mathrm{m}^{2} /$ day) for Rwanda.

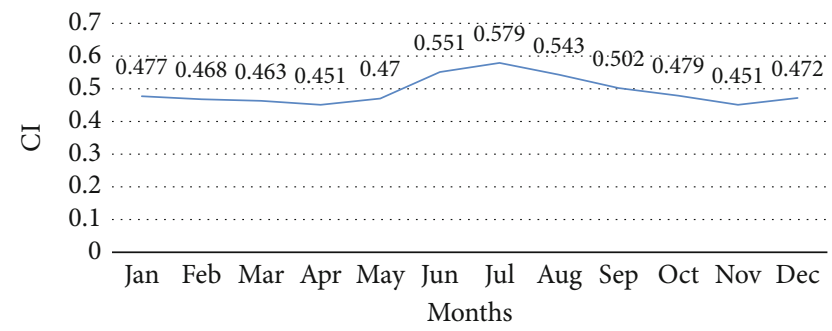

FIGURE 48: Monthly clearness index (CI) for Rwanda.

Figure 51 depicts the categorized annual savings for the proposed power system for Rwanda. The annual energy was about US $\$ 134,816.00$, US $\$ 1,057.00$ the operations and maintenance, while the annual energy cost savings were US $\$ 133,760.00$, respectively.

Figure 52 shows the monthly utility bills for the current and proposed power systems for Rwanda. The January bills for both the current and proposed power systems were US $\$ 22,518.26$ and US $\$ 11,259.26$, respectively. The February bills for both the current and proposed power systems were US\$20,296.30 and US\$10,074.07, respectively. The March bills for both the current and proposed power systems were US $\$ 22,518.52$ and US\$11,259.26, respectively. The April bills for both the current and proposed power systems were US $\$ 21,777.78$ and US\$11,259.26, respectively. The May bills

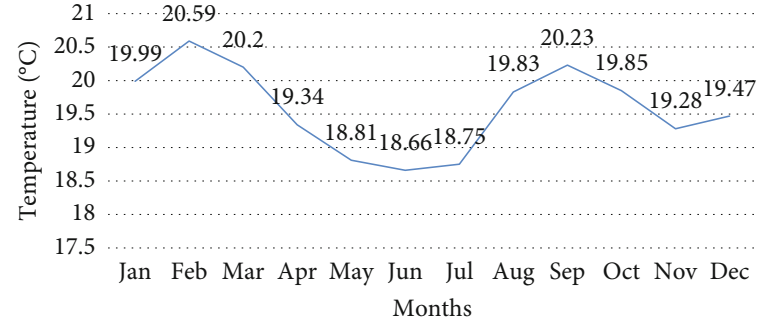

Figure 49: Monthly temperature variation $\left({ }^{\circ} \mathrm{C}\right)$ for Rwanda.

for both the current and proposed power systems were US $\$ 22,518.52$ and US\$11,851.85, respectively. The June bills for both the current and proposed power systems were US $\$ 21,777.78$ and US $\$ 10,222.22$, respectively. The July bills for both the current and proposed power systems were US\$22,518.52 and US\$9,777.78, respectively. The August bills for both the current and proposed power systems were US\$22,518.52 and US\$10,074.07, respectively. The September bills for both the current and proposed power systems were US\$21,777.78 and US\$10,370.37, respectively. The October bills for both the current and proposed power systems were US\$22,518.52 and US\$10,814.82, respectively. The November bills for both the current and proposed power systems were US $\$ 21,777.78$ and US $\$ 11,555.56$, respectively. The December bills for both the current and proposed power systems were US\$22,518.52 and US\$11,555.56, respectively.

Table 25 depicts the annual utility bills and savings by category for Rwanda. The base case consumption charge was US\$264,698.00, US\$129,882.00 the proposed power system consumption charge, and US\$134,816.00 the annual savings.

Figure 53 reflects the electrical production capacities for both the utility grid and the proposed solar PV microgrid power technology in Rwanda. The January electrical production capacities for both the current grid and proposed solar PV microgrid were 101.16 MWh and 47.60 MWh, respectively. The February electrical production capacities for both the current grid and proposed solar PV microgrid were 89.26 MWh and 43.64 MWh, respectively. The March electrical production capacities for both the current grid and proposed solar PV microgrid were $100.00 \mathrm{MWh}$ and 48.00 MWh, respectively. The April electrical production capacities for both the current grid and proposed solar PV microgrid were $94.00 \mathrm{MWh}$ and $44.00 \mathrm{MWh}$, respectively. The May electrical production capacities for both the current grid and proposed solar PV microgrid were 97.00 MWh and 44.60 MWh, respectively. The June electrical production capacities for both the current grid and proposed solar PV microgrid were 96.00 MWh and 49.00 MWh, respectively. The July electrical production capacities for both the current grid and proposed solar PV microgrid were 100.00 MWh and 54.00 MWh, respectively. The August electrical production capacities for both the current grid and proposed solar PV microgrid were $102.00 \mathrm{MWh}$ and $54.00 \mathrm{MWh}$, respectively. The September electrical production capacities for both the current grid and proposed solar PV microgrid were 99.00 MWh and 50.00 MWh, respectively. The October 


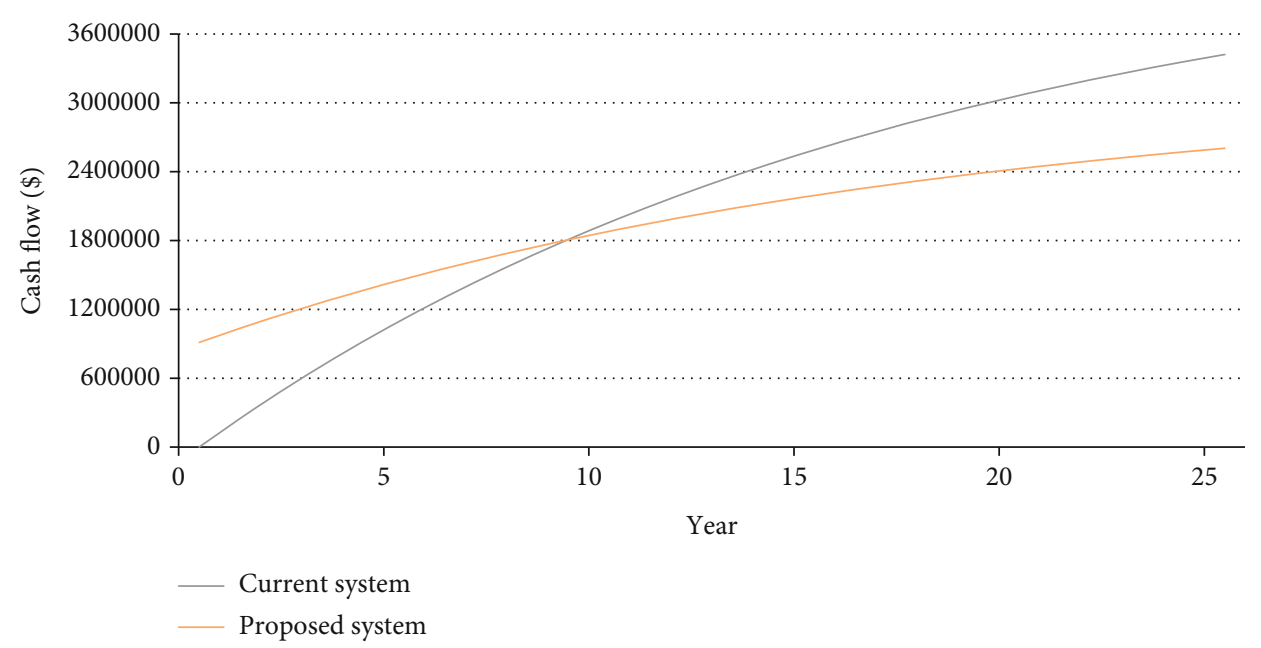

FigurE 50: Cumulative cash flows over project lifetime for the current and proposed systems for Rwanda.

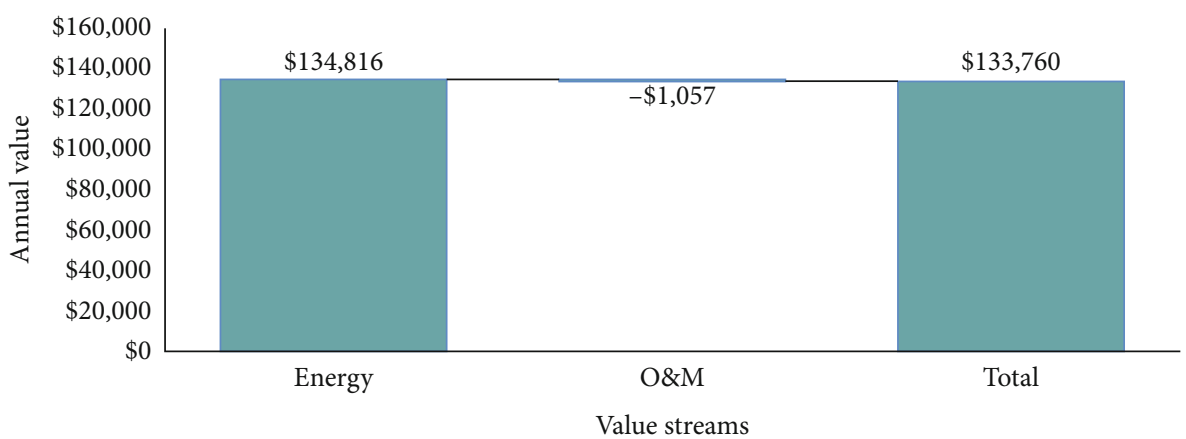

FIGURE 51: Categorized annual savings for the proposed system for Rwanda.

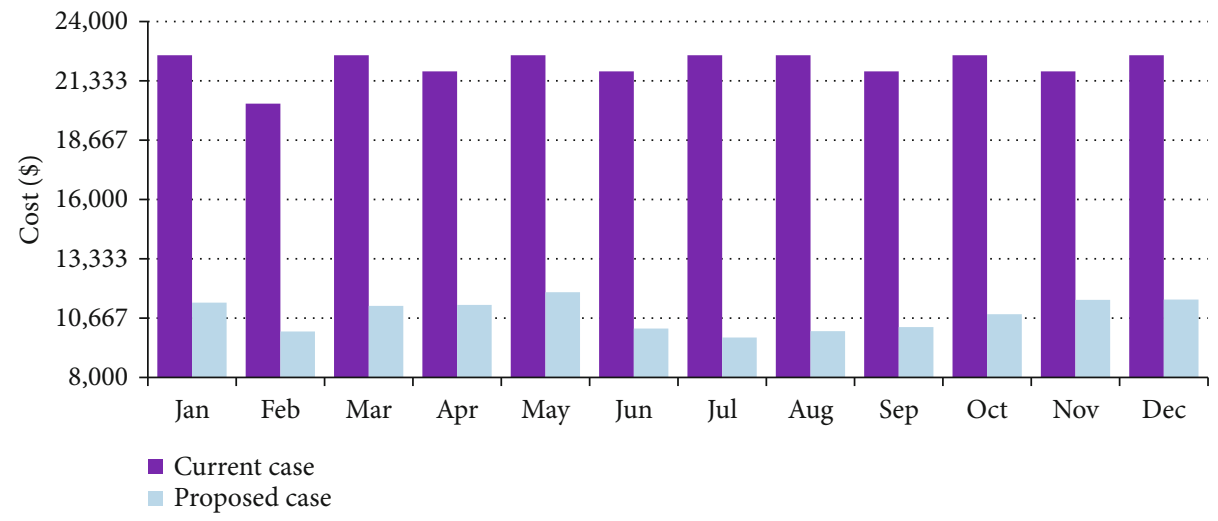

Figure 52: Monthly utility bills for the current and proposed systems for Rwanda.

TABLE 25: Annual utility bills and savings by category (Rwanda).

\begin{tabular}{lcc}
\hline & Consumption charge & Total \\
\hline Base case & $\$ 264,698.0$ & $\$ 264,698.0$ \\
Proposed case & $\$ 129,882.0$ & $\$ 129,882.0$ \\
Annual savings & $\$ 134,816.0$ & $\$ 134,816.0$ \\
\hline
\end{tabular}

Note: the base case is considered as the current system (grid connection) and the proposed power system is the grid-connected solar PV microgrid with storage. electrical production capacities for both the current grid and proposed solar PV microgrid were $99.00 \mathrm{MWh}$ and $50.00 \mathrm{MWh}$, respectively. The November electrical production capacities for both the current grid and proposed solar PV microgrid were 96.00 MWh and 44.00 MWh, respectively. The December electrical production capacities for both the current grid and proposed solar PV microgrid were 99.00 MWh and 47.00 MWh, respectively.

Additionally, the solar PV system has a nominal capacity of $400.0 \mathrm{~kW}$, and its annual production is 


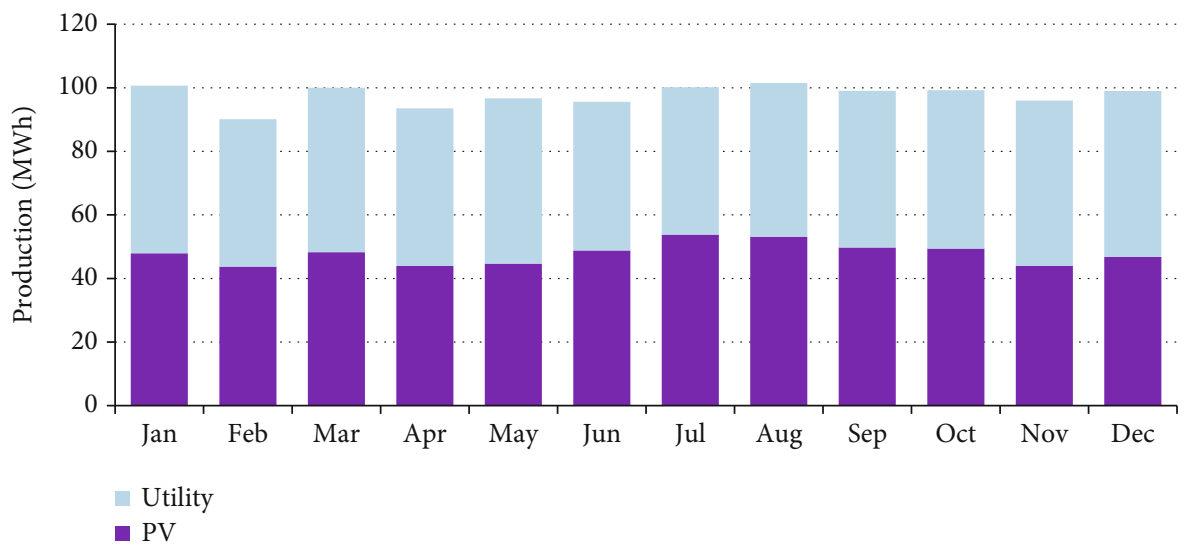

Figure 53: The electrical production for both utility and the solar PV microgrid for the proposed technology in Rwanda.

$574217.0 \mathrm{kWh} /$ year, and a specific yield of $1436.0 \mathrm{kWh} / \mathrm{kW}$. Table 26 depicts the project cost details for every year over the 25 years project lifespan for Rwanda. The proposed solar PV power generation costs US $\$ 1,057.00$ per annum while the current grid power system costs US $\$ 129,882.00$ every year.

Table 27 is the monthly utility summary for the current grid power system in Rwanda. The energy purchase for January, March, May, July, August, October, and December was each $86,400.0 \mathrm{kWh}$, respectively. Although the 78,400.0 kWh was the energy purchase for February, 84,000.0 kWh was each of the energy purchases for April, June, September, and November, respectively. The annual energy purchase was $1,022,000.0 \mathrm{kWh}$, and the peak load was $200.0 \mathrm{~kW}$ throughout the year. There was no energy sold, and the annual energy charge was US\$264,698.00. Also, each demand charge, fixed charge, minimum charge, and taxes were all zero, respectively.

Table 28 indicates the utility monthly summary for the proposed power system in Rwanda. The energy purchase for every month of the year was variable, and the total annual energy purchase was $597,309 \mathrm{kWh}$. While the energy sold also varied from one month to another, the annual energy sold was $149,526.0 \mathrm{kWh}$, and the annual net energy purchase was $444,783.0 \mathrm{kWh}$. The peak load was $200.0 \mathrm{kWp}$, and the annual energy charge was US\$129,882.0. Also, the demand charge, fixed charge, minimum charge, and taxes were zero, respectively.

4.2. Overview of the Region. Hybrid renewable energy minigrid investment costs greatly fluctuate per $\mathrm{kWp}$, depending on several key factors [27]. The diversity in investment costs and tariffs is due to several economic realities within the countries. Government subsidies, location of minigrids, competing for alternative energy sources, and purchasing power are among the factors that affect the cost of investment and cost of power. While a blended tariff structure is more realistic for most minigrid investments, the East Africa region mostly employs fixed tariffs. Kenya is leading with some of the highest investment costs per $\mathrm{kWp}$ ranging from US\$ $5,100.0$ to US\$ $13,575.0$ which translates into the most expensive tariffs for off-grid power. Uganda has the highest tariff at US\$0.21 for grid-connected customers. Table 29 indicates minigrid investment costs in Uganda.

According to the IRENA, $245.5 \mathrm{MW}$ of power is collectively being generated using the solar PV technology either by grids or stand-alone systems in the six East Africa countries. Kenya is currently treading its last-mile towards achieving complete electricity access initially intended for 2030. It is also considered exemplary in Sub-Saharan Africa in terms of electrification strategies [71]. Kenya is leading in installations and has the highest electrification rates at $84.5 \%$ in the region. However, 13 million people, the third-largest population in the region, are yet to be provided with electricity. High-profile government initiatives like the last-mile connectivity project, several PPP solar PV projects, international support, and successful innovations like the pay-as-you-go platform have yielded pronounced growth in electrification. Moreover, previous diesel minigrids are being transformed into diesel-solar minigrids, and the hybrid is also being replicated in rural areas [71].

Tanzania has the largest population without electricity at 36 million despite having a robust and established framework for minigrid regulation using the small power producer policy. It is third in the region with installations totaling $25.56 \mathrm{MW}$ which is an estimated $0.02 \%$ of the total country's capacity. The quantity increases to $0.05 \%$ with the inclusion of solar hybrid systems. Tanzania's electrification rate is at $39.5 \%$, which could benefit more from solar electrification as it has a grid-tied solar PV potential of $800 \mathrm{MW}$ which can cover approximately $20 \%$ of peak demand during daytime [48].

The policy framework in Rwanda is fairly developed, using their 2018 electrification strategy the country is working to provide electricity to its entire rural and urban population within six years unfolding the most ambitious plan in the region. The country has the second-highest electrification rates at $52.6 \%$. Since 2007 , a combination of utility reforms, voluntary suggestions, tenders, donor support, and favorable tax regimes has attracted private investors to Rwanda producing a total of 47 PPAs being signed by the year 2019. All IPPs currently participate through a competitive tendering process supervised by the Rwanda Utility Regulatory Authority (RURA) [49]. 


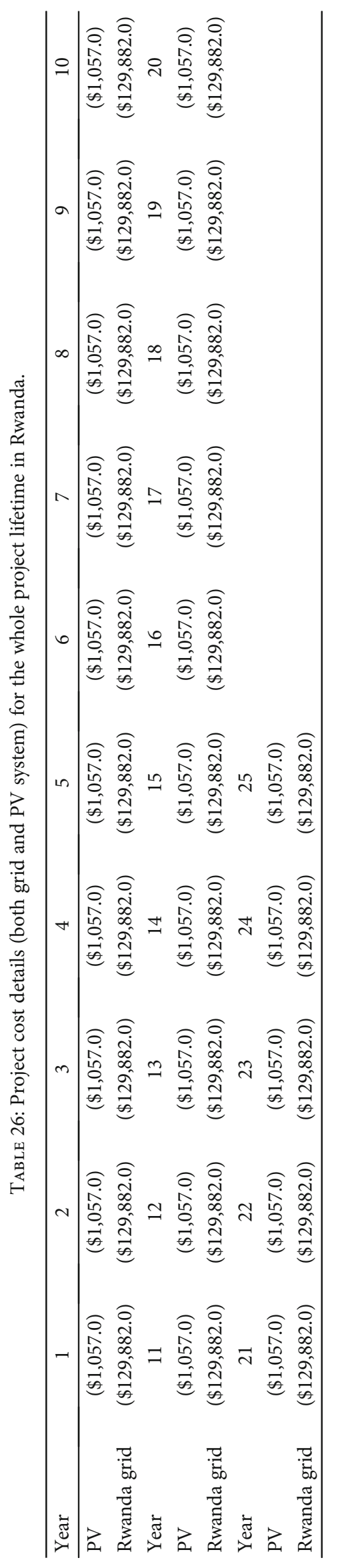


TABLE 27: Utility monthly summary-current system (Rwanda).

\begin{tabular}{|c|c|c|c|c|c|c|c|c|c|c|}
\hline Month & $\begin{array}{c}\text { Energy } \\
\text { purchased } \\
(\mathrm{kWh})\end{array}$ & $\begin{array}{l}\text { Energy sold } \\
\quad(\mathrm{kWh})\end{array}$ & $\begin{array}{c}\text { Net energy } \\
\text { purchased (kWh) }\end{array}$ & $\begin{array}{l}\text { Peak load } \\
(\mathrm{kW})\end{array}$ & $\begin{array}{l}\text { Energy } \\
\text { charge }\end{array}$ & $\begin{array}{l}\text { Demand } \\
\text { charge }\end{array}$ & $\begin{array}{l}\text { Fixed } \\
\text { charge }\end{array}$ & $\begin{array}{l}\text { Minimum } \\
\text { charge }\end{array}$ & Taxes & Total \\
\hline January & $86,800.0$ & 0.0 & $86,800.0$ & 200.0 & $\$ 22,481.0$ & $\$ 0.0$ & $\$ 0.0$ & $\$ 0.0$ & $\$ 0.0$ & $\$ 22,481.0$ \\
\hline February & $78,400.0$ & 0.0 & $78,400.0$ & 200.0 & $\$ 20,306.0$ & $\$ 0.0$ & $\$ 0.0$ & $\$ 0.0$ & $\$ 0.0$ & $\$ 20,306.0$ \\
\hline March & $86,800.0$ & 0.0 & $86,800.0$ & 200.0 & $\$ 22,481.0$ & $\$ 0.0$ & $\$ 0.0$ & $\$ 0.0$ & $\$ 0.0$ & $\$ 22,481.0$ \\
\hline April & $84,000.0$ & 0.0 & $84,000.0$ & 200.0 & $\$ 21,756.0$ & $\$ 0.0$ & $\$ 0.0$ & $\$ 0.0$ & $\$ 0.0$ & $\$ 21,756.0$ \\
\hline May & $86,800.0$ & 0.0 & $86,800.0$ & 200.0 & $\$ 22,481.0$ & $\$ 0.0$ & $\$ 0.0$ & $\$ 0.0$ & $\$ 0.0$ & $\$ 22,481.0$ \\
\hline June & $84,000.0$ & 0.0 & $84,000.0$ & 200.0 & $\$ 21,756.0$ & $\$ 0.0$ & $\$ 0.0$ & $\$ 0.0$ & $\$ 0.0$ & $\$ 21,756.0$ \\
\hline July & $86,800.0$ & 0.0 & $86,800.0$ & 200.0 & $\$ 22,481.0$ & $\$ 0.0$ & $\$ 0.0$ & $\$ 0.0$ & $\$ 0.0$ & $\$ 22,481.0$ \\
\hline August & $86,800.0$ & 0.0 & $86,800.0$ & 200.0 & $\$ 22,481.0$ & $\$ 0.0$ & $\$ 0.0$ & $\$ 0.0$ & $\$ 0.0$ & $\$ 22,481.0$ \\
\hline September & $84,000.0$ & 0.0 & $84,000.0$ & 200.0 & $\$ 21,756.0$ & $\$ 0.0$ & $\$ 0.0$ & $\$ 0.0$ & $\$ 0.0$ & $\$ 21,756.0$ \\
\hline October & $86,800.0$ & 0.0 & $86,800.0$ & 200.0 & $\$ 22,481.0$ & $\$ 0.0$ & $\$ 0.0$ & $\$ 0.0$ & $\$ 0.0$ & $\$ 22,481.0$ \\
\hline November & $84,000.0$ & 0.0 & $84,000.0$ & 200.0 & $\$ 21,756.0$ & $\$ 0.0$ & $\$ 0.0$ & $\$ 0.0$ & $\$ 0.0$ & $\$ 21,756.0$ \\
\hline December & $86,800.0$ & 0.0 & $86,800.0$ & 200.0 & $\$ 22,481.0$ & $\$ 0.0$ & $\$ 0.0$ & $\$ 0.0$ & $\$ 0.0$ & $\$ 22,481.0$ \\
\hline Annual & $1,022,000.0$ & 0.0 & $1,022,000.0$ & 200.0 & $\$ 264,698.0$ & $\$ 0.0$ & $\$ 0.0$ & $\$ 0.0$ & $\$ 0.0$ & $\$ 264,698.0$ \\
\hline
\end{tabular}

TABLE 28: Utility monthly summary-proposed system (Rwanda).

\begin{tabular}{|c|c|c|c|c|c|c|c|c|c|c|}
\hline Month & $\begin{array}{c}\text { Energy } \\
\text { purchased } \\
(\mathrm{kWh})\end{array}$ & $\begin{array}{l}\text { Energy sold } \\
\text { (kWh) }\end{array}$ & $\begin{array}{c}\text { Net energy } \\
\text { purchased }(\mathrm{kWh})\end{array}$ & $\begin{array}{l}\text { Peak load } \\
\quad(\mathrm{kW})\end{array}$ & $\begin{array}{l}\text { Energy } \\
\text { charge }\end{array}$ & $\begin{array}{l}\text { Demand } \\
\text { charge }\end{array}$ & $\begin{array}{l}\text { Fixed } \\
\text { charge }\end{array}$ & $\begin{array}{l}\text { Minimum } \\
\text { charge }\end{array}$ & Taxes & Total \\
\hline January & $52,735.0$ & $13,851.0$ & $38,884.0$ & 200.0 & $\$ 11,359.0$ & $\$ 0.0$ & $\$ 0.0$ & $\$ 0.0$ & $\$ 0.0$ & $\$ 11,359.0$ \\
\hline February & $46,366.0$ & $11,719.0$ & $34,646.0$ & 200.0 & $\$ 10,063.0$ & $\$ 0.0$ & $\$ 0.0$ & $\$ 0.0$ & $\$ 0.0$ & $\$ 10,063.0$ \\
\hline March & $51,789.0$ & $13,245.0$ & $38,544.0$ & 200.0 & $\$ 11,215.0$ & $\$ 0.0$ & $\$ 0.0$ & $\$ 0.0$ & $\$ 0.0$ & $\$ 11,215.0$ \\
\hline April & $49,548.0$ & $9,497.0$ & $40,051.0$ & 200.0 & $\$ 11,256.0$ & $\$ 0.0$ & $\$ 0.0$ & $\$ 0.0$ & $\$ 0.0$ & $\$ 11,256.0$ \\
\hline May & $52,010.0$ & $9,883.0$ & $42,128.0$ & 200.0 & $\$ 11,830.0$ & $\$ 0.0$ & $\$ 0.0$ & $\$ 0.0$ & $\$ 0.0$ & $\$ 11,830.0$ \\
\hline June & $46,791.0$ & $11,587.0$ & $35,204.0$ & 200.0 & $\$ 10,195.0$ & $\$ 0.0$ & $\$ 0.0$ & $\$ 0.0$ & $\$ 0.0$ & $\$ 10,195.0$ \\
\hline July & $46,363.0$ & $13,353.0$ & $33,010.0$ & 200.0 & $\$ 9,791.0$ & $\$ 0.0$ & $\$ 0.0$ & $\$ 0.0$ & $\$ 0.0$ & $\$ 9,791.0$ \\
\hline August & $48,355.0$ & $14,699.0$ & $33,657.0$ & 200.0 & $\$ 10,084.0$ & $\$ 0.0$ & $\$ 0.0$ & $\$ 0.0$ & $\$ 0.0$ & $\$ 10,084.0$ \\
\hline September & $49,253.0$ & $15,026.0$ & $34,227.0$ & 200.0 & $\$ 10,262.0$ & $\$ 0.0$ & $\$ 0.0$ & $\$ 0.0$ & $\$ 0.0$ & $\$ 10,262.0$ \\
\hline October & $49,836.0$ & $12,459.0$ & $37,377.0$ & 200.0 & $\$ 10,839.0$ & $\$ 0.0$ & $\$ 0.0$ & $\$ 0.0$ & $\$ 0.0$ & $\$ 10,839.0$ \\
\hline November & $52,030.0$ & $11,997.0$ & $40,033.0$ & 200.0 & $\$ 11,484.0$ & $\$ 0.0$ & $\$ 0.0$ & $\$ 0.0$ & $\$ 0.0$ & $\$ 11,484.0$ \\
\hline December & $52,232.0$ & $12,210.0$ & $40,022.0$ & 200.0 & $\$ 11,501.0$ & $\$ 0.0$ & $\$ 0.0$ & $\$ 0.0$ & $\$ 0.0$ & $\$ 11,501.0$ \\
\hline Annual & $597,309.0$ & $149,526.0$ & $447,783.0$ & 200.0 & $\$ 129,882.0$ & $\$ 0.0$ & $\$ 0.0$ & $\$ 0.0$ & $\$ 0.0$ & $\$ 129,882.0$ \\
\hline
\end{tabular}

TABLE 29: Minigrid investment costs.

\begin{tabular}{lcccc}
\hline Country & $\begin{array}{c}\text { Cost per } \\
\text { kWp in } \\
\text { US\$ }\end{array}$ & $\begin{array}{c}\text { Off-grid minigrid } \\
\text { Tariff is US\$/kWh }\end{array}$ & $\begin{array}{c}\text { Grid-connected } \\
\text { Tariff US\$/kWh }\end{array}$ & Ref \\
\hline Kenya & $\begin{array}{c}5,100.0- \\
13,575.0\end{array}$ & $0.67-0.80$ & 0.20 & {$[27]$} \\
Uganda & - & $0.30-0.50$ & $0.085-0.21$ & {$[11$,} \\
Tanzania & - & $0.30-0.65$ & 0.20 & {$[70]$} \\
Rwanda & $4,000.0-$ & $0.35-0.70$ & & {$[59$,} \\
Burundi & $7,000.0$ & & & $65]$ \\
South & $2,200.0$ & & & \\
Sudan & - & $0.41-1.00$ & & \\
\hline
\end{tabular}

Notes: the use of the hyphen (-) does not mean a lack of cost but rather the information was unavailable.
Uganda has a policy with the aim of developing gridcompliant distribution infrastructure for minigrid projects, which effect has a value of approximately $30.0 \%$ of the total project cost. This feature while showing the robustness of the government's support, it has a risk of dragging the technology uptake if the government does not have the finances. It also has a measure of over complexity and inefficiency in some projects making it counterproductive. The country's electrification rate is at $28.9 \%$ with a population of 25 million people without access to electricity. While the minigrids are considered an opportunity for rural electrification, the country remains focused on grid extension. As of 2018, there were no PPA-eligible minigrids in Uganda [19].

Currently, Burundi and South Sudan are the lowest on electrification rates at $10.9 \%$ and $1.1 \%$ in that order. Solar PV minigrids are essentially donor-funded and are being 
TABle 30: Minigrid operation models in East Africa.

\begin{tabular}{|c|c|c|}
\hline Model type & Description & Ref. \\
\hline $\begin{array}{l}\text { Independent Power } \\
\text { Producer (IPP) }\end{array}$ & $\begin{array}{l}\text { Minigrids manage the generation and sale of power to a national utility, the } \\
\text { payment is made under a PPA. These minigrids are constructed using a } \\
\text { PPP whereby he Government provides the land, electricity distribution assets, } \\
\text { and other support structures through rural electrification authorities. }\end{array}$ & {$[29]$} \\
\hline $\begin{array}{l}\text { Distribution } \\
\text { concession }\end{array}$ & $\begin{array}{l}\text { This model gives allows the minigrid operators to do electricity distribution and } \\
\text { supply. However, the minigrid can do generation or buy the electricity from } \\
\text { elsewhere, i.e., from the national grid and retail to end-users. This arrangement } \\
\text { has a definite period and specific location. The private company is therefore } \\
\text { responsible for the distribution, supply, and revenue collection. However, in some } \\
\text { cases, they also choose to do generation and transmission. }\end{array}$ & {$[25]$} \\
\hline $\begin{array}{l}\text { Electricity } \\
\text { supply }\end{array}$ & $\begin{array}{c}\text { The minigrid operator is in charge of distribution, supply, and revenue collection } \\
\text { of power within a } 50.0 \mathrm{~kW} \text { capacity. These minigrids are usually movable and } \\
\text { therefore can be relocated. }\end{array}$ & {$[31,67,72]$} \\
\hline $\begin{array}{l}\text { Multirevenue } \\
\text { stream }\end{array}$ & $\begin{array}{l}\text { This is based on the creation of power utilization density by supporting additional } \\
\text { services that increase power consumption and increase revenues. }\end{array}$ & Field interview \\
\hline Public model & $\begin{array}{c}\text { Using this model, a national institution constructs and manages the generation, } \\
\text { transmission, and distribution assets. Other national institutions, i.e., the national } \\
\text { utility operates and maintains the assets while another institution develops regulation } \\
\text { tools like tariffs and approves them. }\end{array}$ & {$[30]$} \\
\hline
\end{tabular}

Notes: PPP stands for public-private partnership. PPA stands for the power purchase agreement.

developed for demonstrational reasons and capacity building. Burundi is using the decentralized rural electrification strategy as a blueprint for electrification, although not comprehensive enough to attract significant investments for minigrid development. The strategy does not include specific objectives and does not have supportive policies to guide achievements. South Sudan is also yet to develop an inclusive electrification strategy. The two countries also struggle with old and frail transmission and distribution infrastructure, while in the case of South Sudan, there is no significant infrastructural backbone for either transmission or distribution. South Sudan's efforts are also undermined by the ramifications of a protracted period of civil war in the recent past. Therefore, it is at preparatory phases of generation, transmission, and distribution infrastructure as well as policy development. Overall, the region had a population of 100 million without access to electricity as of the end of 2019. This shows immense opportunity for solar PV minigrid deployment.

4.3. East African Minigrid Models. The operation models are currently not well defined yet in the African continent. Many models are at play but still, none has shown pronounced success. Models can be based on ownership, power output size, or even customer target. Some of the established owneroperator models include public utility, community or nongovernmental organization (NGO), private, and hybrid such as a public-private partnership (PPP). The PPP has become outstanding in its potential for scale-up and currently has the most projects either planned [30] or in the development phase in the six East African Nations. Table 30 indicates minigrid operation models in East Africa.

4.4. Payment Methods. Solar PV energy in East Africa is evolving rapidly due to its ability to serve an assortment of consumers [73]. Minigrids are currently employing customized systems to monitor, control power supply, and collect revenues. Simple as well as sophisticated smart technologies are already being deployed to the convenience of minigrid operators. Smart technologies with features like remote monitoring, cloud control, and mobile payment functions [74]. The Pay-As-You-Go (PAYGO) model that originated in Kenya is being utilized by several companies in the East Africa region [75]. It solves the challenges of exchanging monies, collecting payments from remote customers, who often have irregular cash flow [76] with the inability to do one-off payments, therefore, employing piecemeal payments. Alternatively, public minigrids deploy prepayment meters, especially for grid connections. With the prevalence of cellular networks, mobile money transfer platforms like M-Pesa are popular in the region. Cloud-based remote systems have also been deployed for both metering and as payment platforms for some minigrid operators which monitor energy use and receive revenues due through mobile transfer. Postpaid metering is also employed by some utilities; this is common for public minigrids. As observed in Rwanda, newer minigrids are increasingly adopting smart technologies for operation, among the minigrids which were operational in Rwanda in early 2016, and none was known to make use of smart technologies in monitoring, control, or payment [77] while Kenya has been utilizing smart technologies through mobile platforms since 2009 .

\subsection{Barriers to the Minigrid Uptake and Opportunities}

4.5.1. Policy and Regulations. The policy and regulations for minigrids are quite nomadic as governments are always incorporating new measures from the lessons gained internationally and locally. In East Africa, the policy and regulatory 
framework are largely at experimental phases, in some countries, it is very unspecific or lacking in some countries like South Sudan and Burundi. While the other four countries have policies originally developed for traditional minigrids (generally run by IPPs, communities, and national utilities), third-generation minigrids are steadily increasing and therefore a need for the development of comprehensive policies and regulations covering tariffs, electrification plans, permits, and licenses among other relevant details.

4.5.2. Legal and Licensing Provisions. Securing the required permits and licenses can be a protracted, uncertain and costly process, at times exceeding $10.0 \%$ of the capital cost of a minigrid [78]. Clarity on regulatory requirements is necessary to ease entry into the minigrid market. Simplified and efficient regulatory requirements can significantly lessen development costs. Information on regulatory requirements should be easily accessible and in a single-window if possible (e.g., Tanzania's online information portal, minigrids.go.tz). Although all East African countries have some form of regulatory requirements to be fulfilled, the processes are not well streamlined with investors often being required to visit several organizations that mostly give contradictory or overlapping services. These loopholes create room for ambiguity in services to be offered and sometimes corruption.

4.5.3. Investment and Cost Recovery. Tariff as a tool has a critical impact on the viability and longevity of minigrids. Tariffs are set by the minigrid developers and approved by a relevant body or they could be set by an approved body. Tariffs affect project cash flows, operation, maintenance, and investment cost recovery. Prospects of cost recovery are diverse while private operators strive to recover full capital, operational, management, maintenance costs, and a commensurate margin of profitability, grant-financed minigrids do not need to cover fundamental capital costs. Some minigrids that are managed under the public-private partnership may not need to cover infrastructural costs like is the case of many planned and operational minigrids in Kenya and Uganda, respectively. A custom approach to tariff development is critical for catalyzing the growth of the minigrid sector. In Tanzania, developers of small-scale systems of up to $100.0 \mathrm{~kW}$ are allowed by the government to set tariffs in consultation with the communities being served and therefore exempted from tariff approvals. This allows project developers to try different tariff structures in a flexible regulatory space. However, the tariff structure in most East African countries is not as comprehensive as it should be to cover all the factors that are faced by minigrids operating in remote areas. The tariff structure is mostly based on the scale of power output and the type of energy resource supplying the minigrid. Several other critical parameters like the purchasing power of the locals, the cost of the investment, and the risk associated with the location are not fully covered.

4.5.4. Arrival of the Main Grid. The arrival of the central grid is a possibility that is ever-present. This can draw off power clients and strain the revenue flows. The risk is higher in the years before the full amortization of the investment. In
East Africa, there is an absence of grid-extension plans in countries like South Sudan and Burundi. While the rest of the countries have some plans or drafts yet to be approved, the plans do not address the risk paused exhaustively, sometimes the plans are not adhered to or they are revised frequently. This makes it challenging to project the risk in the planning and development phase of minigrids which heightens the risk even further. In the event of the minigrid arrival, due to a lacking regulatory framework, the government may impound minigrid assets with insignificant reparation, or in the worst case, the investments can be left without recourse.

4.5.5. Facilitation and Access to Finance. Accessing affordable financing is not easy; it is one of the major barriers to the development of minigrids. An assortment of financing mechanisms and creative operation models are necessary for increasing investments. Nearly all minigrids are financed through a mix of finances from subsidies and donations, commercial equity, and rarely loans [79]. Although most minigrids get funding from grants, this kind of funding has high transaction costs and experience significant delays in disbursement, which in turn strain cash flow for developers, most of whom require equity investment to build pilot projects and establish their operation models. Many commercial investors and potential funding partners are discouraged by the lack of a proven, successful model in the sector and the disproportionate returns commonly experienced. Currently, Uganda, Kenya, Rwanda, and Tanzania governments are offering support through conducting feasibility studies for identifying potential minigrid sites. Uganda has a policy with a supportive feature of developing grid-compliant distribution infrastructure for minigrid projects, which effect has a value of approximately $30.0 \%$ of the total project cost. Most of the monies being used for these services are sourced from international donors and development financial institutions. South Sudan has no functional transmission grid, Burundi has an old grid that needs to be upgraded, and these auxiliary assets need substantial financing for development as they are critical in minigrid development.

\section{Concluding Remarks}

The solar PV minigrid uptake in East Africa is still in the formative stages. The most advanced countries have laid down electrification blueprints apportioning the intended use of available natural energy resources and developed supportive measures on how to achieve the plans. Government support in terms of policy and initiatives in Kenya, Rwanda, and Tanzania has been critical in attracting significant funding for rural electrification as well as private investments. For further growth, adherence to policy and regulation, clearing ambiguities in regulations, and adoption of blended tariffs will ease market entry and secure more gains for the sector. In Uganda, while the government is willing to support minigrid deployment, it also has strong indicators focusing on central grid extension. This is a major hurdle for the growth of minigrids. Burundi and South Sudan are yet to define their strategies and develop a functional transmission and distribution 
network to attract significant solar PV investors. Generally, government initiatives are fundamental for spurring minigrid uptake, refining operation models to enhance sustainability and adequate margins is also critical before scaling up. Funding from international and national organizations will still be required in the future. Innovative measures like hybridizing old fossil fuel IPPs and power demand creation by minigrids as well as the PPP modeling of minigrids are critical for the sustainability of the minigrids.

The grid-connected solar PV minigrid and its storage applied to critical loads such as industrial and commercial loads used simulations from HOMER software to reveal that it can still contribute to affordable electricity through peak shaving, except for Tanzania because Tanzania electricity tariff is low and serving a big critical load (commercial and industrial) would have no affordability impact on the electricity tariff. For the other five member countries of the EAC, the peak shaving strategy through a solar PV minigrid and its storage reveals that it would decrease the electricity tariff (LCOE) to US $\$ 0.196 / \mathrm{kWh}$ for Burundi, US $\$ 0.151 / \mathrm{kWh}$ for Kenya, US $\$ 0.172 / \mathrm{kWh}$ for Rwanda, US\$0.210/kWh for South Sudan, and US $\$ 0.140 / \mathrm{kWh}$ for Uganda, which are much lower than the real electricity tariffs currently in use in these countries. Future studies can be considered for the feasibility of solar PV minigrids with residential loads which are not critical like industrial and commercial loads; and feasibility studies of solar PV minigrids with off-grid large scale loads (locations where the grid option is not possible). The concepts and results in this paper would be useful to power systems designers, scholars, and policy-makers in East Africa and other parts of the world with similar energy crises.

\section{Data Availability}

The data used to support the findings of this study are available from the submitting author upon request.

\section{Conflicts of Interest}

The authors declare no conflicts of interest.

\section{Acknowledgments}

The authors are grateful to Hebei Social Science Foundation major project "Hebei Province Regional Innovation-Driven Development Mechanism Construction in the New Era" (HB19ZD03), Hebei Province Innovation Capacity Enhancement Project: Research on Hebei Province Regional Innovation System Construction under the Background of BeijingTianjin-Hebei Coordinated Development (19457678D), Innovation Strategy Funded project by The Department of Science and Technology of Hebei Province: Research on the Innovative Development Mode of Characteristic Industry in Handan City (20180403), and Hebei Provincial Department of Education Humanities and Social Science Research Major Project "Research on Hebei Province's High-quality Development Mechanism Leaded by Innovative Ecosystem Development" (ZD202004).

\section{References}

[1] I. P. Da Silva, G. Ronoh, and J. Ndegwa, "Energy performance of off-grid connected solar PV systems in Kenya-case study," 2013.

[2] Bloomberg, "Lighting global,Bloomberg new energy finance, global off-grid solar market trends," 2016.

[3] World Bank, Bringing home solar systems to off-grid communities, World Bank (WB), 2017 , http:// www innovationpolicyplatform.org/.

[4] IEA, I, UNSD, World Bank, and World Health Organization, Tracking SDG 7, The Energy Progress Report 2019, Washington DC, 2019.

[5] IEA, I, UN, WB, and WHO, “TRACKING SDG 7," The Energy Progress Report, The World Bank (WB),World Health Organisation(WHO), Washington DC, IEA, IRENA,United Nations Statistics Division (UN), 2020.

[6] A. K. Aschalew Tigabu, F. H. Wandera, R. Hanlin, M. H. Andersen, and R. Lema, Capability development and collaboration for Kenya's solar and wind technologies: analysis of major energy policy frameworks, Innovation and Renewable Electrification in Kenya (IREK), Copenhagen/Nairobi/Eldoret, 2017.

[7] UN, "Transforming our world: rhe 2030 agenda for sustainable development," in Resolution adopted by the general assembly on 25th December 2015, United Nations, New York, USA, 2015.

[8] M. B. Pedersen, "Deconstructing the concept of renewable energy -based mini-grids for rural electrification in East Africa," Energy and Environment, vol. 5, no. 5, pp. 570-587, 2016.

[9] V. C. K. Kennedy Fohoue-Tchendjou, D. Tieudjo, and L. Bitjoka, "Management of hybrid renewable energy systems using differential hybrid Petri nets," TECHNIUM, vol. 2, no. 7, pp. 64-76, 2009.

[10] SEforALL, "State of the global mini-grids market 2020," in Trends of renewable energy hybrids mini-grids in Sub-saharan Africa, Asia and island nations, Sustainable Energy for All, 2020.

[11] N. Bloomberg, "State of the minigrid market report 2020," in trends of renewable energy hybrid mini-grids in Sub-Saharan Africa, Asia and island nations, Sustainable Energy for All, Mini-Grids Partnership (MGP), Bloomberg NEF, 2020.

[12] H. E. M. Rana Adib, F. Appavou, A. Brown, B. Epp, and C. Lins, Renewable energy policy network for the 21st century (REN21), Renewables 2016 Global Status Report, 2016.

[13] D. M. K. David Mozersky, South Sudan's renewable energy potential:a building block for peace, United States Institute of Peace, Washington DC, 2018.

[14] SOLARGIS, "Download solar resource maps and GIS data for 200+ countries," 2020, https://solargis.com/maps-and-gisdata/download/south-sudan/.

[15] RESP, Market Information, Africa-EU Renewable Energy Cooperation Programme, Uganda, 2018.

[16] European Union, "10 MW EU funded Tororo Solar Power Plant Opens; Delegation of the European Union to Uganda," 2017, https://eeas.europa.eu/delegations/uganda/34013/10mw-eu-funded-tororo-solar-power-plant-opens_en/.

[17] Government of Uganda, "Kabulasoke Solar Power Station to be ready in November," 2018, http://vicepresident.go.ug/ index.php/vp-news/291-kabulasoke-solar-power-stationtobe-ready-in-november/. 
[18] Tryba Energy, "The construction of a 10MWP solar power plant in Uganda is moving ahead rapidly," 2018, http:// vicepresident.go.ug/index.php/vp-newswww.tryba-energy .com/en/2018/03/30/construction-of-a-10-mwpsolar-powerplant-in-uganda-is-moving-ahead-rapidly-it-will-beconnected-to-the-grid-and-operational-at-the-endof-theyear//291-kabulasoke-solar-power-station-tobe-ready-innovember/.

[19] W. H. Jon Lane, A. Gous, and R. Kuteesa, "Mini-grid market opportunity assessment:Uganda," 2018.

[20] REA, "Rural electrification agency," 2020, http://www.rea.or .ug/.

[21] EPRA, 2020, https://www.epra.go.ke/.

[22] IEA, SDG7: data and projections, access to affordable, reliable, sustainable and modern energy for all, International Energy Agency (IEA), 2020.

[23] REA, "Rural Electrification Strategy and Plan (RESP)," 2013, http://www.rea.or.ug/resources/strategy\%20and\%20plan\% 202013-2022.pdf.

[24] K. Lee, E. Brewer, C. Christiano et al., "Electrification for "Under Grid" households in Rural Kenya," Development Engineering, vol. 1, pp. 26-35, 2016.

[25] ESMAP, Mini Grids in Kenya. A Case Study of a Market at a Turning Point, Energy Sector Management Assistance Program, 2017.

[26] International Renewable Energy Agency: IRENA, 2020, https://www.irena.org/solar/.

[27] I. P. Da Silva, G. Batte, J. Ondraczek, G. Ronoh, and C. A. Ouma, Diffusion of solar energy technologies in rural Africa, Durban, South Africa, 2014.

[28] Strathmore University, "Strathmore University and Kenya power sign solar energy purchase deal," 2015, https://www .strathmore.edu/news/strathmore-university-and-kenyapower-sign-solar-energy-purchase-deal/.

[29] GoK, "Kenya National Electrification Strategy," p. 38, 2018.

[30] Rea KP, "Kenya Off-Grid Solar Access Project (K-OSAP)," in Rural Electrification Authority (REA), Kenya Power, 2017.

[31] USAID, Off-Grid Solar Market Assessment Kenya, USAID, 2019.

[32] MoE, 2020, http://energy.go.ke/.

[33] KenGen, 2020, http://www.kengen.co.ke/.

[34] Kenya Power, 2020, http://www.kengen.co.ke//https://www .kplc.co.ke/.

[35] REREC, 2020, http://www.rerec.co.ke/.

[36] GoK, "The energy bill, 2015," in Kenya Gazette Supplement No. 134 (National Assembly Bills No. 50), Government of Kenya, 2015.

[37] GoK, "The energy (electricity licensing) regulations, 2012," 2012, https://www.epra.go.ke/download/the-energy-energymanagement-regulations-2012/.

[38] E. S. Lily Odarno, M. Swai, M. J. J. Katyega, and A. Lee, Accelerating minigrid deployment in sub-Saharan Africa lessons from Tanzania, TATEDO, World Resources Institute, 2017.

[39] Government of Tanzania, "Ministry of energy," 2020, https:// www.nishati.go.tz/en/.

[40] Government of Tanzania, "Report: Tanzania mini-grid sector doubles with bold policy approach," 2017.

[41] J. M. Takouleu, Tanzania: CBEA finances PowerGen to provide 60 solar mini-grids, Afrik21, 2019.

[42] TANESCO, “TANESCO,” 2020, http://www.tanesco.co.tz/.
[43] REA, "Rural Energy Agency (REA)," 2020, http://www.rea.go.tz/.

[44] Government of Tanzania, “The Rural Energy Act," p. 2005, 2005.

[45] IRENA, Renewables Readiness Assessment, International Renewable Energy Agency (IRENA), United Republic of Tanzania, 2017.

[46] Government of Tanzania, "The electricity (development of small power projects) rules, 2016. Electricity ACT (CAP 131)," 2016.

[47] J. Barba, The electricity sector in Burundi: a place for renewable energy in the great lakes region?, T. E. Platform, 2018.

[48] S. T. Manfred Hafner, G. Falchetta, and G. Occhiali, Countrylevel analysis: power sector, energy resources, and policy context, Springer, 2019.

[49] UNEP, "Energy profile: Burundi," 2017, https://wedocs.unep .org/handle/20.500.11822/20486/.

[50] R. Burundi, “Agence Burundaise De D'electrification Rurale (ABER),” 2020, http://www.aber.bi/indexE.php/.

[51] REEEP, “Burundi (2012)," 2012, https://www.reeep.org/ burundi-2012/.

[52] REPP, “MUBUGA; 8.67MWp solar PV power plant,” 2020, https://repp.energy/project/mubuga-burundi/.

[53] World Bank, "Solar energy in local communities," 2020, https://projects.worldbank.org/en/projects-operations/ project-detail/P164435/.

[54] SEforALL, The Republic of South Sudan, Rapid Situation Assessment and Gap Analysis Report, 2013.

[55] African Development Bank, A, "Provision for electricity and rural energy," 2013.

[56] D. Ghandour, "Struggles for electric power supply in Sudan and South Sudan," in Fifth International Conference On Advances in Economics, Management and Social Study - EMS 2016, Kuala Lumpur, Malaysia, March 2016.

[57] UNEP, “Energy profile: South Sudan,” 2017, https://wedocs .unep.org/handle/20.500.11822/20597/.

[58] E. Bellini, "South Sudan to get $20 \mathrm{MW} / 35$ MWh solar-plusstorage plant. pv magazine," 2019.

[59] S. L. Selen Kesrelioglu, Y. Ingabire, W. Rubasharaza, and I. Troconis, Rwanda Off-Grid Status Report 2018, Energising Development Rwanda, 2018.

[60] RWANDA RO, Rural Electrification Strategy, M. o. Infrastructure, 2016.

[61] Rwanda Energy Group, R, "Off Grid Electricity Access Expansion Programs in Rwanda," 2019.

[62] S. Bimenyimana, G. N. O. Asemota, and L. Li, "The state of the power sector in Rwanda:a progressive sector with ambitious targets," Frontiers in Energy Research, vol. 6, no. 68, 2018.

[63] G. Adwek, S. Boxiong, P. O. Ndolo et al., "The solar energy access in Kenya: a review focusing on Pay-As-You-Go solar home system," Environment, Development and Sustainability, vol. 22, no. 5, pp. 3897-3938, 2020.

[64] C. N. Dominic Samoita, P. A. Østergaard, and A. Remmen, "Barriers and solutions for increasing the integration of solar photovoltaic in Kenya's electricity mix," energies, vol. 13, no. 5502, 2020.

[65] S. Kesrelioglu, Rwanda Off-Grid Sector Status Report 2017, Energising Development Rwanda, 2018.

[66] Republic of Rwanda, "Regulation no. 03/R/EL-EWS/RURA/2019 governing the simplified electricity licensing framework for rural electrification in Rwanda," 2019. 
[67] USAID, Off-Grid Solar Market Assessment Rwanda, USAID, Power Africa, 2019.

[68] A. S. Paul Kirai and M. Hankins, Target Market Analysis, The Solar Energy Market in Rwanda. D. G. f. technisque, 2009.

[69] RURA, "Rwanda Utilities Regulatory Authority (RURA)," 2020, https://rura.rw/index.php?id=45/.

[70] D. C. Mary Willcox, "NAE Case Study: Tanzania, Mini-Grids Regulatory Framework," 2018, https://energypedia.info/wiki/ NAE_Case_Study:_Tanzania,_Mini-Grids_Regulatory_ Framework/.

[71] E. Gordon, "The Politics of Renewable Energy in East Africa," 2018.

[72] USAID, Off-Grid Solar Market Assessment Tanzania, USAID, Power Africa, 2019.

[73] EnDev, Rwanda: Off-Grid Sector Status 2016. Achievements in 2016 and trends for 2017, Energising Develpment (EnDev)Rwanda, 2017.

[74] ECA, Project Design Study on the Renewable Energy Development for Off-Grid Power Supply in Rural Regions of Kenya, Economic Consulting Associates', 2014.

[75] EEP, Solar PV Business Models in East Africa:Lessons Learnt from EEP Supported Projects, Energy and Environment Partnership/Southern and East Africa, 2016.

[76] A. George, S. Boxiong, M. Arowo, P. Ndolo, Chepsaigutt-Chebet, and J. Shimmon, "Review of solar energy development in Kenya: opportunities and challenges," Renewable Energy Focus, vol. 29, pp. 123-140, 2019.

[77] Practical Action, Real-time monitoring, control and payment technology for mini-grids, Rwanda field test evaluation report, 2017.

[78] IRENA, "Policies and Regulations for Private Sector Renewable Energy Mini-Grids,” 2016.

[79] S. AfDB, "Green Mini-Grids Market Development Programme," 2016. 